\title{
A Thermodynamic Investigation into Steam-Methane Reforming and the Synthesis of Methane from Carbon Monoxide and Hydrogen
}

\author{
Li-hua Wu \\ M. H. Lietzke
}

\section{MASTER}

\section{OAK RIDGE NATIONAL LABORATORY}

OPERATED BY UNION CARBIDE CORPORATION FOR THE ENERGY RESEARCH AND DEVELOPMENT ADMINISTRATION 


\section{DISCLAIMER}

Portions of this document may be illegible in electronic image products. Images are produced from the best available original document. 


\section{Printed in the United States of America. Available from National Technical Information Service \\ U.S. Department of Commerce \\ 5285 Port Royal Road, Springfield, Virginia 22161 \\ Price: Printed Copy $\$ 4.50$; Microfiche $\$ 2.25$}

This report was prepared as an account of work sponsored by the United States Government. Neither the United States nor the Energy Research and Development Administration/United States Nuclear Regulatory Commission, nor any of their employees, nor any of their contractors, subcontractors, or their employees, makes any warranty, express or implied, or assumes any legal liability or responsibility for the accuracy, completeness or usefulness of any information, apparatus, product or process disclosed, or represents that its use would not infringe privately owned rights. 
ORNL-5225

Dist. Category UC-4

Contract No. W-7405-eng-26

CHEMISTRY DIVISION

A THERMODYNAMIC INVESTIGATION INTO STEAM-METHANE REFORMING AND THE SYNTHESIS OF METHANE FROM CARBON MONOXIDE AND HYDROGEN

Li-hua Wu and M. H. Lietzke

Date Published: November 1976

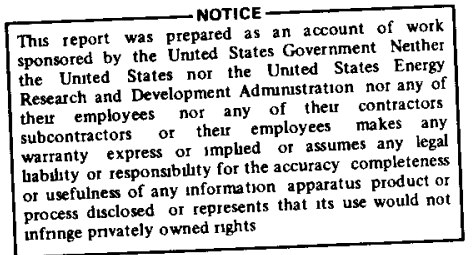

OAK RIDGE NATIONAL LABORATORY

Oak Ridge, Tennessee 37830

operated by

UNION CARB IDE CORPORATION

for the

ENERGY RESEARCH AND DEVELOPMENT ADMINISTRATION 


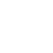


CONTENTS

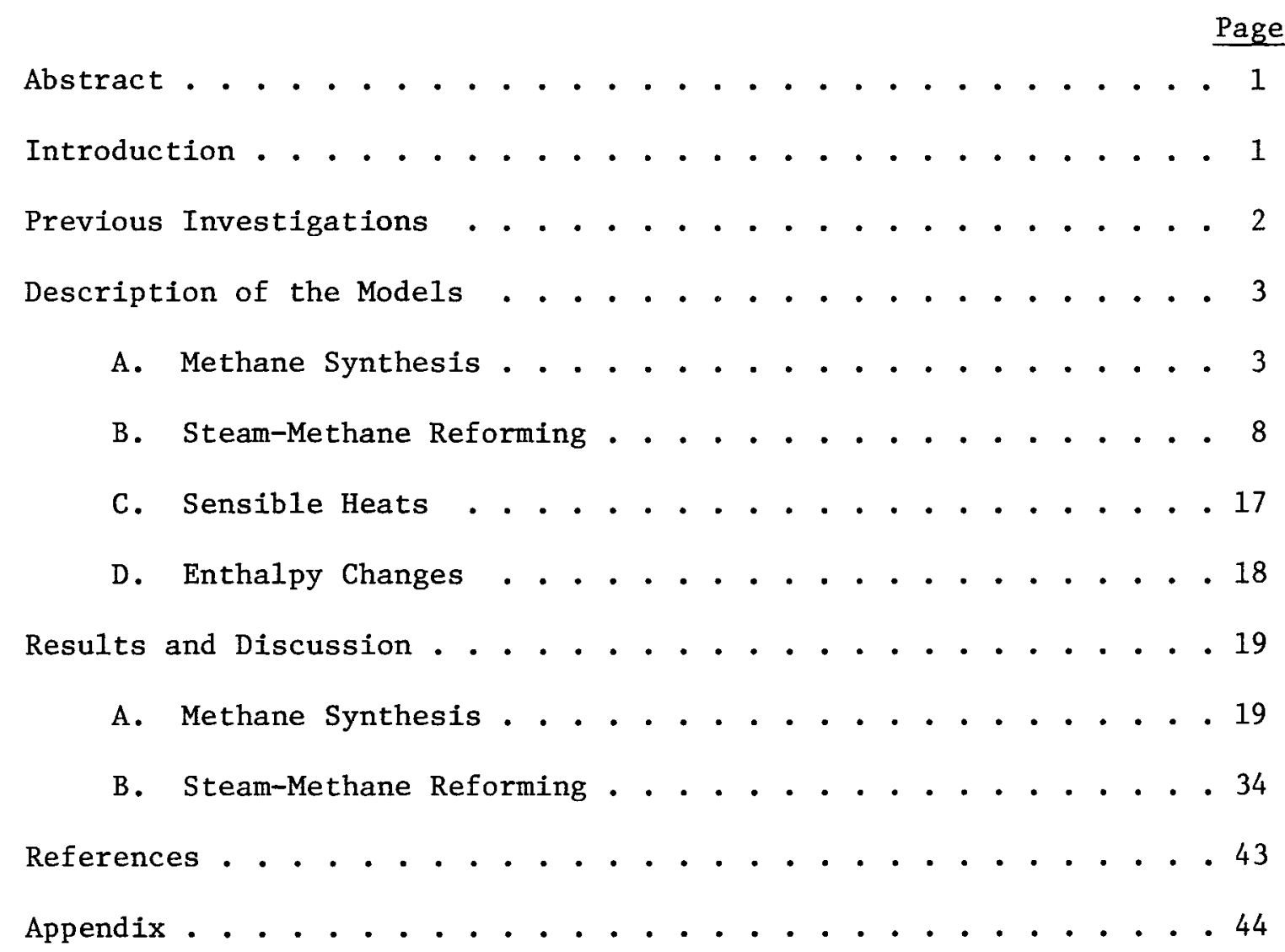


A THERMODYNAMIC INVESTIGATION INTO STEAM-METHANE REFORMING AND THE

SYNTHESIS OF METHANE FROM CARBON MONOXIDE AND HYDROGEN

Li-hua Wu and M. H. Lietzke

ABSTRACT

In this study the steam-methane equilibrium reaction was investigated by considering both methane synthesis from hydrogen and carbon monoxide and by considering steam-methane reforming from methane and steam. A FORTRAN computer program was written to carry out all the calculations over a wide range of temperatures, pressures, and initial compositions. The products of each process as a function of pressure, temperature, and starting ratio of reactant gases were calculated, as well as the heats involved. In both processes the minimum ratios above which no carbon precipitates were determined as a function of temperature and pressure.

\section{INTRODUCTION}

The steam, methane, hydrogen, carbon monoxide equilibrium has a number of interesting and important applications, since the equilibrium may be approached starting either with hydrogen and carbon monoxide or with steam and methane. The catalytic reaction between hydrogen and carbon monoxide is exothermic and may be used to synthesize methane. Moreover, by using different catalysts and operating conditions other organic compounds such as methanol may be directly synthesized in a similar manner. Experience gained in modelling the methane synthesis may be useful in investigating the synthesis of other organic compounds. The catalytic reaction between steam and methane, on the other hand, is endothermic and results in the production of a mixture of hydrogen and carbon monoxide, a process known as steam-methane reforming. One promising application of this process is to use the hydrogen-carbon monoxide mixture in the direct reduction of iron ore. Another possibility is to use the 
reaction for the chemical storage of energy, since heat must be supplied to drive the reaction. This heat may partially be recovered later by allowing the reverse exothermic reaction to take place.

In utilizing the methane-steam equilibrium system in any practical application, the formation of elemental carbon by disproportionation of carbon monoxide must be avoided. Carbon formed in this way causes catalyst inactivation as well as plugging and fouling of equipment. Hence it is necessary to define the range of operating conditions under which no deposition of carbon occurs. In this study we have considered the effects of temperature, pressure, and initial compositions on final yields both for the synthesis of methane and for steam-methane reforming. Detailed models of both of these processes have been developed and a computer program written to carry out the calculations. Provision is made in the program for the deposition of carbon either as B-graphite or as "Dent" carbon. ${ }^{1}$ "Dent" carbon has apparently not been characterized except that it is a non-graphite form of carbon. The conditions favoring either B-graphite or "Dent" carbon precipitation are not known. However, equilibrium constants as a function of temperature are available for the disproportionation of carbon monoxide to yield either $\beta$-graphite or "Dent" carbon. In general, when "Dent" carbon is precipitated, the mole fraction of carbon is lower than when B-graphite is precipitated.

\section{PREVIOUS INVESTIGATIONS}

The synthesis of methane has previously been investigated by M. Greyson and co-workers ${ }^{2}$ for the temperature range $500-900^{\circ} \mathrm{K}$, for pressures of 1,10 , and 25 atmospheres and for hydrogen-carbon monoxide 
3

ratios from 0.50 to the limiting ratio above which the deposition of carbon does not occur. These authors did not have the benefit of a modern high speed computer and hence did not make as complete a study as that reported in the present work. They did not compute any sensible heats.

Gruber $^{3 a}$ also studied the methane synthesis system and considered that carbon may be deposited either as graphite or as "Dent" carbon. ${ }^{1}$ In this work all possible starting compositions are considered over a temperature range of $600^{\circ} \mathrm{K}$ and $2000^{\circ} \mathrm{K}$ and a pressure range of $30 \mathrm{~atm}$ to $300 \mathrm{~atm}$. Again no sensible heats were computed and the results of the calculations are presented graphically in a way that is not easy to interpret.

$P$. Wellman and S. Kate $11^{4}$ studied the effect of pressure and temperature on steam-methane reforming over a temperature range of $1200^{\circ} \mathrm{F}$ to $1900^{\circ} \mathrm{F}$, a pressure range of 5 to 31 atmospheres, and a steam-to-methane ratio range of 2 to 6 . However, they did not consider the deposition of carbon in their calculations.

\section{DESCRIPTION OF THE MODELS}

The discussion of the methane-steam equilibrium will be broken into two parts. The first part will deal with the synthesis of methane from carbon monoxide and hydrogen, while the second part will deal with the reforming of methane by steam to produce hydrogen and carbon monoxide.

\section{A. Methane Synthesis}

In considering the synthesis of methane from hydrogen and carbon monoxide, the following reactions are sufficient to describe the system: 


$$
\begin{aligned}
& 3 \mathrm{H}_{2}+\mathrm{CO} \stackrel{\leftarrow}{\rightarrow} \mathrm{CH}_{4}+\mathrm{H}_{2} \mathrm{O} \\
& \mathrm{CO}+\mathrm{H}_{2} \mathrm{O} \stackrel{\leftarrow}{\rightarrow} \mathrm{CO}_{2}+\mathrm{H}_{2} \\
& 2 \mathrm{CO} \stackrel{\leftarrow}{\rightarrow} \mathrm{C}(\mathrm{s})
\end{aligned}
$$

Let the initial mole fractions of $\mathrm{H}_{2}$ and $\mathrm{CO}$ be $\underline{\mathrm{a}}$ and 1 - $\underline{\mathrm{a}}$, respectively, and the final yields of $\mathrm{CH}_{4}, \mathrm{CO}_{2}$, and $\mathrm{C}$ be $\underline{x}, \underline{y}$, and $\underline{z}$ moles per mole input. From the equilibrium relationships of Eqs. (1) to (3), the final moles of $\mathrm{H}_{2} \mathrm{O}, \mathrm{H}_{2}$, and $\mathrm{CO}$ can be expressed in terms of a , $\underline{x}, \underline{y}$, and $\underline{z}$ as

$$
\begin{aligned}
& \mathrm{H}_{2} \mathrm{O}=\mathrm{x}-\mathrm{y}+\mathrm{z}, \\
& \mathrm{H}_{2}=\mathrm{a}-3 \mathrm{x}+\mathrm{y}-\mathrm{z}, \\
& \mathrm{CO}=1-\mathrm{a}-\mathrm{x}-\mathrm{y}-\mathrm{z} .
\end{aligned}
$$

The total number of moles of gas is then $1-2 \underline{x}-\underline{z}$. Thus, the equilibrium constants for Eqs. (1) through (3) may be written as

$$
\begin{aligned}
\mathrm{K}_{\mathrm{p}, 1} & =\frac{\mathrm{p}_{\mathrm{CH}_{4}} \cdot \mathrm{p}_{\mathrm{H}_{2} \mathrm{O}}}{\mathrm{p}_{\mathrm{H}_{2}}^{3} \cdot \mathrm{p}_{\mathrm{CO}}} \\
& =\frac{\frac{\mathrm{x}}{1-2 \mathrm{x}-\mathrm{z} \cdot \frac{\mathrm{x}-\mathrm{y}+\mathrm{z}}{1-2 \mathrm{x}-\mathrm{z}} \mathrm{p}}}{\frac{(\mathrm{a}-3 \mathrm{x}+\mathrm{y}-\mathrm{z})^{3}}{(1-2 \mathrm{x}-\mathrm{z})^{3}} \cdot \frac{1-\mathrm{a}-\mathrm{x}-\mathrm{y}-\mathrm{z}}{1-2 \mathrm{x}-\mathrm{z}} \mathrm{p}} \\
& =\frac{\mathrm{x}(\mathrm{x}-\mathrm{y}+\mathrm{z})(1-2 \mathrm{x}-\mathrm{z})^{2}}{(\mathrm{a}-3 \mathrm{x}+\mathrm{y}-\mathrm{z})^{3}(1-\mathrm{a}-\mathrm{x}-\mathrm{y}-\mathrm{z}) \mathrm{p}^{2}},
\end{aligned}
$$




$$
\begin{aligned}
& \mathrm{k}_{\mathrm{p}, 2}=\frac{\mathrm{p}_{\mathrm{CO}_{2}} \cdot \mathrm{p}_{\mathrm{H}_{2}}}{\mathrm{p}_{\mathrm{CO}} \cdot \mathrm{p}_{\mathrm{H}_{2} \mathrm{O}}} \\
& =\frac{\frac{y}{1-2 x-z} p \cdot \frac{a-3 x+y-z}{1-2 x-z} p}{\frac{1-a-x-y-z}{1-2 x-z} p \cdot \frac{x-y+z}{1-2 x-z} p} \\
& =\frac{y(a-3 x+y-z)}{(1-a-x-y-z)(x-y+z)} \text {, } \\
& \mathrm{k}_{\mathrm{p}, 3}=\frac{\mathrm{p}_{\mathrm{CO}}}{\mathrm{p}_{\mathrm{CO}}^{2}} \\
& =\frac{\frac{y}{1-2 x-z} p}{\frac{(1-a-x-y-z)^{2}}{(1-2 x-z)^{2}} p^{2}} \\
& =\frac{y(1-2 x-z)}{(1-a-x-y-z)^{2} p},
\end{aligned}
$$

where $\underline{p}_{i}$ is the partial pressure of component $\underline{i}$, and $p$ is the total pressure of the system. Values of the logarithms of these constants were calculated at a number of temperatures using thermodynamic data from the literature. ${ }^{5}$ These values were then fitted by the method of least squares to yield the following expressions.

$$
\begin{aligned}
\log k_{p, 1}= & 2.15530 \times 10-3.33134 \times 10^{-2} t+1.59845 \times 10^{-5} t^{2} \\
& -2.94297 \times 10^{-9} t^{3} \\
\log k_{p, 2}= & 4.09775-5.89713 \times 10^{-3} t+2.90724 \times 10^{-6} t^{2} \\
& -5.33920 \times 10^{-10} t^{3}
\end{aligned}
$$




$$
\begin{aligned}
\log \mathrm{K}_{\mathrm{p}, 3}= & 1.72556 \times 10-2.51018 \times 10^{-2} \mathrm{t}+1.18293 \times 10^{-5} \mathrm{t}^{2} \\
& -2.12805 \times 10^{-9} \mathrm{t}^{3}
\end{aligned}
$$

while for "Dent" carbon $3 b$

$$
\begin{aligned}
\log \mathrm{K}_{\mathrm{p}, 3}= & 3.35280+8.36512 \times 10^{-3} \mathrm{t}-1.63599 \times 10^{-5} \mathrm{t}^{2} \\
& +6.05889 \times 10^{-9} \mathrm{t}^{3} .
\end{aligned}
$$

In these equations $\underline{t}$ refers to the temperature expressed in degrees Fahrenheit.

Thus, for each temperature, pressure, and value of a , equations (1) through (3) must be solved simultaneously to yield values of the three unknowns $\underline{x}, \underline{y}$, and $\underline{z}$. This calculation is conventiently carried out using the first-order Newton-Raphson method. ${ }^{6}$ First we define three functions

$$
\begin{aligned}
& f_{1}(x, y, z), f_{2}(x, y, z) \text {, and } f_{3}(x, y, z) \text { as } \\
& f_{1}(x, y, z)=k_{p, I}(a-3 x+y-z)^{3}(1-a-x-y-z) p^{2} \\
& -x(x-y+z)(1-2 x-z)^{2} \\
& f_{2}\left(x, y, z=k_{p, 2}(1-a-x-z)(x-y+z)\right. \\
& -y(a-3 x+y-z) \\
& f_{3}(x, y, z)=k_{p, 3}(1-a-x-y-z)^{2} p-y(1-2 x-z) .
\end{aligned}
$$

The derivatives of these functions with respect to $\underline{x}, \underline{y}$, and $\underline{z}$ are given by

$$
\begin{aligned}
\frac{\partial f_{1}}{\partial x}= & -9 K_{p, 1}(a-3 x+y-z)^{2}(1-a-x-y-z) p^{2} \\
& -k_{p, 1}(a-3 x+y-z)^{3} p^{2}-(x-y+z)(1-2 x-z)^{2} \\
& -x(1-2 x-z)^{2}+4 x(x-y+z)(1-2 x-z)
\end{aligned}
$$




$$
\begin{aligned}
\frac{\partial f_{1}}{\partial y}= & 3 k_{p, 1}(a-3 x+y-z)^{2}(1-a-x-y-z) p^{2} \\
& -k_{p, 1}(a-3 x+y-z)^{3} p^{2}+x(1-2 x-z)^{2}
\end{aligned}
$$

$$
\begin{aligned}
\frac{\partial f_{1}}{\partial z}= & -3 k_{p, 1}(a-3 x+y-z)^{2}(1-a-x-y-z) p^{2} \\
& -k_{p, 1}(a-3 x+y-z)^{3} p^{2}-x(1-2 x-z)^{2} \\
& +2 x(x-y+z)(1-2 x-z)
\end{aligned}
$$

$$
\begin{aligned}
\frac{\partial f_{2}}{\partial x}= & -k_{p, 2}(x-y+z)+K_{p, 2}(1-a-x-y-z)+3 y \\
\frac{\partial f_{2}}{\partial y}= & -K_{p, 2}(x-y+z)-K_{p, 2}(1-a-x-y-z) \\
& -(a-3 x+y-z)-y
\end{aligned}
$$

$$
\frac{\partial f_{2}}{\partial z}=-k_{p, 2}(x-y+z)+K_{p, 2}(1-a-x-y-z)+y
$$$$
\frac{\partial \mathbf{f}_{3}}{\partial x}=-2 k_{p, 3}(1-a-x-y-z) p+2 y
$$$$
\frac{\partial f_{3}}{\partial y}=-2 K_{p, 3}(1-a-x-y-z) p-(1-2 x-z)
$$$$
\frac{\partial f_{3}}{\partial z}=-2 K_{p, 3}(1-a-x-y-z) p+y
$$

Hence, in starting the calculations, for each initial set of guesses $\underline{x}, \underline{y}$, and $\underline{z}$ we can obtain another set of values $\alpha, \beta$, and $\gamma$ by using the equations:

$$
\begin{aligned}
\mathrm{f}_{i}(\alpha, \beta, \gamma)= & \mathrm{f}_{\mathbf{i}}(\mathrm{x}, \mathrm{y}, z)+(\alpha-\mathrm{x}) \frac{\partial \mathrm{f}_{i}}{\partial \mathrm{x}}+(\beta-\mathrm{y}) \frac{\partial \mathrm{f}_{i}}{\partial \mathrm{y}} \\
& +(\gamma-z) \frac{\partial \mathrm{f}_{i}}{\partial z}
\end{aligned}
$$


where $\underline{i}=1,2,3$. Equation (26) can be written in matrix form as

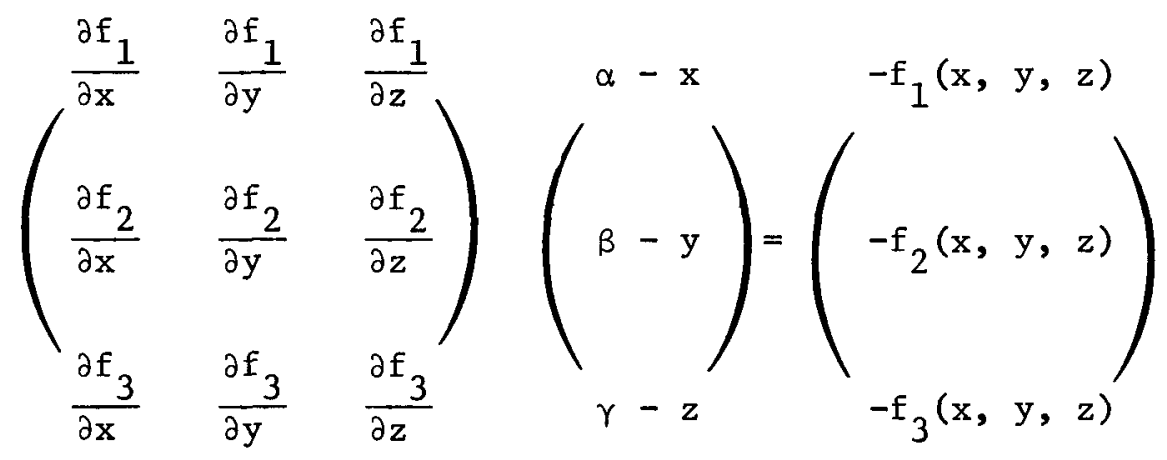

The inverse of the $3 \times 3$ matrix in Eq. (27) may be obtained by using the Gauss-Jordan method. ${ }^{7}$ Pre-multiplying both sides of Eq. (27) by the inverse matrix we get $\alpha, \beta$, and $\gamma$, which are equated to $\underline{x}, \underline{y}$, and $\underline{z}$, respectively. The procedure is repeated until the differences between two sets of values are smaller than some pre-defined criterion value (in our case $1 \times 10^{-5}$ ).

If $\gamma$ happens to be zero for a given set of conditions, i.e., if no carbon precipitation is indicated, then equation (3) is dropped and $\underline{z}$ is removed from all the terms in equations (1) and (2). Consequently equation (27) is reduced to

$$
\left(\begin{array}{cc}
\frac{\partial f_{1}}{\partial x} & \frac{\partial f_{1}}{\partial y} \\
\frac{\partial f_{2}}{\partial x} & \frac{\partial f_{2}}{\partial y}
\end{array}\right)\left(\begin{array}{c}
\alpha-x \\
\beta-y
\end{array}\right)=\left(\begin{array}{l}
-f_{1}(x, y) \\
-f_{2}(x, y)
\end{array}\right)
$$

B. Steam-Methane Reforming

In considering the steam-methane reforming process, the following reactions are sufficient to describe the system: 


$$
\begin{aligned}
& \mathrm{H}_{2} \mathrm{O}+\mathrm{CH}_{4} \rightleftarrows \mathrm{CO}+3 \mathrm{H}_{2} \\
& \mathrm{CO}+\mathrm{H}_{2} \mathrm{O} \stackrel{\rightleftarrows}{\leftarrow} \mathrm{CO}_{2}+\mathrm{H}_{2} \\
& 2 \mathrm{CO} \stackrel{\rightarrow}{\mathrm{C}}(\mathrm{s})
\end{aligned}
$$

In this model the first equation ( $1^{\prime}$ ) is just the inverse of Eq. (1), while the other two equations are the same as in the methane synthesis model. Let the initial mole fractions of steam and methane be a and 1 - $\underline{a}$, and let $\underline{x}$ represent the number of moles of methane reacted. Further let $\underline{y}$ and $\underline{z}$ be the final yields of $\mathrm{CO}_{2}$ and $\mathrm{C}$ per mole input, respectively. From the equilibrium relationships of Eqs. (1) to (3), the final moles of $\mathrm{H}_{2} \mathrm{O}, \mathrm{CH}_{4}, \mathrm{CO}$, and $\mathrm{H}_{2}$ can then be expressed in terms of $\underline{a}, \underline{x}, \underline{y}$, and $\underline{z}$ as

$$
\begin{aligned}
\mathrm{H}_{2} \mathrm{O} & =\mathrm{a}-\mathrm{x}-\mathrm{y}+\mathrm{z} \\
\mathrm{CH}_{4} & =1-\mathrm{a}-\mathrm{x} \\
\mathrm{CO} & =\mathrm{x}-\mathrm{y}-\mathrm{z} \\
\mathrm{H}_{2} & =3 \mathrm{x}+\mathrm{y}-\mathrm{z} .
\end{aligned}
$$

The total number of moles of gas is then $1+2 \underline{x}-\underline{z}$. Thus, the equilibrium constants of reactions (1) to (3) may be written as

$$
\begin{aligned}
\mathrm{K}_{\mathrm{p}, 1}= & \frac{\mathrm{p}_{\mathrm{CO}} \cdot \mathrm{p}_{\mathrm{H}_{2}}^{3}}{\mathrm{p}_{\mathrm{H}_{2} \mathrm{O}} \cdot \mathrm{p}_{\mathrm{CH}_{4}}} \\
= & \frac{\frac{\mathrm{x}-\mathrm{y}-\mathrm{z}}{1+2 x-z} \cdot \frac{(3 x+y-z)^{3}}{\mathrm{a}-\mathrm{x}-\mathrm{y}+\mathrm{z}} \mathrm{p}^{3}}{\frac{(1+2 x-z)^{3}}{1+2 x-z} \mathrm{p} \cdot \frac{1-\mathrm{x}-\mathrm{z}}{1+2 \mathrm{x}-\mathrm{z}}}
\end{aligned}
$$




$$
\begin{aligned}
& =\frac{(x-y-z)(3 x+y-z)^{3} p^{2}}{(a-x-y+z)(1-a-x)(1+2 x-z)^{2}} \\
& \mathrm{~K}_{\mathrm{p}, 2}=\frac{\mathrm{p}_{\mathrm{CO}_{2}} \cdot \mathrm{p}_{\mathrm{H}_{2}}}{\mathrm{p}_{\mathrm{CO}} \cdot \mathrm{p}_{\mathrm{H}_{2} \mathrm{O}}} \\
& =\frac{\frac{y}{1+2 x-z} p \cdot \frac{3 x+y-z}{1+2 x-z} p}{\frac{x-y-z}{1+2 x-z} p \cdot \frac{a-x-y+z}{1+2 x-z} p} \\
& =\frac{y(3 x+y-z)}{(x-y-z)(a-x-y+z)} \\
& \mathrm{k}_{\mathrm{p}, 3}=\frac{\mathrm{P}_{\mathrm{CO}}}{\mathrm{p}_{\mathrm{CO}}^{2}} \\
& =\frac{\frac{y}{1+2 x-z} p}{\frac{(x-y-z)^{2}}{(1+2 x-z)^{2}} p^{2}} \\
& =\frac{y(1+2 x-z)}{(x-y-z)^{2} p}
\end{aligned}
$$

In these expressions $p_{i}$ is the partial pressure of the component $i$ and p is the total pressure of the system.

As in the case of methane synthesis the equilibrium constants are functions of temperature and have been calculated from the same equations used in that system except that $\log \mathrm{K}_{\mathrm{p}, 1}=-\log \mathrm{K}_{\mathrm{p}, 1}$ as given by Eq. (10).

The method of calculation is similar to that used in the methane synthesis. For each temperature and pressure we have three equations ( $1^{\prime}$ ) to (3), and three unknowns, $\underline{x}, y$, and $\underline{z}$. These are solved by the first- 
order Newton-Raphson method. We define $f_{1}(x, y, z), f_{2}(x, y, z)$, and $f_{3}(x, y, z)$ as

$$
\begin{aligned}
f_{1}(x, y, z)= & K_{p, 1}(a-x-y+z)(1-a-x)(1+2 x-z)^{2} \\
& -(x-y-z)(3 x+y-z)^{3} p^{2} \\
f_{2}(x, y, z)= & k_{p, 2}(x-y-z)(a-x-y+z) \\
& -y(3 x+y-z) \\
f_{3}(x, y, z)= & k_{p, 3}(x-y-z)^{2} p-y(1+2 x-z) .
\end{aligned}
$$

The derivatives of these functions with respect to $\underline{x}, \underline{y}$, and $\underline{z}$ are

$$
\begin{aligned}
\frac{\partial f_{1}}{\partial x}=- & k_{p, 1}(1-a-x)(1+2 x-z)^{2}-k_{p, 1}(a-x-y+z) \\
& (1+2 x-z)^{2}+4 k_{p, 1}(a-x-y+z)(1-a-x) \\
& (1+2 x-z)-(3 x+y-z)^{3} p^{2}-9(x-y-z) \\
& (3 x+y-z)^{2} p^{2}
\end{aligned}
$$

$$
\begin{aligned}
\frac{\partial f_{1}}{\partial y}= & -k_{p, 1}(1-a-x)(1+2 x-z)^{2}+(3 x+y-z)^{3} p^{2} \\
& -3(x-y-z)(3 x+y-z)^{2} p^{2}
\end{aligned}
$$

$$
\begin{aligned}
\frac{\partial f_{1}}{\partial z}= & k_{p, 1}(1-a-x)(1+2 x-z)^{2}-2 k_{p, 1}(1-a-x) \\
& (a-x-y+z)(1+2 x-z)+(3 x+y-z)^{3} p^{2} \\
+ & 3(x-y-z)(3 x+y-z)^{2} p^{2}
\end{aligned}
$$

$$
\frac{\partial f_{2}}{\partial x}=K_{p, 2}(a-x-y+z)-K_{p, 2}(x-y-z)-3 y
$$




$$
\begin{aligned}
\frac{\partial f_{2}}{\partial y}= & -k_{p, 2}(a-x-y+z)-k_{p, 2}(x-y-z) \\
& -(3 x+y-z)-y \\
\frac{\partial f_{2}}{\partial z}= & -k_{p, 2}(a-x-y+z)+k_{p, 2}(x-y-z)+y \\
\frac{\partial f_{3}}{\partial x}= & 2 k_{p, 3}(x-y-z) p-2 y \\
\frac{\partial f_{3}}{\partial y}= & -2 k_{p, 3}(x-y-z) p-(1+2 x-z) \\
\frac{\partial f_{3}}{\partial z}= & -2 k_{p, 3}(x-y-z) p+y
\end{aligned}
$$

For each initial set of guesses, $\underline{x}, \underline{y}$, and $\underline{z}$ we can get another set of values $\alpha, \beta$, and $\gamma$ by using the equations:

$$
\begin{aligned}
\mathrm{f}_{1}(\alpha, \beta, \gamma)= & \mathrm{f}_{\mathbf{i}}(\mathrm{x}, \mathrm{y}, \mathrm{z})+(\alpha-\mathrm{x}) \frac{\partial \mathrm{f}_{\mathbf{i}}}{\partial \mathrm{x}}+(\beta-\mathrm{y}) \frac{\partial \mathrm{f}_{\mathbf{i}}}{\partial \mathrm{y}} \\
& +(\gamma-z) \frac{\partial \mathrm{f}_{\mathbf{i}}}{\partial z}
\end{aligned}
$$

where $\underline{i}=1,2,3$. Equation (48) can be written in matrix form as

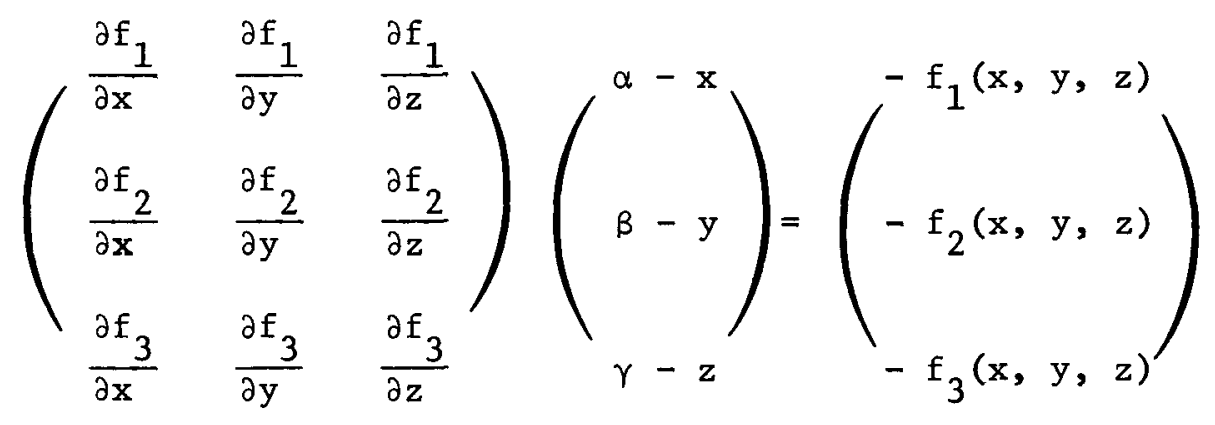

and solved by pre-multiplying both sides by the inverse of the $3 \times 3$ matrix. $\alpha, \beta$, and $\gamma$ are then equated to $\underline{x}, \underline{y}$, and $\underline{z}$, respectively. The procedure is repeated until the differences between two successive sets of values are smaller than $10^{-5}$. 
As in the case of methane synthesis, Eq. (49) reduces to

$$
\left(\begin{array}{cc}
\frac{\partial f_{1}}{\partial x} & \frac{\partial f_{1}}{\partial y} \\
\frac{\partial f_{2}}{\partial x} & \frac{\partial f_{2}}{\partial y}
\end{array}\right)\left(\begin{array}{l}
\alpha-x \\
\beta-y
\end{array}\right)=\left(\begin{array}{l}
-f_{1}(x, y) \\
-f_{2}(x, y)
\end{array}\right)
$$

if $\gamma$ equals zero for a particular set of conditions.

If the purpose of steam-methane reforming is to produce a mixture of carbon monoxide and hydrogen to be used in the direct reduction of iron ore, then the exit gases from the reformer are used directly. However, if the purpose is to produce hydrogen, e.g., for ammonia synthesis, then the exit gases from the reformer are passed through a heat exchanger and cooled to about $750^{\circ} \mathrm{F}$. The gaseous mixture then passes into a shift converter where only reactions (2) and (3) may occur (reaction (1) is favored only at high temperatures). Thus, in the shift converter additional hydrogen is produced through reaction (2). The equations to be solved are

$$
\begin{aligned}
& \mathrm{CO}+\mathrm{H}_{2} \mathrm{O} \neq \mathrm{CO}_{2}+\mathrm{H}_{2} \\
& 2 \mathrm{CO} \rightleftarrows \mathrm{C}_{(\mathrm{s})}+\mathrm{CO}_{2}
\end{aligned}
$$

Let the initial number of moles of gaseous $\mathrm{H}_{2} \mathrm{O}, \mathrm{CO}, \mathrm{H}_{2}$ and $\mathrm{CO}_{2}$ be a, $\underline{b}, \underline{c}, \underline{d}$, and $\underline{e}$, respectively, and the final yields of $\mathrm{CO}_{2}$ and $\mathrm{c}_{(\mathrm{s})}$ be $\underline{y}$ and $\underline{z}$. From the equilibrium relationships of Eqs. (1) and (2), the final number of moles of $\mathrm{H}_{2} \mathrm{O}, \mathrm{CH}_{4}, \mathrm{CO}$, and $\mathrm{H}_{2}$ may be expressed in terms of $\underline{a}, \underline{b}, \underline{c}, \underline{d}, \underline{e}, \underline{y}$, and $\underline{z}$ as

$$
\begin{aligned}
& \mathrm{H}_{2} \mathrm{O}=\mathrm{a}-\mathrm{y}+\mathrm{e}+\mathrm{z} \\
& \mathrm{CH}_{4}=\mathrm{b}
\end{aligned}
$$




$$
\begin{aligned}
& \mathrm{CO}=\mathrm{c}-\mathrm{y}+\mathrm{e}-\mathrm{z} \\
& \mathrm{H}_{2}=\mathrm{d}+\mathrm{y}-\mathrm{e}-\mathrm{z} .
\end{aligned}
$$

The total number of moles of gas is then $\underline{a}+\underline{b}+\underline{c}+\underline{d}+\underline{e}-\underline{z}$, designated TMG. Thus, the equilibrium constants of Eqs. (2) and (3) may be written as

$$
\begin{aligned}
& \mathrm{K}_{\mathrm{p}, 2}=\frac{\mathrm{p}_{\mathrm{CO}_{2}} \cdot \mathrm{p}_{\mathrm{H}_{2}}}{\mathrm{p}_{\mathrm{CO}} \cdot \mathrm{p}_{\mathrm{H}_{2} \mathrm{O}}} \\
& =\frac{\frac{y}{T M G} p \cdot \frac{d+y-e-z}{T M G} p}{\frac{c-y+e-z}{T M G} p \cdot \frac{a-y+e+z}{T M G}} p \\
& =\frac{y(d+y-e-z)}{(c-y+e-z)(a-y+e+z)} \\
& \mathrm{K}_{\mathrm{p}, 3}=\frac{\mathrm{p}_{\mathrm{CO}_{2}}}{\mathrm{p}_{\mathrm{CO}}^{2}} \\
& =\frac{\frac{y}{T M G} p}{\frac{(c-y+e-z)^{2}}{(T M G)^{2}} p^{2}} \\
& =\frac{y \cdot T M G}{(c-y+e-z)^{2} p}=\frac{y(a+b+c+d+e-z}{(c-y+e-z)^{2} p}
\end{aligned}
$$

where $p_{i}$ is the partial pressure of the component $\underline{i}$, and $p$ is the total pressure of the system. Temperature dependence of the equilibrium constants is given by Eqs. (11) and (12).

For each temperature and pressure there are thus two equations, Eqs. (55) and (56), and two unknowns, $\underline{Y}$ and $\underline{z}$. These are again solved 
by the first-order Newton-Raphson method. We define two functions

$$
\begin{aligned}
& f_{2}(y, z) \text { and } f_{3}(y, z) \text { as } \\
& \begin{aligned}
f_{2}(y, z)= & K_{p, 2}(c-y+e-z)(a-y+e+z) \\
& -y(d+y-e-z) \\
f_{3}(y, z)= & K_{p, 3}(c-y+e-z)^{2} p \\
& -y(a+b+c+d+e-z) .
\end{aligned}
\end{aligned}
$$

The derivatives of these functions with respect to $y$ and $\underline{z}$ are

$$
\begin{aligned}
\frac{\partial f_{2}}{\partial y}= & -k_{p, 2}(a-y+e+z)-k_{p, 2}(c-y+e-z) \\
& -(d+y-e-z)-y \\
\frac{\partial f_{2}}{\partial z}= & -k_{p, 2}(a-y+e+z)+k_{p, 2}(c-y+e-z)+y \\
\frac{\partial f_{3}}{\partial y}= & -2 k_{p, 3}(c-y+e-z) p-(a+b+c+d+e-z) \\
\frac{\partial f_{3}}{\partial z}= & -2 k_{p, 3}(c-y+e-z) p+y .
\end{aligned}
$$

Let the initial value of $y$ be $\underline{e}$, and $\underline{z}$ be the same as the initial guess $\underline{z}$ in the reforming calculation. We can get another set of values $\beta$ and $\gamma$ by using the equations:

$$
f_{i}(\beta, \gamma)=f_{i}(y, z)+(\beta-y) \frac{\partial f_{i}}{\partial y}+(\gamma-z) \frac{\partial f_{i}}{\partial z}
$$

where $\underline{i}=2,3$. Equation (63) may be written in matrix form as 


$$
\left(\begin{array}{cc}
\frac{\partial f_{2}}{\partial y} & \frac{\partial f_{2}}{\partial z} \\
\frac{\partial f_{3}}{\partial y} & \frac{\partial f_{3}}{\partial z}
\end{array}\right)\left(\begin{array}{l}
\beta-y \\
\gamma-z
\end{array}\right)=\left(\begin{array}{l}
-f_{2}(y, z) \\
-f_{3}(y, z)
\end{array}\right),
$$

and solved by pre-multiplying both sides of Eq. (64) by the inverse of the $2 \times 2$ matrix. $\beta$ and $\gamma$ are then equated with $\underline{y}$ and $\underline{z}$ and the procedure is repeated until the differences between two successive sets of values are smaller than $10^{-5}$.

If $\gamma$ happens to be zero, we can neglect Eq. (3) and consider Eq. (2) only. In this case let $\underline{x}$ be the number of moles of $\mathrm{CO}$ and $\mathrm{H}_{2} \mathrm{O}$ reacted and rewrite the number of moles of $\mathrm{CO}, \mathrm{H}_{2} \mathrm{O}, \mathrm{CO}_{2}$, and $\mathrm{H}_{2}$ as $\underline{c}-\underline{x}$, a $-\underline{x}$, $\underline{e}+\underline{z}$, and $\underline{\mathrm{d}}+\underline{\mathrm{x}}$, respectively. $\mathrm{K}_{\mathrm{p}, 2}$ then becomes

$$
K_{p, 2}=\frac{(e+x)(d+x)}{(c-x)(a-x)}
$$

Equation (65) can be rearranged as

$$
\begin{gathered}
\left(K_{p, 2}-1\right) x^{2}-\left(K_{p, 2} a+K_{p, 2} c+d+e\right) x \\
+\left(K_{p, 2} a c-d e\right)=0 .
\end{gathered}
$$

To solve equation (66) by the quadratic formula let $A=\left(K_{p, 2}-1\right)$,

$$
\begin{gathered}
B=\left(K_{p, 2} a+K_{p, 2} c+d+e\right), \text { and } C=\left(K_{p, 2} a c-d e\right) . \text { Then } \\
A x^{2}-B x+c=0
\end{gathered}
$$

Hence

$$
x=\frac{B \pm \sqrt{B}-4 A C}{2 A}
$$


In addition to calculating for a given set of conditions the equilibrium amounts of products formed in methane synthesis and steammethane reforming it is of interest to calculate the heat effects involved in both processes. These include the sensible heats involved in heating the reactants to the temperature of operation and cooling the products to ambient temperature, as well as the enthalpies of reaction. The calculation of these quantities is described in the next two sections.

\section{Sensible Heats}

The sensible heat of a substance $\underline{i}$ over a temperature range $\underline{t}_{1}$ to $t_{2}\left({ }^{\circ} \mathrm{F}\right)$ is defined as

$$
\mathrm{SH}_{i}=\int_{\mathrm{t}_{1}}^{\mathrm{t}} \mathrm{C}_{\mathrm{p}_{1}} \mathrm{dt}
$$

where $\mathrm{C}_{\mathrm{p}_{i}}$ is the heat capacity of the substance $\underline{i}$ at constant pressure. Values of $C_{p}$ as a function of temperature were taken from JANAF $^{5}$ for each of the substances involved in the methane-steam equilibrium and fitted by the method of least squares to equations of the form

$$
c_{p_{i}}=a_{i}+b_{i} t+c_{i} t^{-2}
$$

Expressions for the $\mathrm{SH}_{i}$ were then obtained by substituting equation (69) into equation (68) and integrating. Hence,

$$
\mathrm{SH}_{i}=a_{i}\left(t_{2}-t_{1}\right)+\frac{b_{i}}{2}\left(t_{2}^{2}-t_{1}^{2}\right)-c_{i}\left(\frac{1}{t_{2}}-\frac{1}{t_{1}}\right)
$$

In Table I are listed the parameters for equation (70) for the substances involved in the methane-steam equilibrium. The units of the $\mathrm{SH}_{i}$ are B.t.u/1b-mole. 
TABLE I

PARAMETERS OF EQUATION (70) FOR THE SENSIBLE HEATS

\begin{tabular}{cccc}
\hline Substances & \multicolumn{1}{c}{$\mathrm{a}_{i}$} & $\mathrm{~b}_{i}$ & $\mathrm{c}_{i}$ \\
\hline $\mathrm{CH}_{4}$ & 9.03446 & $5.82421 \times 10^{-3}$ & $-6.16646 \times 10^{3}$ \\
$\mathrm{H}_{2} \mathrm{O}$ & 7.66867 & $1.63605 \times 10^{-3}$ & $1.39796 \times 10^{3}$ \\
$\mathrm{CO}$ & 6.81334 & $7.95847 \times 10^{-4}$ & $5.17239 \times 10^{2}$ \\
$\mathrm{H}_{2}$ & 6.76470 & $3.65184 \times 10^{-4}$ & $6.47006 \times 10^{2}$ \\
$\mathrm{CO}_{2}$ & $1.00888 \times 10$ & $2.03493 \times 10^{-3}$ & $-8.45673 \times 10^{3}$ \\
\hline
\end{tabular}

D. Enthalpy Changes

1. Methane Synthesis

Let $\underline{a}$ and 1 - $\underline{a}$ be the initial mole fractions of $\mathrm{H}_{2}$ and $\mathrm{CO}$ input to the reactor, and let the final yields of $\mathrm{CH}_{4}, \mathrm{H}_{2} \mathrm{O}, \mathrm{CO}$ and $\mathrm{CO}_{2}$ be $\mathrm{CH}_{4}, \mathrm{H}_{2} \mathrm{O}$, $\mathrm{CO}$, and $\mathrm{CO}_{2}$ moles per mole input, respectively. Then, the enthalpy change $\Delta \mathrm{H}$ per $1 \mathrm{~b}-$ mole input, in units of B.t.u., may be expressed as

$$
\begin{aligned}
\Delta \mathrm{H}= & \mathrm{CH}_{4} \cdot \Delta \mathrm{H}_{\mathrm{f}, \mathrm{CH}_{4}}+\mathrm{H}_{2} \mathrm{O} \cdot \Delta \mathrm{H}_{\mathrm{f}, \mathrm{H}_{2} \mathrm{O}}+[\mathrm{CO}-(1-\mathrm{a})] \\
& \cdot \Delta \mathrm{H}_{\mathrm{f}, \mathrm{CO}}+\mathrm{CO}_{2} \cdot \Delta \mathrm{H}_{\mathrm{f}, \mathrm{CO}_{2}},
\end{aligned}
$$

where $\Delta \mathrm{H}_{\mathrm{f}, 1}$, in units of $\mathrm{B} . \mathrm{t} . \mathrm{u} / 1 \mathrm{~b}-\mathrm{mole}$, is the heat of formation of the substance $\underline{i}$ which has been calculated using a temperature $\left({ }^{\circ} F\right)$ dependent third-order least-square-fitted equation ${ }^{5}$ as

$$
\Delta \mathrm{H}_{f, 1}=\mathrm{a}_{0, i}+\mathrm{a}_{1, i} \mathrm{t}+\mathrm{a}_{2, i} \mathrm{t}^{2}+\mathrm{a}_{3, i} \mathrm{t}^{3}
$$


The parameters $\underline{a}_{0}, \underline{a}_{1}, \underline{a}_{2}$, and $\underline{a}_{3}$ for Eq. (72) are tabulated in Table II.

\section{Steam-Methane Reforming}

Let $\underline{a}$ and 1 - a be the initial mole fractions of $\mathrm{H}_{2} \mathrm{O}$ and $\mathrm{CH}_{4}$ input to the reformer, and let the final yields of $\mathrm{CH}_{4}, \mathrm{H}_{2} \mathrm{O}, \mathrm{CO}$, and $\mathrm{CO}_{2}$ be $\mathrm{CH}_{4}$, $\mathrm{H}_{2} \mathrm{O}, \mathrm{CO}$, and $\mathrm{CO}_{2}$ moles per mole input, respectively. Then, the enthalpy change $\Delta H$ per lb-mole input, in units of B.t.u., may be expressed as

$$
\begin{aligned}
\Delta \mathrm{H}= & {\left[\mathrm{CH}_{4}-(1-\mathrm{a})\right] \cdot \Delta \mathrm{H}_{\mathrm{f}, \mathrm{CH}_{4}}+\left(\mathrm{H}_{2} \mathrm{O}-\mathrm{a}\right) \cdot \Delta \mathrm{H}_{\mathrm{f}, \mathrm{H}_{2} \mathrm{O}} } \\
& +\mathrm{CO} \cdot \Delta \mathrm{H}_{\mathrm{f}, \mathrm{CO}}+\mathrm{CO}_{2} \cdot \Delta \mathrm{H}_{\mathrm{f}, \mathrm{CO}_{2}}
\end{aligned}
$$

\section{Shift Converter}

Let $\mathrm{IH}_{2} \mathrm{O}$, ICO, and $\mathrm{ICO}_{2}$ be the initial numbers of moles of $\mathrm{H}_{2} \mathrm{O}, \mathrm{CO}$, and $\mathrm{CO}_{2}$ input to the shift converter, and the final yields of $\mathrm{H}_{2} \mathrm{O}, \mathrm{CO}$, and $\mathrm{CO}_{2}$ be $\mathrm{H}_{2} \mathrm{O}, \mathrm{CO}$, and $\mathrm{CO}_{2}$, respectively. Then, the enthalpy change $\Delta \mathrm{H}$ per 1b-mole input, in units of B.t.u., may be expressed as

$$
\begin{aligned}
\Delta \mathrm{H}= & \left(\mathrm{H}_{2} \mathrm{O}-\mathrm{IH}_{2} \mathrm{O}\right) \cdot \Delta \mathrm{H}_{\mathrm{f}, \mathrm{H}_{2} \mathrm{O}}+\left(\mathrm{CO}-\mathrm{ICO} \cdot \Delta \mathrm{H}_{\mathrm{f}, \mathrm{CO}}\right. \\
& +\left(\mathrm{CO}_{2}-\mathrm{ICO}_{2}\right) \cdot \Delta \mathrm{H}_{\mathrm{f}, \mathrm{CO}_{2}} .
\end{aligned}
$$

\section{RESULTS AND DISCUSSION}

\section{A. Methane Synthesis}

In studying methane synthesis, calculations were carried out at temperatures of $600^{\circ} \mathrm{K}, 700^{\circ} \mathrm{K}, 800^{\circ} \mathrm{K}$, and $900^{\circ} \mathrm{K}$, at pressures of 1,10 , 
TABLE II

PARAMETERS OF EQUATION (72) FOR THE HEATS OF FORMATION

\begin{tabular}{ccccc}
\hline Substances & $\mathrm{a}_{\mathrm{O}}$ & $\mathrm{a}_{1}$ & $\mathrm{a}_{2}$ & $\mathrm{a}_{3}$ \\
$\mathrm{CH}_{4}$ & $-3.14291 \times 10^{4}$ & -8.96644 & $3.16520 \times 10^{-3}$ & $-3.67713 \times 10^{-7}$ \\
$\mathrm{H}_{2} \mathrm{O}$ & $-1.03814 \times 10^{5}$ & -2.61524 & $3.25639 \times 10^{-4}$ & $3.68627 \times 10^{-8}$ \\
$\mathrm{CO}$ & $-4.73377 \times 10^{4}$ & $5.13685 \times 10^{-1}$ & $-1.11742 \times 10^{-3}$ & $2.00704 \times 10^{-7}$ \\
$\mathrm{CO}_{2}$ & $-1.69105 \times 10^{5}$ & $5.0 \times 10^{-1}$ & $-1.03398 \times 10^{-25}$ & $2.52435 \times 10^{-29}$ \\
\hline
\end{tabular}


25, and 100 atmospheres. Hydrogen/carbon monoxide ratios of 0.5 to 4.5 were used at all temperatures and pressures except at one atmosphere, where the calculations were extended to a ratio of 5.5 .

For a given set of initial conditions, the sensible heats involved in raising the temperature of the reactants to the temperature of operation were first calculated. At this latter temperature the equilibrium yields of $\mathrm{CH}_{4}, \mathrm{H}_{2} \mathrm{O}, \mathrm{CO}, \mathrm{H}_{2}, \mathrm{CO}_{2}$, and $\mathrm{C}(\mathrm{s})$ were computed, as well as the enthalpy change in the reactor. Finally, the sensible heats involved in cooling the equilibrium mixture of gases back to room temperature were calculated. In carrying out the calculations, the possible precipitation of carbon either as B-graphite or as "Dent" carbon were considered.

Figures 1 to 4 show plots of the mole fraction of ingoing carbon deposited vs. the initial $\mathrm{H}_{2} / \mathrm{CO}$ ratio as a function of pressure and temperature. In all cases, when "Dent" carbon is precipitated, both the mole fraction of ingoing carbon deposited and the minimum $\mathrm{H}_{2} / \mathrm{CO}$ ratio above which carbon no longer precipitates are lower. Plots of the minimum ratio of $\mathrm{H}_{2} / \mathrm{CO}$ above which carbon is no longer deposited are shown as a function of temperature and pressure in Figure 5. When B-graphite is the form of carbon deposited, the effects of pressure and temperature on the minimum ratio are slight except at one atmosphere pressure, where the ratio increases markedly at higher temperatures. When "Dent" carbon is deposited the minimum ratios all increase as the temperature increases, with the greatest effect again at one atmosphere pressure. In a11 cases, at constant temperature, as the pressure increases the minimum ratio decreases. 


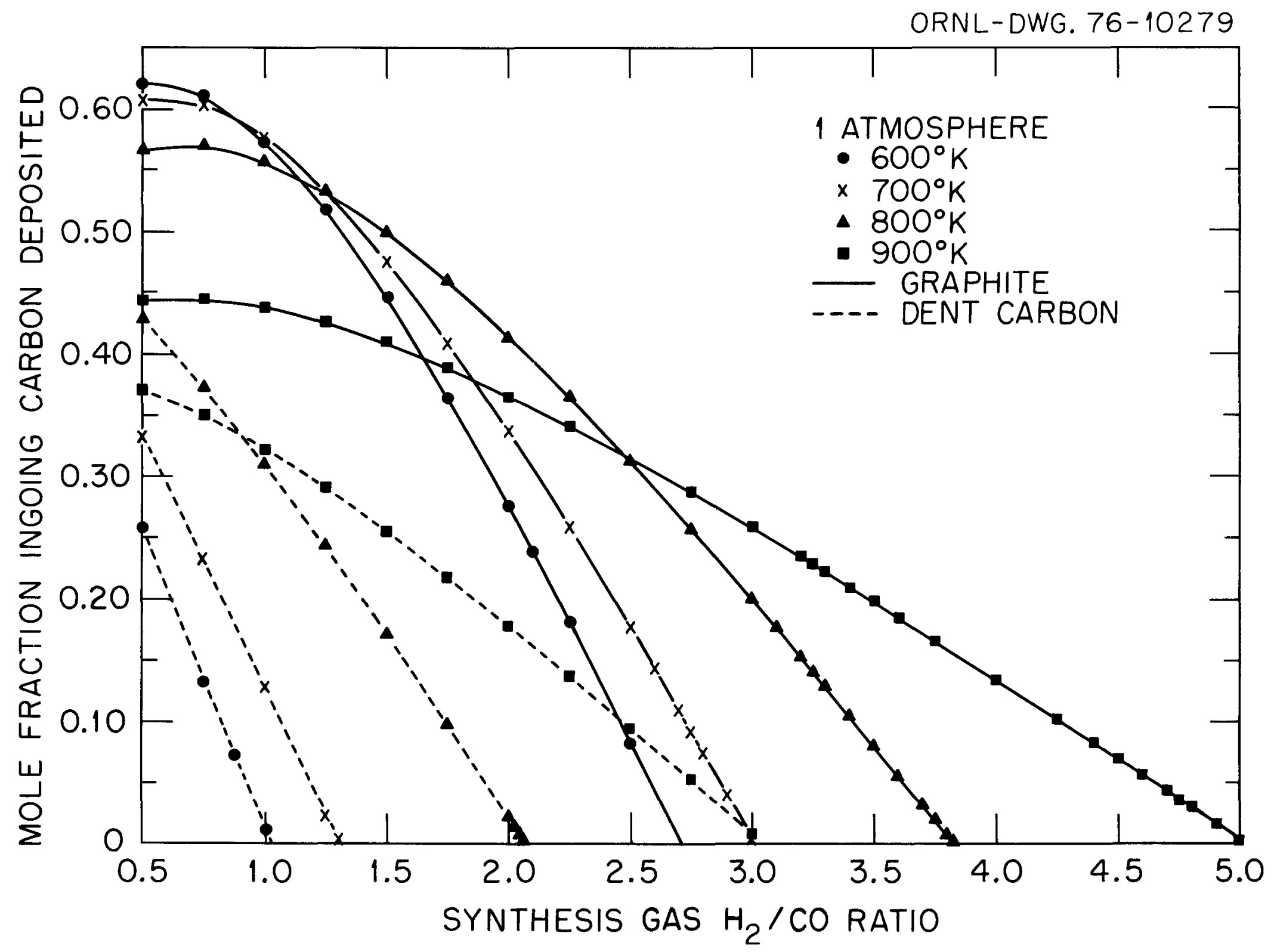

Fig. 1. Plots of Mole Fraction of Ingoing Carbon Deposited vs. Initial $\mathrm{H}_{2} /$ Co Ratio for Methane Synthesis at a Total Pressure of One Atmosphere. 


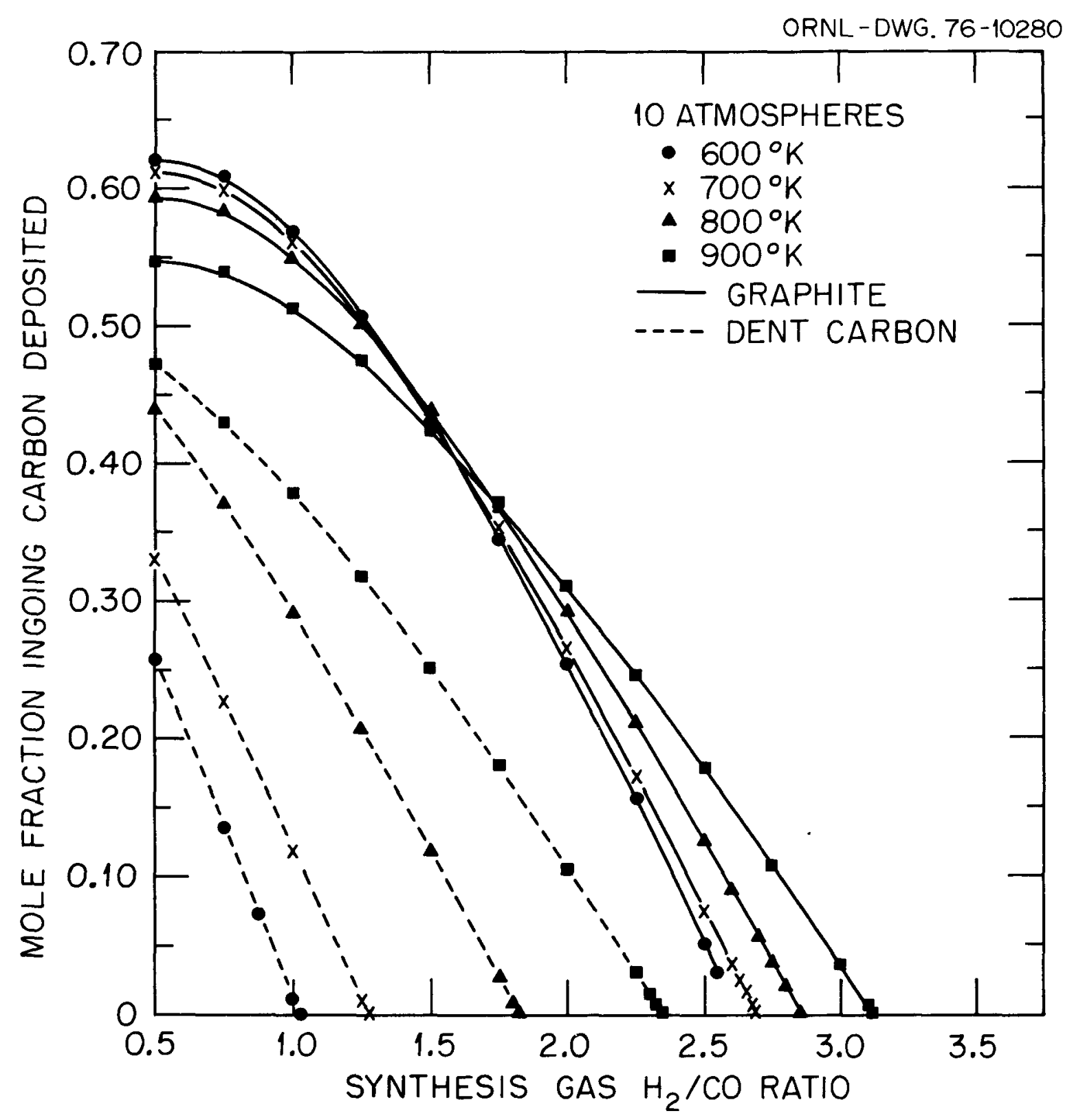

Fig. 2. Plots of Mole Fraction of Ingoing Carbon Deposited vs. Initial $\mathrm{H}_{2} /$ Co Ratio for Methane Synthesis at a Total Pressure of 10 Atmospheres. 


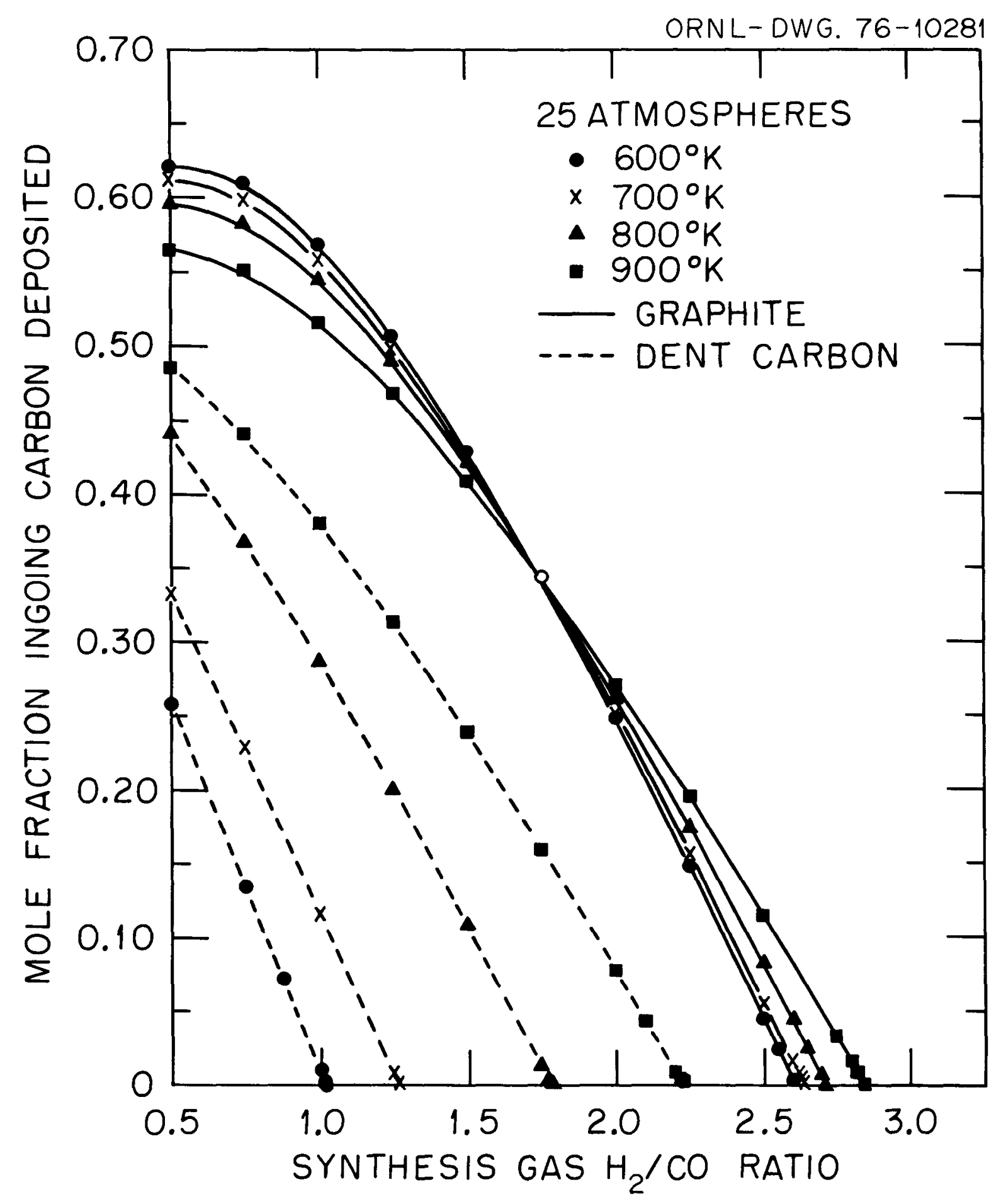

Fig. 3. Plots of Mole Fraction of Ingoing Carbon Deposited vs. Initial $\mathrm{H}_{2} / \mathrm{CO}$ Ratio for Methane Synthesis at a Total Pressure of 25 atmospheres. 


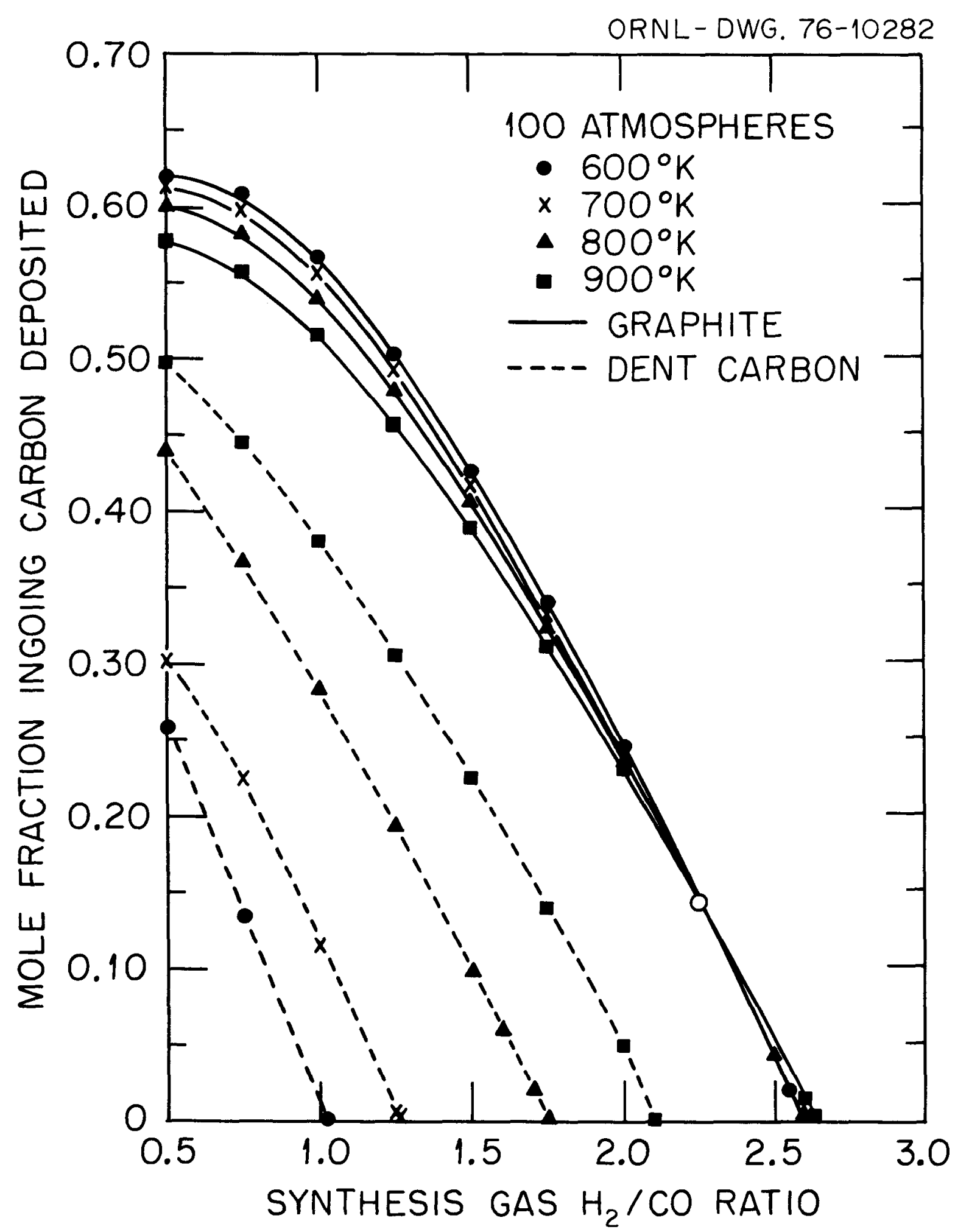
Fig. 4. Plots of Mole Fraction of Ingoing Carbon Deposited vs. Initial $\mathrm{H}_{2} / \mathrm{CO}$ Ratio
for Methane Synthesis at a Total Pressure of 100 Atmospheres. 


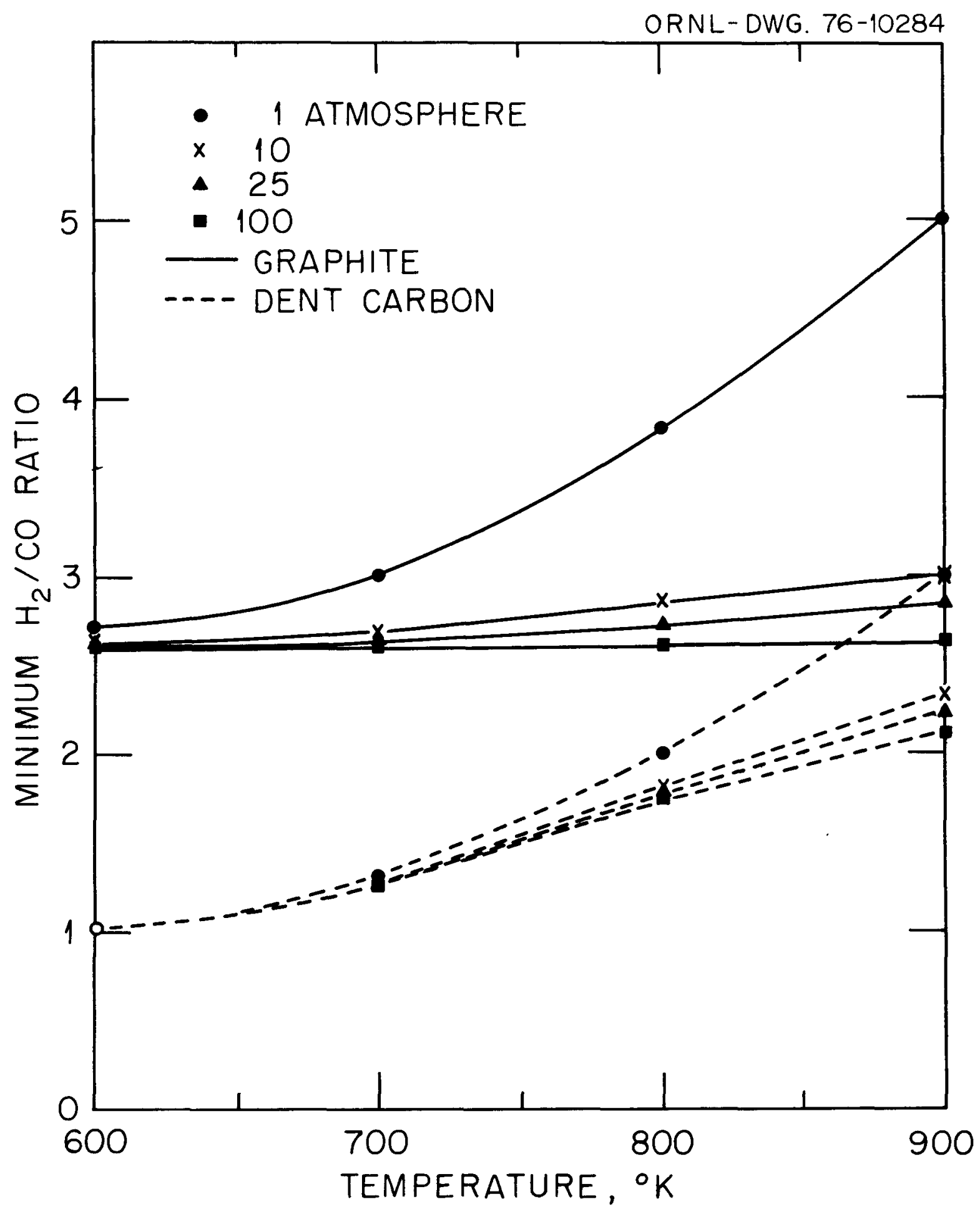

Fig. 5. Temperature Dependence of the Minimum $\mathrm{H}_{2} / \mathrm{CO}$ Ratio Above Which Carbon No Longer Precipitates $\left({ }^{\circ} \mathrm{K}\right)$. 
Plots of the theoretical equilibrium yields of methane in moles per mole input gas vs. the initial $\mathrm{H}_{2} / \mathrm{CO}$ ratio are shown as a function of pressure and temperature in Figures 6 through 9 . As the initial $\mathrm{H}_{2} / \mathrm{CO}$ ratio increases, the methane yield increases and the amount of carbon precipitated decreases. At the point where carbon no longer precipitates, either as "Dent" carbon or B-graphite, the methane yield reaches its maximum. As the $\mathrm{H}_{2} / \mathrm{CO}$ ratio is increased beyond this point, the methane yield falls off.

In Table III are listed values of the equilibrium amounts of $\mathrm{CH}_{4}$, $\mathrm{H}_{2} \mathrm{O}, \mathrm{CO}, \mathrm{H}_{2}$, and $\mathrm{CO}_{2}$ (moles per mole input $\left(\mathrm{H}_{2}+\mathrm{CO}\right.$ ) at the minimum $\mathrm{H}_{2} / \mathrm{CO}$ ratio where $\beta$-graphite no longer precipitates, while corresponding values for the minimum ratio where "Dent" carbon no longer precipitates are shown in Table IV. Under these conditions the yield of methane is a maximum. At $600^{\circ} \mathrm{K}$ the effect of pressure on the amount of methane produced is very slight, and essentially the same amount of $\mathrm{CH}_{4}$ is produced whether $B-$ graphite or "Dent" carbon is precipitated. The minimum $\mathrm{H}_{2} / \mathrm{CO}$ ratios are al1 lower for "Dent" carbon but becomes closer to those for $\beta$-graphite as the temperature increases. At one atmosphere pressure the yield of methane decreases markedly as the temperature increases, but as the pressure is increased the yields at the higher temperatures approach those obtained at $600^{\circ} \mathrm{K}$. The equilibrium amounts of $\mathrm{H}_{2} \mathrm{O}, \mathrm{CO}, \mathrm{H}_{2}$, and $\mathrm{CO}_{2}$ are also shown in Tables III and IV.

The minimum ratios obtained in this work are lower than those obtained by M. Greyson and co-workers ${ }^{2}$ at $600^{\circ} \mathrm{K}$, but higher at 700,800 , and $900^{\circ} \mathrm{K}$. Moreover, the methane yields obtained in this work are higher than those obtained by M. Greyson and co-workers at $600^{\circ} \mathrm{K}$, but lower at 


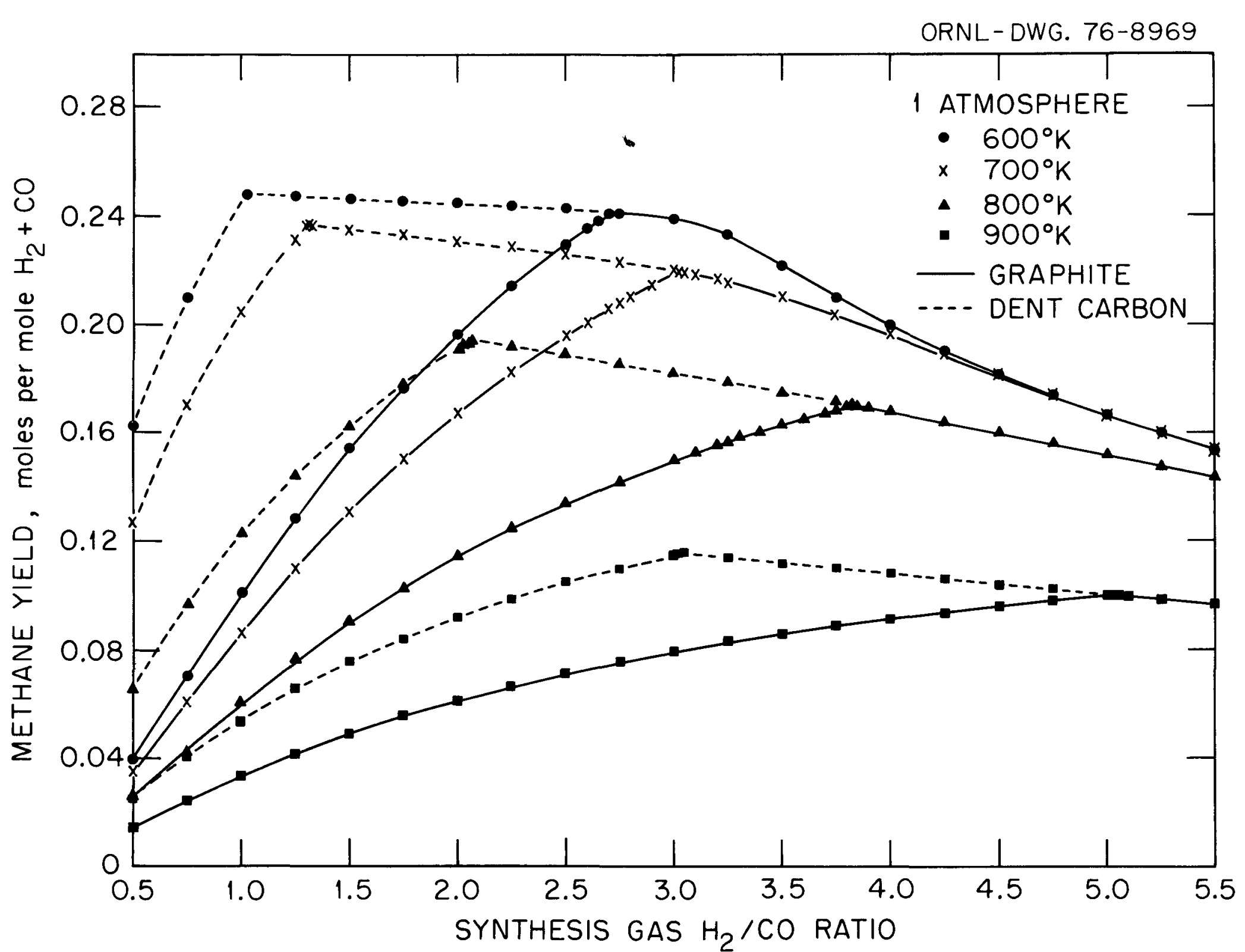

Fig. 6. Methane Yield vs. Initial $\mathrm{H}_{2} / \mathrm{CO}$ Ratio at One Atmospheres Total Pressure. 


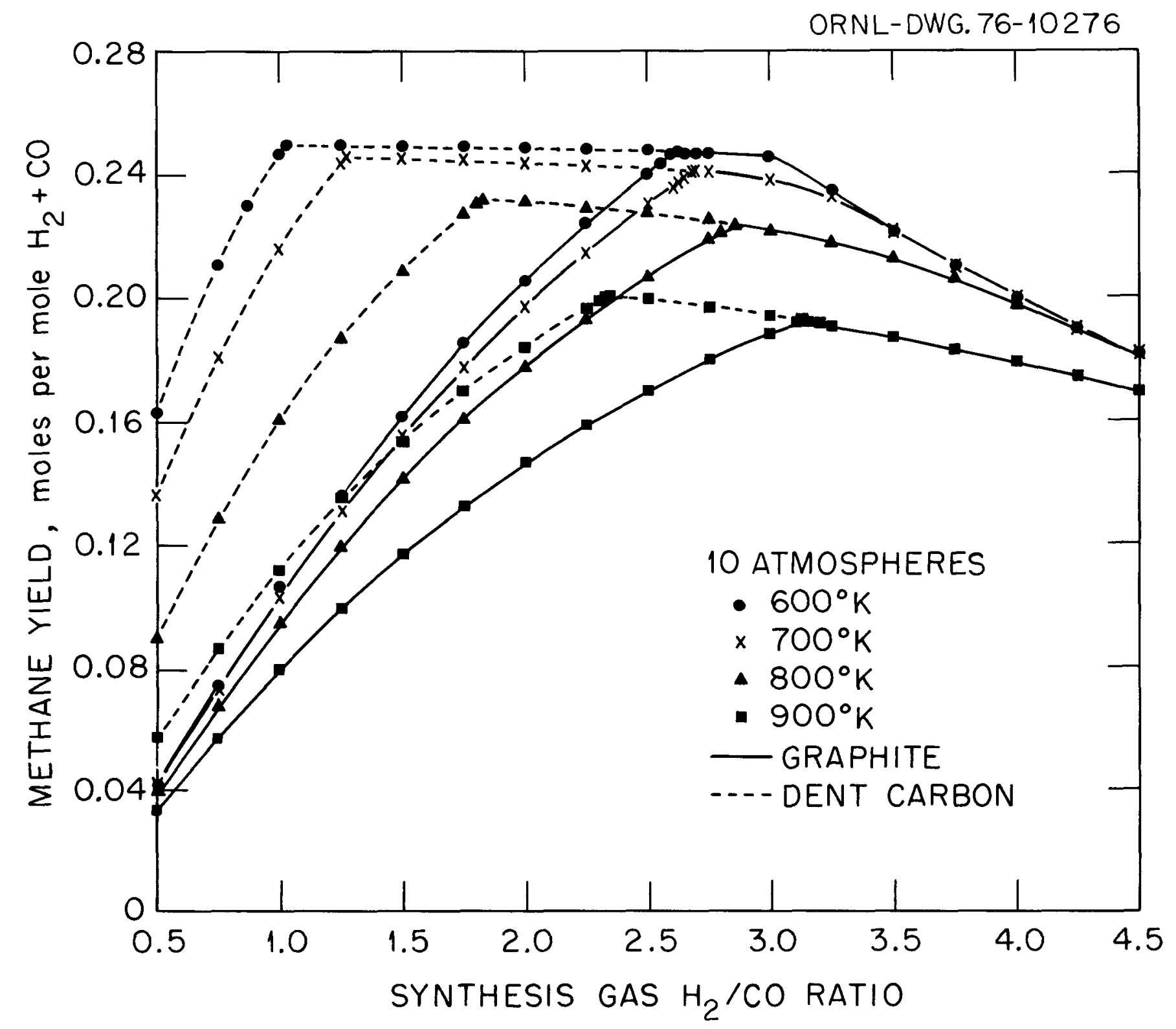

Fig. 7. Methane Yield vs. Initial $\mathrm{H}_{2} / \mathrm{CO}$ Ratio at 10 Atmospheres Total Pressure. 


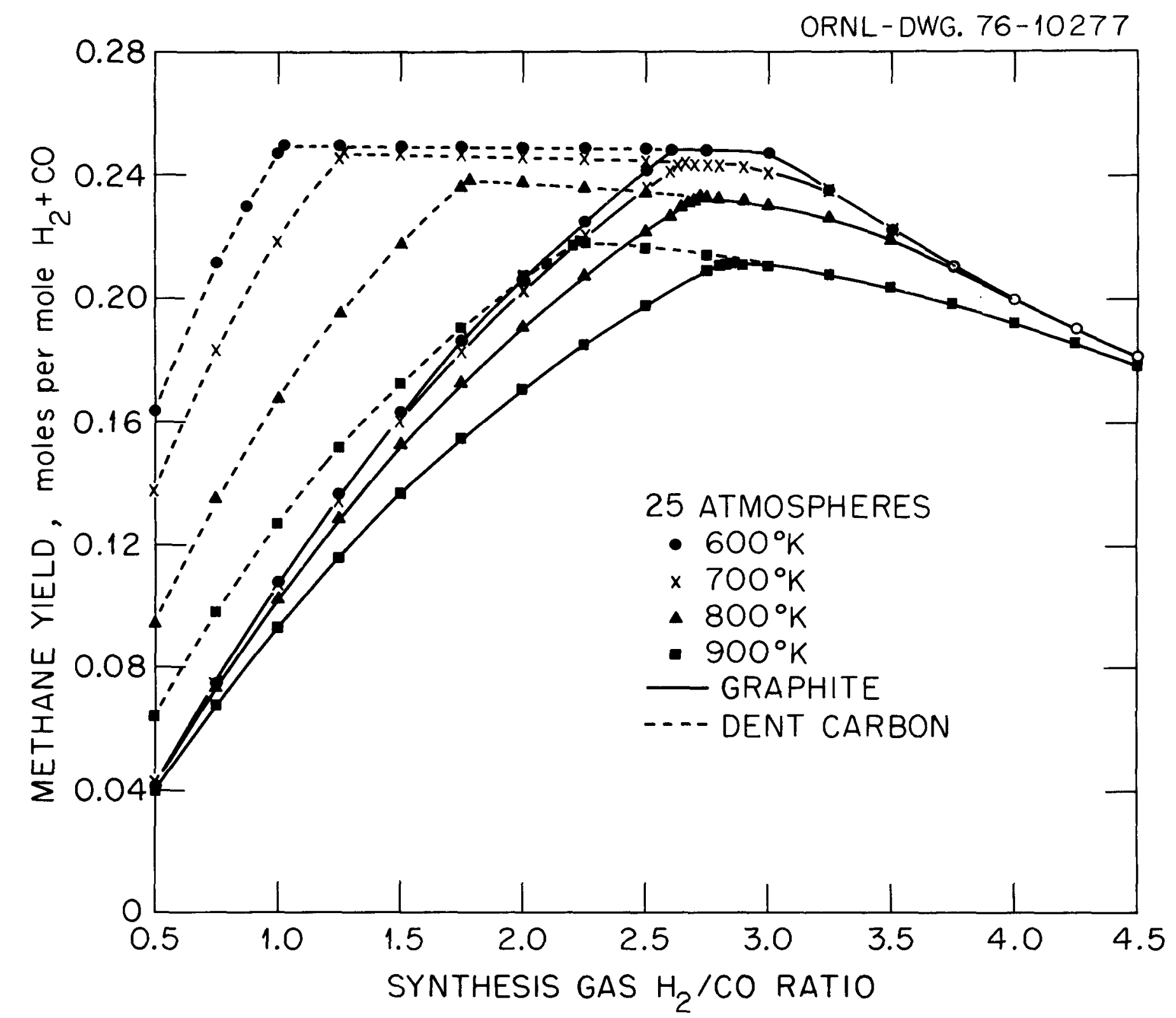

Fig. 8. Methane Yield vs. Initial $\mathrm{H}_{2} / \mathrm{CO}$ Ratio at 25 Atmospheres Total Pressure. 


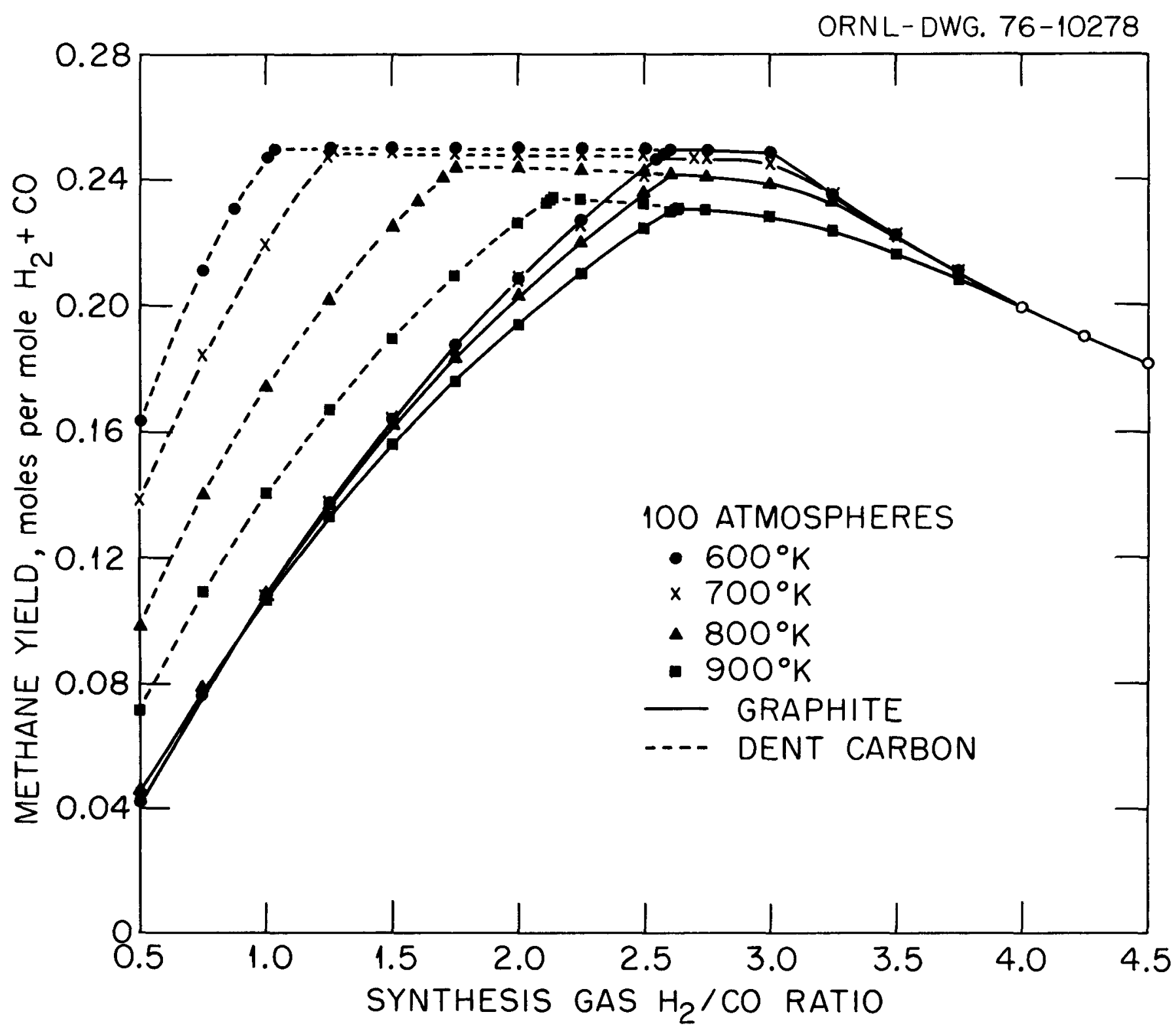

Fig. 9. Methane Yield vs. Initial $\mathrm{H}_{2} / \mathrm{CO}$ Ratio at 100 Atmospheres Total Pressure. 


\section{TABLE III}

THEORETICAL EQUILIBRIUM YIELDS, MOLES PER MOLE INPUT $\left(\mathrm{H}_{2}+\mathrm{CO}\right)$, FOR METHANE SYNTHESIS. VALUES ARE AT THE MINIMUM RATIO WHERE B-GRAPHITE NO LONGER PRECIPITATES

\begin{tabular}{cccccccc}
\hline P (atm) & $\mathrm{T}^{\circ} \mathrm{K}$ & $\begin{array}{c}\text { minimum } \\
\text { ratio }\end{array}$ & $\mathrm{CH}_{4}$ & $\mathrm{H}_{2} \mathrm{O}$ & $\mathrm{CO}$ & $\mathrm{H}_{2}$ & $\mathrm{CO}_{2}$ \\
\hline \multirow{2}{*}{1} & 600 & 2.710 & 0.241495 & 0.213612 & 0.000164 & 0.033855 & 0.027883 \\
& 700 & 3.015 & .219636 & .192060 & .001855 & .119603 & .027576 \\
& 800 & 3.830 & .170465 & .146334 & .012443 & .305697 & .024131 \\
& 900 & 5.025 & .100470 & .084153 & .049188 & .548932 & .016317 \\
10 & 600 & 2.625 & .247308 & .218805 & .000052 & .010718 & .028503 \\
& 700 & 2.690 & .240325 & .210237 & .000589 & .038110 & .030088 \\
& 800 & 2.855 & .223619 & .191962 & .004128 & .101397 & .031657 \\
& 900 & 3.120 & .192570 & .161306 & .018884 & .210836 & .031264 \\
& & & & & & \\
& & & & & & & \\
& 600 & 2.610 & .248298 & .219621 & .000033 & .006774 & .028677 \\
& 700 & 2.640 & .243875 & .213397 & .000372 & .024128 & .030478 \\
& 800 & 2.720 & .233249 & .200296 & .002615 & .064388 & .032953 \\
& 900 & 2.850 & .213076 & .178533 & .012122 & .135575 & .034542 \\
& & & & & & \\
& 600 & 2.600 & .249148 & .220534 & .000016 & .003393 & .028614 \\
& 700 & 2.595 & .246942 & .215907 & .000187 & .012045 & .031035 \\
& 800 & 2.610 & .241608 & .207515 & .001308 & .032261 & .034092 \\
& 900 & 2.635 & .231394 & .193807 & .006122 & .068302 & .037587 \\
\hline
\end{tabular}


TABLE IV

THEORETICAL EQUILIBRIUM YIELDS, MOLES PER MOLE INPUT $\left(\mathrm{H}_{2}+\mathrm{CO}\right)$, FOR METHANE SYNTHESIS. VALUES ARE AT THE MINIMUM RATIO WHERE "DENT" CARBON NO LONGER PRECIPITATES

\begin{tabular}{|c|c|c|c|c|c|c|c|}
\hline$P($ atm) & $\mathrm{T}^{\circ} \mathrm{K}$ & $\begin{array}{l}\text { minimum } \\
\text { ratio }\end{array}$ & $\mathrm{CH}_{4}$ & $\mathrm{H}_{2} \mathrm{O}$ & $\mathrm{CO}$ & $\mathrm{H}_{2}$ & $\mathrm{CO}_{2}$ \\
\hline 1 & $\begin{array}{l}600 \\
700 \\
800 \\
900\end{array}$ & $\begin{array}{l}1.025 \\
1.310 \\
2.065 \\
3.045\end{array}$ & $\begin{array}{r}0.247972 \\
.236645 \\
.194320 \\
.115885\end{array}$ & $\begin{array}{r}0.006742 \\
.054547 \\
.102623 \\
.079185\end{array}$ & $\begin{array}{r}0.004625 \\
.014156 \\
.040247 \\
.094633\end{array}$ & $\begin{array}{r}0.003486 \\
.039262 \\
.182473 \\
.441826\end{array}$ & $\begin{array}{r}0.241230 \\
.182099 \\
.091697 \\
.036700\end{array}$ \\
\hline 10 & $\begin{array}{l}600 \\
700 \\
800 \\
900\end{array}$ & $\begin{array}{l}1.025 \\
1.275 \\
1.825 \\
2.345\end{array}$ & $\begin{array}{r}.249356 \\
.245774 \\
.231962 \\
.200721\end{array}$ & $\begin{array}{r}.006392 \\
.056481 \\
.122906 \\
.137217\end{array}$ & $\begin{array}{l}.001508 \\
.004492 \\
.012964 \\
.034730\end{array}$ & $\begin{array}{r}.001070 \\
.012410 \\
.059187 \\
.162388\end{array}$ & $\begin{array}{l}.242964 \\
.189294 \\
.109056 \\
.063503\end{array}$ \\
\hline 25 & $\begin{array}{l}600 \\
700 \\
800 \\
900\end{array}$ & $\begin{array}{l}1.025 \\
1.270 \\
1.785 \\
2.230\end{array}$ & $\begin{array}{r}.249952 \\
.247326 \\
.238578 \\
.218449\end{array}$ & $\begin{array}{r}.006317 \\
.056960 \\
.126310 \\
.149480\end{array}$ & $\begin{array}{l}.000960 \\
.002837 \\
.008221 \\
.022180\end{array}$ & $\begin{array}{l}.000672 \\
.007859 \\
.037468 \\
.104025\end{array}$ & $\begin{array}{r}.243275 \\
.190366 \\
.112268 \\
.068969\end{array}$ \\
\hline 100 & $\begin{array}{l}600 \\
700 \\
800 \\
900\end{array}$ & $\begin{array}{l}1.025 \\
1.265 \\
1.750 \\
2.135\end{array}$ & $\begin{array}{l}.249796 \\
.248663 \\
.244289 \\
.234120\end{array}$ & $\begin{array}{r}.006247 \\
.057244 \\
.129067 \\
.160391\end{array}$ & $\begin{array}{l}.000483 \\
.001419 \\
.004125 \\
.011129\end{array}$ & $\begin{array}{r}.000334 \\
.003929 \\
.018719 \\
.052389\end{array}$ & $\begin{array}{r}.243548 \\
.191419 \\
.115222 \\
.073730\end{array}$ \\
\hline
\end{tabular}


700,800 , and $900^{\circ} \mathrm{K}$. The differences between these two studies are larger at higher temperatures and lower pressures.

Table $\mathrm{V}$ shows the total heat balance in the synthesis of methane with $\beta$-graphite the form of carbon precipitated, while Table VI shows the same quantities when "Dent" carbon precipitates. All values were computed at the minimum $\mathrm{H}_{2} / \mathrm{CO}$ ratio where carbon no longer precipitates and where the yield of methane is a maximum. The net amount of heat evolved correlates strongly with the minimum ratio value: the higher the minimum ratio the less heat evolved. The effect of temperature is the greatest at one atmosphere pressure, becoming almost negligible at 100 atmospheres. Under the same conditions of temperature and pressure, more heat is evolved when "Dent" carbon is the form precipitated. The effect is most pronounced at $600^{\circ} \mathrm{K}$ and becomes increasingly less as the temperature increases.

\section{B. Steam-Methane Reforming}

Calculations for the steam-methane reforming process have been carried out at various temperatures $\left(1200^{\circ} \mathrm{F}, 1400^{\circ} \mathrm{F}, 1600^{\circ} \mathrm{F}, 1800^{\circ} \mathrm{F}\right.$, and $2000^{\circ} \mathrm{F}$ ), pressures (5 atm, $10 \mathrm{~atm}, 20 \mathrm{~atm}, 30 \mathrm{~atm}$, and $40 \mathrm{~atm}$ ), and initial steam- methane ratios (from 0.7 to 3.0 ).

For a given set of initial conditions, the sensible heats involved in raising the temperature of steam and methane from room temperature to the temperature at the bottom end of the reformer and from the latter temperature to the temperature at the top end were calculated. The temperature differential in the reformer has been taken in all cases as $600^{\circ} \mathrm{F}$. Then the equilibrium yields of $\mathrm{CH}_{4}, \mathrm{H}_{2} \mathrm{O}, \mathrm{CO}, \mathrm{H}_{2}, \mathrm{CO}_{2}$, and $\mathrm{C}(\mathrm{s})$ 
TABLE $\mathrm{V}$

TOTAL HEAT BALANCES IN THE SYNTHESIS OF METHANE WITH GRAPHITE THE FORM OF CARBON PRECIPITATED

\begin{tabular}{|c|c|c|c|c|c|c|}
\hline $\begin{array}{c}\mathrm{p} \\
(\mathrm{atm})\end{array}$ & $\begin{array}{c}\mathrm{T} \\
\left({ }^{\circ} \mathrm{K}\right)\end{array}$ & $\begin{array}{l}\text { Minimum } \\
\text { Ratio }\end{array}$ & $\begin{array}{c}\mathrm{SH}_{293 \cdot 15^{\circ} \mathrm{K} \rightarrow \mathrm{T}} \\
\mathrm{x} 10^{-3} \\
\text { B.t.u. } / 1 \mathrm{~b}-\mathrm{mole} \\
\text { input } \\
\end{array}$ & $\begin{array}{c}\Delta \mathrm{H}_{\text {reactor }} \\
\times 10^{-3} \\
\text { B.t.u./1b-mole } \\
\text { input } \\
\end{array}$ & $\begin{array}{c}\mathrm{SH}_{\mathrm{T} \rightarrow 293 \cdot 15^{\circ} \mathrm{K}} \\
\times 10^{-3} \\
\text { B.t.u. } / 1 \mathrm{~b}-\mathrm{mole} \\
\text { input }\end{array}$ & $\begin{array}{c}\Delta \mathrm{H}_{\text {total }} \\
\times 10^{-3} \\
\text { B.t.u. } / 1 \mathrm{~b}-\text { mole } \\
\text { input } \\
\end{array}$ \\
\hline 1 & 600 & 2.710 & 3.843 & -23.109 & -2.721 & -21.987 \\
\hline 1 & 700 & 3.015 & 5.121 & -21.294 & -3.859 & -20.032 \\
\hline 1 & 800 & 3.830 & 6.407 & -16.719 & -5.274 & -15.586 \\
\hline 1 & 900 & 5.025 & 7.700 & -9.953 & -6.963 & -9.216 \\
\hline 10 & 600 & 2.625 & 3.844 & -23.664 & -2.695 & -22.515 \\
\hline 10 & 700 & 2.690 & 5.125 & -23.298 & -3.744 & -21.917 \\
\hline 10 & 800 & 2.855 & 6.420 & -21.932 & -4.934 & -20.446 \\
\hline 10 & 900 & 3.120 & 7.726 & -19.077 & -6.314 & -17.665 \\
\hline 25 & 600 & 2.610 & 3.844 & -23.760 & -2.690 & -22.606 \\
\hline 25 & 700 & 2.640 & 5.126 & -23.642 & -3.724 & -22.240 \\
\hline 25 & 800 & 2.720 & 6.422 & -22.876 & -4.872 & -21.326 \\
\hline 25 & 900 & 2.850 & 7.732 & -21.108 & -6.169 & -19.545 \\
\hline 100 & 600 & 2.600 & 3.844 & -23.839 & -2.686 & -22.681 \\
\hline 100 & 700 & 2.595 & 5.126 & -23.942 & -3.707 & -22.523 \\
\hline 100 & 800 & 2.610 & 6.424 & -23.695 & -4.819 & -22.090 \\
\hline 100 & 900 & 2.635 & 7.737 & -22.924 & -6.040 & -21.227 \\
\hline
\end{tabular}




\section{TABLE VI}

TOTAL HEAT BALANCES IN THE SYNTHESIS OF METHANE WITH "DENT" CARBON THE FORM OF CARBON PRECIPITATED

\begin{tabular}{|c|c|c|c|c|c|c|}
\hline$\underset{(a t m)}{p}$ & $\begin{array}{c}\mathrm{T} \\
\left({ }^{\circ} \mathrm{K}\right)\end{array}$ & $\begin{array}{l}\text { Minimum } \\
\text { Ratio }\end{array}$ & $\begin{array}{c}\mathrm{SH}_{293 \cdot 15^{\circ} \mathrm{K} \rightarrow \mathrm{T}} \\
\times 10^{-3} \\
\text { B.t.u. } / 1 \mathrm{~b}-\mathrm{mole} \\
\text { input } \\
\end{array}$ & $\begin{array}{c}\Delta \mathrm{H}_{\text {reactor }} \\
\times 10^{-3} \\
\text { B.t.u./1b-mole } \\
\text { input } \\
\end{array}$ & $\begin{array}{c}\mathrm{SH}_{\mathrm{T} \rightarrow 293 \cdot 15^{\circ} \mathrm{K}} \\
\mathrm{x} 10^{-3} \\
\text { B.t.u. } / 1 \mathrm{~b}-\mathrm{mole} \\
\text { input } \\
\end{array}$ & $\begin{array}{c}\Delta \mathrm{H}_{\text {total }} \\
\times 10^{-3} \\
\text { B.t.u. } / 1 \mathrm{~b}-\mathrm{mole} \\
\text { input } \\
\end{array}$ \\
\hline $\begin{array}{l}1 \\
1 \\
1 \\
1\end{array}$ & $\begin{array}{l}600 \\
700 \\
800 \\
900\end{array}$ & $\begin{array}{l}1.025 \\
1.310 \\
2.065 \\
3.045\end{array}$ & $\begin{array}{l}3.867 \\
5.153 \\
6.436 \\
7.727\end{array}$ & $\begin{array}{l}-27.282 \\
-25.425 \\
-20.076 \\
-11.756\end{array}$ & $\begin{array}{l}-2.965 \\
-4.036 \\
-5.275 \\
-6.921\end{array}$ & $\begin{array}{l}-26.380 \\
-24.308 \\
-18.915 \\
-10.950\end{array}$ \\
\hline $\begin{array}{l}10 \\
10 \\
10 \\
10\end{array}$ & $\begin{array}{l}600 \\
700 \\
800 \\
900\end{array}$ & $\begin{array}{l}1.025 \\
1.275 \\
1.825 \\
2.345\end{array}$ & $\begin{array}{l}3.867 \\
5.154 \\
6.443 \\
7.745\end{array}$ & $\begin{array}{l}-27.440 \\
-26.408 \\
-23.958 \\
-20.361\end{array}$ & $\begin{array}{l}-2.960 \\
-3.995 \\
-5.056 \\
-6.348\end{array}$ & $\begin{array}{l}-26.533 \\
-25.249 \\
-22.571 \\
-18.964\end{array}$ \\
\hline $\begin{array}{l}25 \\
25 \\
25 \\
25\end{array}$ & $\begin{array}{l}600 \\
700 \\
800 \\
900\end{array}$ & $\begin{array}{l}1.025 \\
1.270 \\
1.785 \\
2.230\end{array}$ & $\begin{array}{l}3.867 \\
5.154 \\
6.444 \\
7.749\end{array}$ & $\begin{array}{l}-27.468 \\
-26.573 \\
-24.643 \\
-22.157\end{array}$ & $\begin{array}{l}-2.960 \\
-3.987 \\
-5.018 \\
-6.228\end{array}$ & $\begin{array}{l}-26.561 \\
-25.406 \\
-23.217 \\
-20.636\end{array}$ \\
\hline $\begin{array}{l}100 \\
100 \\
100 \\
100\end{array}$ & $\begin{array}{l}600 \\
700 \\
800 \\
900\end{array}$ & $\begin{array}{l}1.025 \\
1.265 \\
1.750 \\
2.135\end{array}$ & $\begin{array}{l}3.867 \\
5.154 \\
6.446 \\
7.752\end{array}$ & $\begin{array}{l}-27.492 \\
-26.717 \\
-25.237 \\
-23.744\end{array}$ & $\begin{array}{l}-2.959 \\
-3.981 \\
-4.985 \\
-6.122\end{array}$ & $\begin{array}{l}-26.584 \\
-25.544 \\
-23.776 \\
-22.114\end{array}$ \\
\hline
\end{tabular}


were computed at the temperature at the top end of the reformer, as well as the enthalpy of reaction. Next the sensible heats involved in cooling the equilibrium gas mixture to the temperature of the shift converter were calculated. The temperature of operation of the shift converter was taken in a11 cases as $750^{\circ} \mathrm{F}$. At this temperature the equilibrium yields of $\mathrm{H}_{2} \mathrm{O}, \mathrm{CO}, \mathrm{H}_{2}, \mathrm{CO}_{2}$, and $\mathrm{C}(\mathrm{s}$ ) were recalculated as well as the enthalpy change in the shift converter. Finally, the sensible heats involved in cooling the equilibrium gas mixture to room temperature were calculated.

Figure 10 shows the effect of temperature and pressure on the minimum $\mathrm{H}_{2} \mathrm{O} / \mathrm{CH}_{4}$ ratio above which carbon no longer precipitates in the reformer. The effect of pressure is greatest at the lowest temperature and at any given temperature the minimum ratio decreases as the pressure increases.

In Figure 11 are shown plots of the hydrogen yield in methane steam reforming as a function of temperature, pressure, and the $\mathrm{H}_{2} \mathrm{O} / \mathrm{CH}_{4}$ ratio R. Except at $1200^{\circ} \mathrm{F}$, pressure has little influence on the hydrogen yield at various ratios of $\mathrm{H}_{2} \mathrm{O} \mathrm{CH}_{4} \cdot$ At $1200^{\circ} \mathrm{F}$ the hydrogen yield steadily decreases as the pressure increases. At any given pressure the amount of hydrogen produced at $1200^{\circ} \mathrm{F}$ for any $\mathrm{H}_{2} \mathrm{O} / \mathrm{CH}_{4}$ ratio from 1.5 to 3.0 is nearly the same. At higher temperatures much more hydrogen is produced at the lower ratio of $\mathrm{H}_{2} \mathrm{O} / \mathrm{CH}_{4}$.

In Figure 12 are shown the equilibrium yields of $\mathrm{H}_{2} \mathrm{O}, \mathrm{CO}_{2}, \mathrm{CO}$, and $\mathrm{CH}_{4}$ in steam-methane reforming as a function of pressure, temperature, and the initial $\mathrm{H}_{2} \mathrm{O} / \mathrm{CH}_{4}$ ratio. The amount of $\mathrm{CO}_{2}$ present at equilibrium is practically unaffected by these variables. At any given $\mathrm{H}_{2} \mathrm{O} / \mathrm{CH}_{4}$ ratio the amount of $\mathrm{H}_{2} \mathrm{O}$ at equilibrium increases at constant temperature as the 


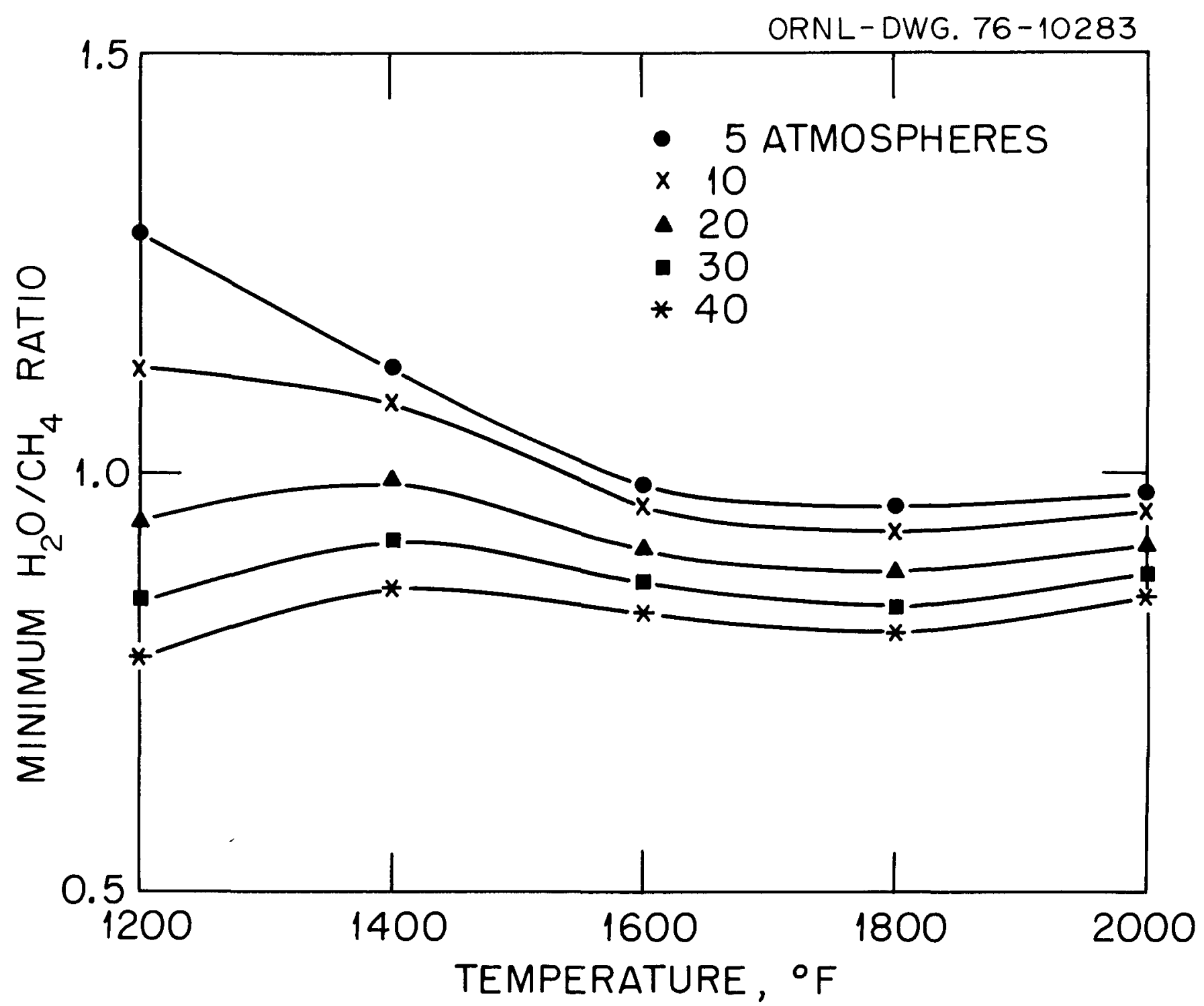
Fig. 10. The Effect of Temperature and Pressure on the Minimum $\mathrm{H}_{2} \mathrm{O} / \mathrm{CH}_{4}$ Ratio Above
Which Carbon No Longer Precipitates in the Reformer. 
ORNL-DWG. $76-10285$

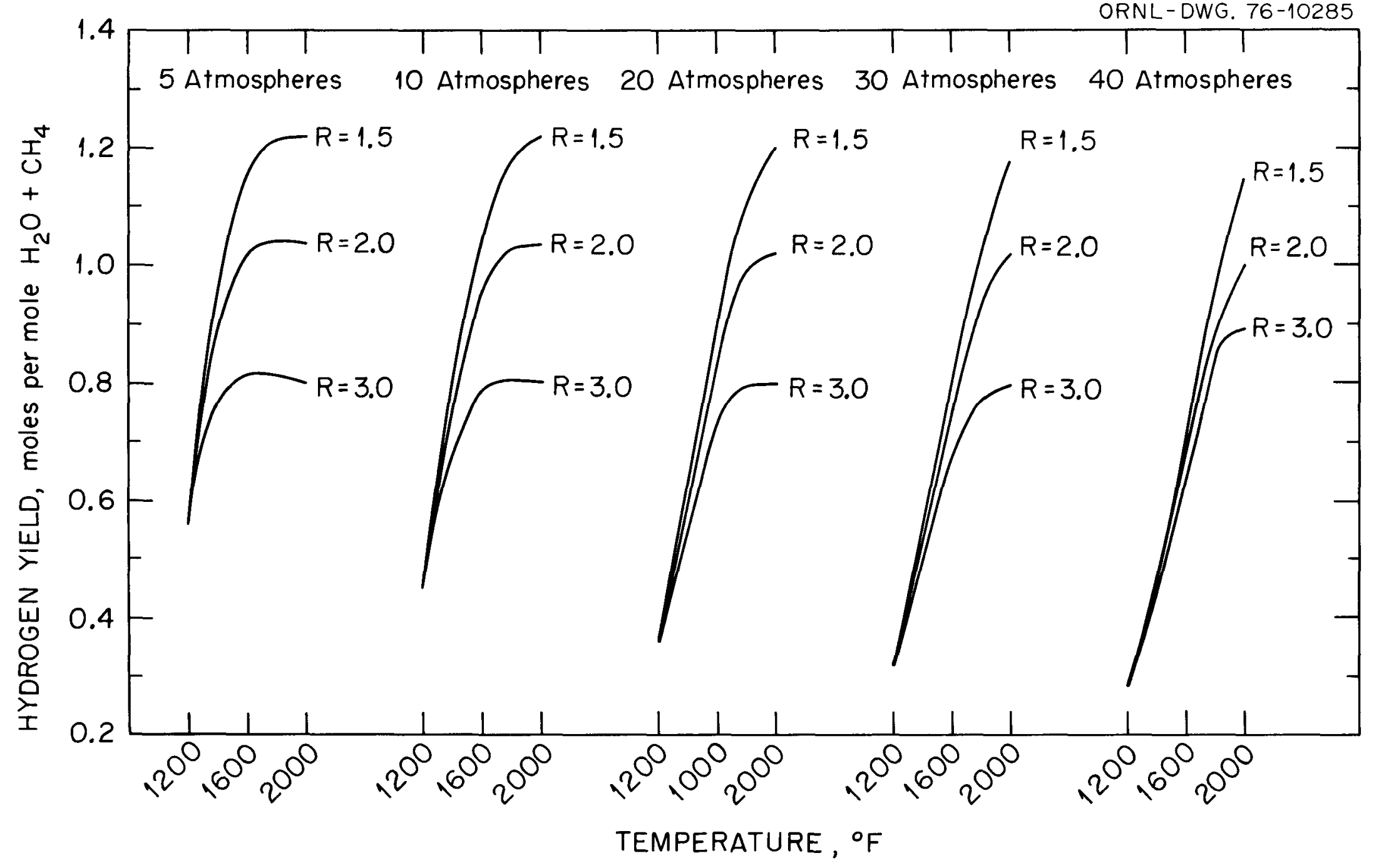

Fig. 11. Hydrogen Yields in Methane-Steam Reforming as a Function of Temperature, Pressure, and Initial $\mathrm{H}_{2} \mathrm{O}_{4} \mathrm{CH}_{4}$ Ratio. 


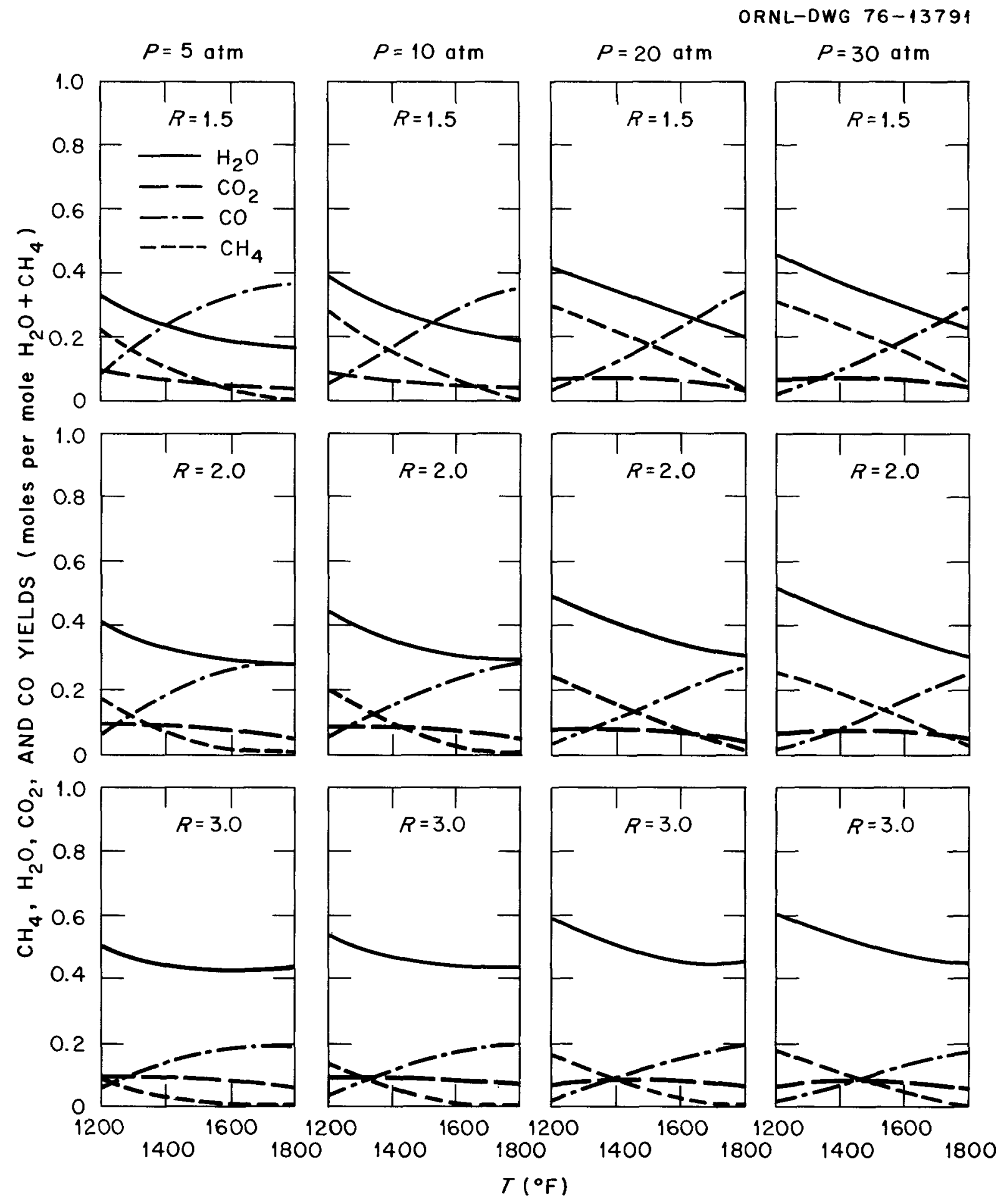

Fig. 12. Equilibrium Yields of $\mathrm{H}_{2} \mathrm{O}, \mathrm{CO}_{2}, \mathrm{CO}$, and $\mathrm{CH}_{4}$ in Steam-Methane Reforming as a Function of Pressure, Temperature, and Initial $\mathrm{H}_{2} \mathrm{O} / \mathrm{CH}_{4}$ Ratio. 
pressure increases, while at constant pressure and temperature the amount of $\mathrm{H}_{2} \mathrm{O}$ increases as the $\mathrm{H}_{2} \mathrm{O}_{\mathrm{CH}}$ ratio increases. At constant initial $\mathrm{H}_{2} \mathrm{O} / \mathrm{CH}_{4}$ ratio the amount of $\mathrm{CO}$ at equilibrium decreases at constant temperature as the pressure increases; this effect becomes less at higher initial $\mathrm{H}_{2} \mathrm{O} / \mathrm{CH}_{4}$ ratios. At constant pressure the amount of $\mathrm{CO}$ at equilibrium is practically independent of temperature at $1200^{\circ} \mathrm{F}$; at the higher temperatures the amount decreases as the initial $\mathrm{H}_{2} \mathrm{O} / \mathrm{CH}_{4}$ ratio increases. Finally, the amount of $\mathrm{CH}_{4}$ remaining at equilibrium increases at constant temperature and initial $\mathrm{H}_{2} \mathrm{O} / \mathrm{CH}_{4}$ ratio as the pressure increases, while if pressure and temperature are held constant the amount of $\mathrm{CH}_{4}$ remaining decreases as the initial $\mathrm{H}_{2} \mathrm{O} / \mathrm{CH}_{4}$ ratio increases.

In Table VII are shown total heat balances for steam-methane reforming at total pressures of 5 and 40 atmospheres, upper reformer temperatures of $1200^{\circ}, 1600^{\circ}$, and $1800^{\circ} \mathrm{F}$, shift converter temperature of $750^{\circ} \mathrm{F}$, and a steam/methane ratio of 1.5 . At constant temperature, increasing the pressure decreases the heat needed, the effect being greater at lower temperatures. 
TABLE VII

TOTAL HEAT BALANCES UNDER SPECIFIED CONDITIONS FOR METHANE-STEAM REFORMING AT AN INITIAL

$\mathrm{H}_{2} \mathrm{O} / \mathrm{CH}_{4}$ RATIO OF 1.5

\begin{tabular}{|c|c|c|c|c|c|c|c|}
\hline \multirow{2}{*}{$\underset{(\mathrm{atm})}{\mathrm{p}}$} & \multirow{2}{*}{$\left(\begin{array}{c}t \\
\left({ }^{\circ} \mathrm{F}\right)\end{array}\right.$} & \multicolumn{4}{|c|}{ B.t.u/1b-mole input $\times 10^{-3}$} & \multirow[b]{2}{*}{ 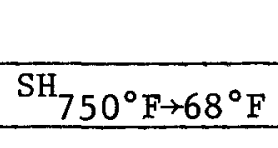 } & \multirow[b]{2}{*}{$\Delta \mathrm{H}_{\text {total }}$} \\
\hline & & $\mathrm{SH}_{68^{\circ} \mathrm{F} \rightarrow \mathrm{t}}$ & $\Delta \mathrm{H}_{\text {reformer }}$ & $\mathrm{SH}_{\mathrm{t} \rightarrow 750^{\circ} \mathrm{F}}$ & $\Delta \mathrm{H}_{\text {shift }}$ converter & & \\
\hline 5 & 1200 & 11.653 & 15.084 & -5.623 & -0.890 & -7.675 & 12.549 \\
\hline 5 & 1600 & 16.793 & 35.565 & -11.593 & -1.824 & -8.823 & 30.118 \\
\hline 5 & 1800 & 22.463 & 38.772 & -17.404 & -1.904 & -8.965 & 32.962 \\
\hline 40 & 1200 & 11.653 & 6.338 & -5.376 & -0.228 & -7.029 & 5.358 \\
\hline 40 & 1600 & 16.793 & 20.444 & -11.123 & -1.752 & -7.980 & 16.382 \\
\hline 40 & 1800 & 22.463 & 36.031 & $-17 \cdot 318$ & -2.076 & -8.829 & 30.271 \\
\hline
\end{tabular}




\section{REFERENCES}

1. J. F. Dent, L. A. Moignard, W. H. Blackbraun, and D. Herbden, "An Investigation into the Catalytic Synthesis of Methane by Town Gas Manufacture," 49th report of the Joint Research Committee of the Gas Research Board and the University of Leeds, GRB20 (1945).

2. M. Greyson, J. J. Dementer, M. D. Schlesinger, G, E. Johnson, J. Jonakin, and J. W. Myers, "Synthesis of Methane," U. S. Bur. Mines Bu11. RI 5137 (1955).

3. (a) G. Gruber, "Equilibrium Considerations in the Methane Synthesis System," Amer. Chem. Soc. Div. Fuel Chem. Prepr. 19 (3), 117 (1974).

(b) G. Gruber, Private Communication

4. P. Wellman and S. Kate11, Hydrocarbon Processing and Petroleum Refiner 42 (6), 135 (1963).

5. All thermodynamic data, except for Dent carbon (ref. 3(b), used in this report were taken from the Joint Army-Navy-Air Force Thermochemical Tables. 2nd ed., Nat. Bur. Stand. Ref. Data Ser., Nat. Bur. Stand. (U. S.), 37 (June 1971).

6. H. Margenau and G. M. Murphy, "The Mathematics of Physics and Chemistry," D. Van Nostrand Co., Inc. New York (1956), p. 492.

7. A. Ralston and H. S. Wilf, Mathematical Methods of Digital Computers (ed.), John Wiley and Sons, Inc., New York, 1960, p. 39.

This report is based on a thesis by Li-hua Wu presented to the Department of Chemistry of the University of Tennessee in partial fulfillment of the requirements for the M.S. degree, August 1976. 


\section{APPENDIX}

A listing of the FORTRAN program written to carry out the calculations for either methane synthesis or steam-methane reforming follows. Definitions of the variables which comprise the input to the program are given in the comment statements at the beginning of the program. For either methane synthesis or steam-methane reforming these variables are input on two cards per case according to the format shown in Table VIII. A blank card following the last case terminates the calculations

The temperatures on card 2 for either steam-methane reforming or methane synthesis may be in degrees Fahrenheit, degrees Centigrade, or degrees Kelvin. 
TABLE VIII. INPUT DATA

\begin{tabular}{|c|c|c|c|}
\hline Card No. & Field & Variable & Format \\
\hline \multirow[t]{11}{*}{1} & $1-10$ & $\mathrm{P}$ & $\mathrm{E} 10.0$ \\
\hline & $11-20$ & $\mathbf{R}$ & $\mathrm{E} 10.0$ \\
\hline & $21-30$ & $\mathrm{XI}$ & $\mathrm{E} 10.0$ \\
\hline & $31-40$ & $\mathrm{YI}$ & E10.0 \\
\hline & $41-50$ & ZI & E10.0 \\
\hline & $51-60$ & EPS & $\mathrm{E} 10.0$ \\
\hline & $61-65$ & NIT & I5 \\
\hline & $66-70$ & NSC & I5 \\
\hline & $71-75$ & NMETH & I5 \\
\hline & 76 & $\mathrm{NDC}$ & I1 \\
\hline & $77-80$ & NTC & 14 \\
\hline \multirow[t]{6}{*}{2} & \multicolumn{3}{|c|}{ (for steam methane reforming) } \\
\hline & $1-10$ & $\mathrm{~T} 1$ & E10.0 \\
\hline & $11-20$ & $\mathrm{~T} 2$ & $\mathrm{E} 10.0$ \\
\hline & $21-30$ & T3 & E10.0 \\
\hline & $31-40$ & $\mathrm{~T} 4$ & E10.0 \\
\hline & $41-50$ & T5 & E10.0 \\
\hline \multirow[t]{4}{*}{2} & \multicolumn{3}{|c|}{ (for methane synthesis) } \\
\hline & $1-10$ & $\mathrm{~T} 1$ & E10.0 \\
\hline & $11-20$ & $\mathrm{~T} 2$ & E10.0 \\
\hline & $21-30$ & $\mathrm{~T} 3$ & E10.0 \\
\hline
\end{tabular}




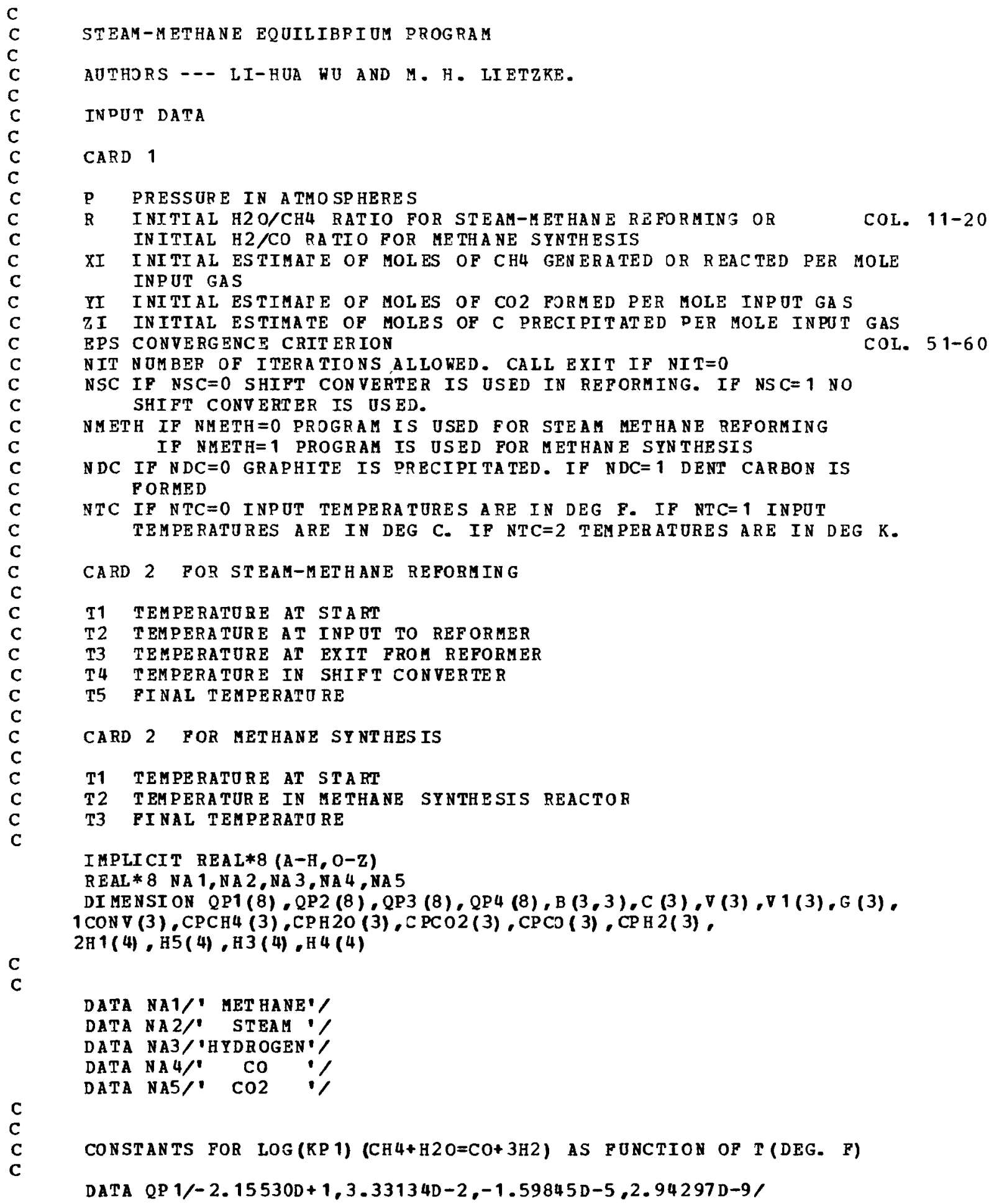




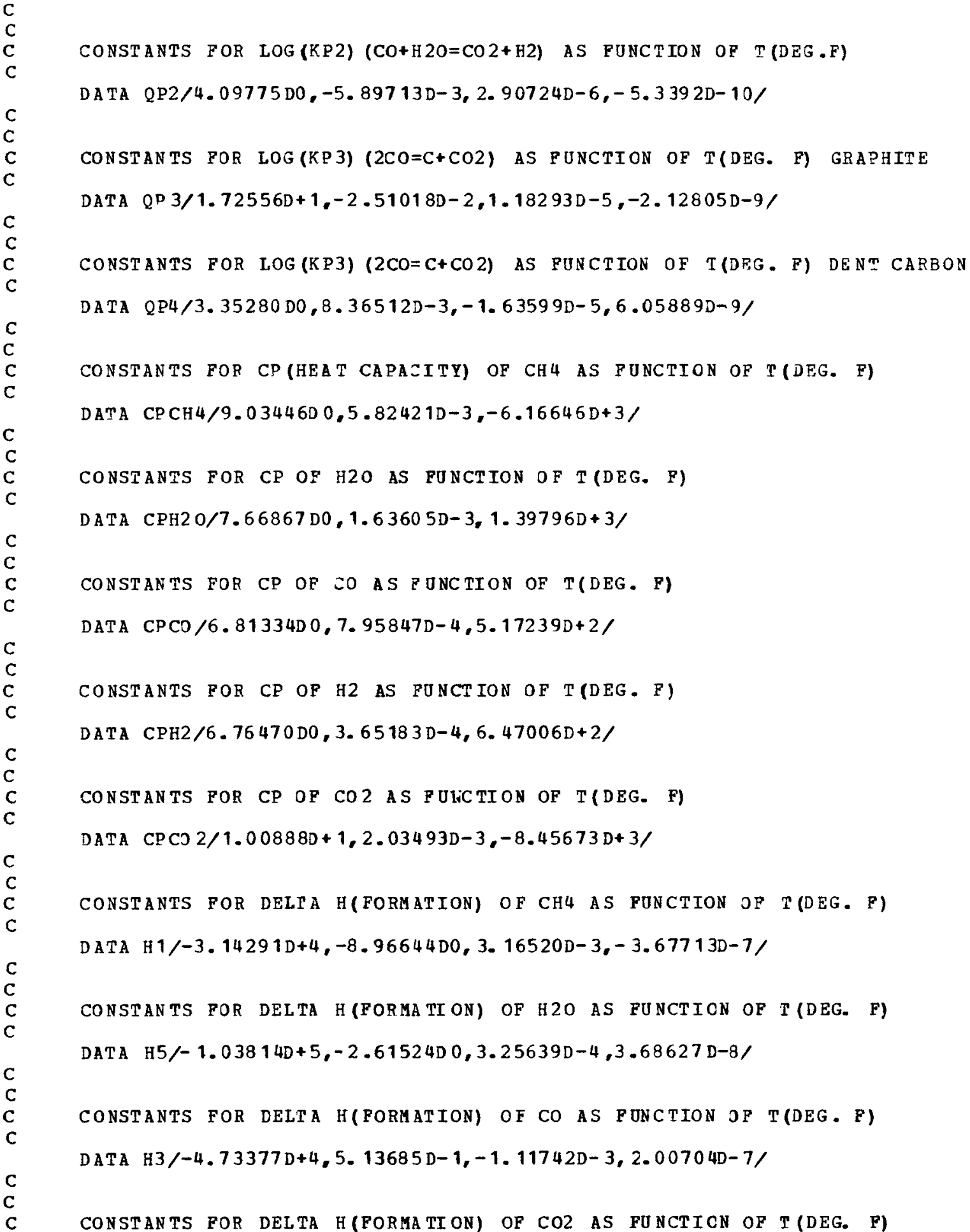


c

C

C

c

C

C

c

C

C

C

C

C

C

C

C

C

C

C

C

DATA H $4 /-1.69105 \mathrm{D}+5,-5.0 \mathrm{D}-1,-1.03398 \mathrm{D}-25,2.52435 \mathrm{D}-29 /$

FUNCTIJNS AND DERIVATI VES POR STEAM-METHANE REFORMING WITH C-PPT

$F 1 C(Q 1, P, A, X, Y, Z)=21 *(1,-A-X) *(A-X-Y+Z) *(1,+2 . * X-Z) * 2-(X-Y-Z) *(3$ $1 * \mathrm{X}+\mathrm{Y}-\mathrm{Z}) * * 3 * \mathrm{P} * * 2$

$F 2 C(Q 2, A, X, Y, Z)=Q 2 *(X-Y-Z) *(A-X-Y+Z)-Y *(3 . * X+Y-Z)$

$\mathrm{F} 3 \mathrm{C}(\mathrm{Q} 3, \mathrm{P}, \mathrm{X}, \mathrm{Y}, \mathrm{Z})=\mathrm{Q} 3 *(\mathrm{X}-\mathrm{Y}-\mathrm{Z}) * 2 * \mathrm{P}-\mathrm{Y} *(1,+2 . * \mathrm{X}-\mathrm{Z})$

$\operatorname{DF} 1 \mathrm{CX}(Q 1, D, A, X, Y, Z)=-Q 1 *(A-X-Y+Z) *(1,+2, X-Z) * 2-C 1 *(1,-A-X) *(1 .+2$ $1 . * \mathrm{X}-\mathrm{Z}) * 2+4 . * \mathrm{Q} 1 *(1 .-\mathrm{A}-\mathrm{X}) *(\mathrm{~A}-\mathrm{X}-\mathrm{Y}+\mathrm{Z}) *(1 .+2 . * \mathrm{X}-\mathrm{Z})-(3 . * \mathrm{X}+\mathrm{Y}-\mathrm{Z}) * 3 * \mathrm{P} * 2-$ 29.*(X-Y-Z)*(3.*X+Y-Z)**2*P*2

$\operatorname{DF} 1 \mathrm{CY}(\mathrm{Q} 1, \mathrm{P}, \mathrm{A}, \mathrm{X}, \mathrm{Y}, \mathrm{Z})=-\mathrm{Q} 1 *(1,-\mathrm{A}-\mathrm{X}) *(1,+2, * \mathrm{X}-\mathrm{Z}) * 2 * 2+(3 . * \mathrm{X}+\mathrm{Y}-\mathrm{Z}) * 3 * \mathrm{Z} * 2$ $1-3 . *(\mathrm{X}-\mathrm{Y}-\mathrm{Z}) *(3 . * \mathrm{X}+\mathrm{Y}-\mathrm{Z}) * * 2 * \mathrm{P} * * 2$

$\operatorname{DF} 1 C Z(Q 1, P, A, X, Y, Z)=Q 1 *(1,-A-X) *(1,+2 . * X-Z) * 2-2 . * Q 1 *(1,-A-X) *(A-X$

$1-Y+Z) *(1 .+2 . * X-Z)+(3 . * X+Y-Z) * * 3 * P * * 2+3 . *(X-Y-Z) *(3 . * X+Y-Z) * * 2 * P * * 2$ $D F 2 C X(Q 2, A, X, Y, Z)=Q 2 *(A-X-Y+Z)-Q 2 *(X-Y-Z)-3 . * Y$

DF $2 C Y(Q 2, A, X, Y, Z)=-22 *(A-X-Y+Z)-Q 2 *(X-Y-Z)-(3 . * X+Y-Z)-Y$

$\mathrm{DF} 2 \mathrm{CZ}(\mathrm{QZ}, \mathrm{A}, \mathrm{X}, \mathrm{Y}, \mathrm{Z})=-\mathrm{Q} 2 *(\mathrm{~A}-\mathrm{X}-\mathrm{Y}+\mathrm{Z})+\mathrm{Q} 2 *(\mathrm{X}-\mathrm{Y}-\mathrm{Z})+\mathrm{Y}$

$D F 3 C X(Q 3, P, X, Y, Z)=2 . * Q 3 *(X-Y-Z) * P-2 . * Y$

DF $3 C Y(Q 3, P, X, Y, Z)=-2 . * Q 3 *(X-Y-Z) * P-(1 .+2 . * X-Z)$

$D F 3 C Z(Q 3, P, X, Y, Z)=-2 * Q 3 *(X-Y-Z) * P+Y$

FUNCTIONS AND DERIVATI VES FOR STEAM-METHANE REPORMING WITHOUI C-PPT

$P 1(Q 1, P, A, X, Y)=Q 1 *(1,-A-X) *(A-X-Y) *(1 .+2 . * X) * * 2-(X-Y) *(3 . * X+Y) * 3 *$ $1 \mathrm{P} * 2 * 2$

$F 2(Q 2, A, X, Y)=Q 2 *(X-Y) *(A-X-Y)-Y *(3, * X+Y)$

$\mathrm{DF} 1 \mathrm{X}(\mathrm{Q} 1, \mathrm{P}, \mathrm{A}, \mathrm{X}, \mathrm{Y})=-\mathrm{Q} 1 *(\mathrm{~A}-\mathrm{X}-\mathrm{Y}) *(1 .+2 . * X) * 2-Q 1 *(1 .-A-X) *(1 .+2 . * X) * 2$ $1+4 . * Q 1 *(1 .-A-X) *(A-X-Y) *(1 .+2 . * X)-(3 . * X+Y) * 3 * F * 2-9 *(X-Y) *(3 . * X+$ $2 \mathrm{\eta} * * 2 * \mathrm{P} * * 2$

DF1 $Y(Q 1, P, A, X, Y)=-Q 1 *(1 .-A-X) *(1 .+2 . * X) * 2+(3 . * X+Y) * 3 * P * 2-3 . *(X-$ 1Y) $*(3 . * *+Y) * * 2 * \mathrm{P} * * 2$

$D F 2 X(Q 2, A, X, Y)=Q 2 *(A-X-Y)-Q 2 *(X-Y)-3 . * Y$

DF $2 Y(Q 2, A, X, Y)=-Q 2 *(A-X-Y)-Q 2 *(X-Y)-(3 . * X+Y)-Y$

FUNCTIONS AND DERIVATIVES OF REACTIONS IN SHIFT CONVERTER WITH C-PPT $\mathrm{F} 2 \mathrm{CSC}(\mathrm{Q} 2, \mathrm{~A}, \mathrm{Y}, \mathrm{Z}, \mathrm{CO}, \mathrm{H} 2, \mathrm{CO} 2)=\mathrm{Q} 2 *(\mathrm{CO}-\mathrm{Y}-\mathrm{Z}+\mathrm{CO} 2) *(\mathrm{~A}-\mathrm{Y}+\mathrm{CO} 2+\mathrm{Z})-\mathrm{Y} *(\mathrm{H} 2+\mathrm{Y}-\mathrm{CO} 2-$ 12)

$\mathrm{P} 3 \operatorname{Csc}(Q 3, A, P, Y, Z, C O, H 2, \operatorname{CO} 2)=Q 3 *(\mathrm{CO}-\mathrm{Y}-\mathrm{Z}+\mathrm{CO} 2) * 2 * \mathrm{P}-\mathrm{Y} *(\mathrm{~A}+\mathrm{CO} 2+\mathrm{CO}+\mathrm{H} 2-\mathrm{Z})$

$\operatorname{DF} 2 \operatorname{Cs} Y(Q 2, A, Y, Z, C O, H 2, \operatorname{CO} 2)=-Q 2 *(A-Y+\operatorname{CO} 2+Z)-Q 2 *(\mathrm{CO}-\mathrm{Y}-\mathrm{Z}+\mathrm{CO} 2)-(\mathrm{H} 2+\mathrm{Y}-$ $1 \mathrm{CO} 2-\mathrm{Z})-\mathrm{Y}$

DF $2 \operatorname{CSZ}(Q 2, A, Y, Z, C O, Z 02)=-Q 2 *(A-Y+C O 2+Z)+Q 2 *(C O-Y-Z+C O 2)+Y$

$\mathrm{DF} 3 \mathrm{CS} Y(\mathrm{Q} 3, \mathrm{~A}, \mathrm{P}, \mathrm{Y}, \mathrm{Z}, \mathrm{CO}, \mathrm{H} 2, \mathrm{CO} 2)=-2, \mathrm{Q} 3 *(\mathrm{CO}-\mathrm{Y}-\mathrm{Z}-\mathrm{CO} 2) * \mathrm{P}-(\mathrm{A}+\mathrm{CO} 2+\mathrm{CO}+\mathrm{H} 2-\mathrm{Z})$

$\operatorname{DF} 3 \operatorname{CsZ}(Q 3, P, Y, Z, C O, C 02)=-2 . Q 3 *(C O-Y-Z-C O 2) * P+Y$

ALL SENSI BLE HEATS IN ETO/ (LB-MOLE) 
C

C

C

C

C

C

c

C

C

C$$
\mathrm{C}
$$$$
\text { C }
$$$$
c
$$$$
\text { C }
$$$$
\text { C }
$$

C

C

C

c

C

C

C

C

C

C

C

c

C

C

c

C

SENSI BLE HEAT FOR METHANE OVER TEMPERATURE RANGE T1 TO T2(DEG. F) $\mathrm{SHCH}_{4}(\mathrm{~T} 2, \mathrm{~T} 1)=\mathrm{CPCH} 4(1) *(\mathrm{~T} 2-\mathrm{T} 1)+\mathrm{CPCH} 4(2) / 2 * *(\mathrm{~T} 2 * 2-\mathrm{T} 1 * 2)-\mathrm{CPCH}_{4}(3) *$ $1(1 . / T 2-1 . / T 1)$

SENSI BLE HEAT FOR STEAM OVZR TEMPERATURE RANGE T1 TO T2 (DEg. $\mathrm{SH} 2 \mathrm{O}(\mathrm{T} 2, \mathrm{~T} 1)=\mathrm{CPH} 2 \mathrm{O}(1) *(\mathrm{~T} 2-\mathrm{T} 1)+\mathrm{CPH} 2 \mathrm{O}(2) / 2 . *(\mathrm{~T} 2 * * 2-\mathrm{T} 1 * * 2)-\mathrm{CPH} 2 \mathrm{O}(3) *$ $1(1 . / T 2-1 . / T 1)$

SENSIBLE HEAT FOR CARBON MONOXIDE OVER TEMPERATURE RANGE T1 TO T2(DEG. F) $\mathrm{SHCO}(\mathrm{T} 2, \mathrm{~T} 1)=\mathrm{CPCO}(1) *(\mathrm{~T} 2-\mathrm{T} 1)+\mathrm{CPCO}(2) / 2 . *(\mathrm{~T} 2 * 2-\mathrm{T} 1 * 2)-\mathrm{CPCO}(3) *$ $1(1 . / T 2-1 . / T 1)$

SENSI BLE HEAT FOR HYDROGEN OVER TEMPERATURE BANGE T1 TO T2 (DEG. E) SHH $2(\mathrm{~T} 2, \mathrm{~T} 1)=\mathrm{CPH} 2(1) *(\mathrm{~T} 2-\mathrm{T} 1)+\mathrm{CPH} 2(2) / 2 . *(\mathrm{~T} 2 * 2-\mathrm{T} 1 * 2)-\mathrm{CPH} 2(3) *$ $1(1 . / T 2-1 . / T 1)$

SENSible hEAT FOR CaRBon DIOXIDE OVER TEMPERATURE RANGE T1 TO T2 (DEG. F) $\mathrm{SHCO} 2(\mathrm{~T} 2, \mathrm{~T} 1)=\mathrm{CPCO} 2(1) *(\mathrm{~T} 2-\mathrm{T} 1)+\mathrm{CPCO} 2(2) / 2 . *(\mathrm{~T} 2 * 2-\mathrm{T} 1 * 2)-2 \mathrm{PCO} 2(3) *$ $1(1 . / m 2-1 . / T 1)$

LOG (EQUILIBRIOM CONSTANT) FOR REACTION 1 (CH4+H2D=CO+3H2) A T T (DEG. P) QPI $1(T)=Q P 1(1)+Q P 1(2) * T+Q P 1(3) * T * * 2+Q P 1(4) * T * 3$

LOG(EQUILIBRIUM CONSTANT) FOR REACTION $2(\mathrm{CO}+\mathrm{H} 2 \mathrm{O}=\mathrm{CC} 2+\mathrm{H} 2)$ AT T(DEG. F) $Q P I 2(T)=2 P 2(1)+Q P 2(2) * T+Q P 2(3) * T * * 2+Q P 2(4) * T * 3$

LOG (E QUILIBRIU M CONSTANT) FOR REACTION $3(2 \mathrm{CO}=\mathrm{C}+\mathrm{CO} 2)$ AT T(DEG. F) GRAPHITE $Q P I 3(T)=Q P 3(1)+Q P 3(2) * T+Q P 3(3) * T * * 2+Q P 3(4) * T * 3$

LOG (EQUIL IBRIUM CONSTANT) FOR REACIION $3(2 \mathrm{CO}=\mathrm{C}+\mathrm{CO})$ AT I (DEG. F) DENT C $Q P T 4(T)=Q P 4(1)+Q P 4(2) * T+Q P 4(3) * T * 2+Q P 4(4) * T * 3$

ALL HEATS OF FORMATION IN BTU/(LB-MOLE)

HEAT OF PORMATION OF CH4 AT T (DEG. F) $\mathrm{HCH} 4(\mathrm{~T})=\mathrm{H} 1(1)+\mathrm{H} 1(2) * \mathrm{~T}+\mathrm{H} 1(3) * \mathrm{~T} * * 2+\mathrm{H} 1(4) * \mathrm{~T} * * 3$

HEAT OF FORMATION OF H 20 AT T (DEG. F) 
C

C

C

C

$\mathrm{C}$

$\mathrm{C}$

C

C

C

C

C

C

C

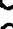

C

$\mathrm{HH} 2 \mathrm{O}(\mathrm{T})=\mathrm{H} 5(1)+\mathrm{H} 5(2) * \mathrm{~T}+\mathrm{H} 5(3) * \mathrm{~T} * * 2+\mathrm{H} 5(4) * \mathrm{~T} * 3$

HEAT OF FORMATION OP CO AT T (DEG. F) $\mathrm{HCO}(\mathrm{T})=\mathrm{H} 3(1)+\mathrm{H} 3(2) * \mathrm{~T}+\mathrm{H} 3(3) * \mathrm{~T} * 2 * \mathrm{H} 3(4) * \mathrm{~T} * 3$

HEAT OF FORMATION OF CO2 AT T(DEG. F)

$\mathrm{HCO} 2(\mathrm{~T})=\mathrm{H} 4(1)+\mathrm{H} 4(2) * \mathrm{~T} * \mathrm{H} 4(3) * \mathrm{~T} * * 2+\mathrm{H} 4(4) * \mathrm{~T} * * 3$

PONCTIONS AND DERIVATIVES OF METHANE SYNTHESIS VITH C-PPT

PI $(Q 1, P, A, X, Y, Z)=Q 1 *(A-3 . * X+Y-Z) * * 3 *(1 .-A-X-Y-Z) * P * * 2-X *(X-Y+Z) *$ $1(1 .-2 . * \mathrm{X}-\mathrm{Z}) * * 2$

$P J(Q 2, A, X, Y, Z)=Q 2 *(1,-A-X-Y-Z) *(X-Y+Z)-Y *(A-3 . * X+Y-Z)$

$F K(Q 3, P, A, X, Y, Z)=Q 3 *(1 .-A-X-Y-Z) * 2 * P-Y *(1 .-2 . * X-Z)$

PPIX $(Q 1, P, A, X, Y, Z)=-9 . * Q 1 *(A-3 . * X+Y-Z) * * 2 *(1 .-A-X-Y-Z) * P * 2-Q 1 *$

$1(A-3 . * X+Y-Z) * * 3 * P * * 2-(X-Y+Z) *(1 .-2 . * X-Z) * * 2-X *(1 .-2 . * X-Z) * * 2+4 . * X *$

$2(X-Y+Z) *(1 .-2 . * X-Z)$

$\operatorname{DFIY}(Q 1, P, A, X, Y, Z)=3 . * Q 1 *(A-3 . * X+Y-Z) * * 2 *(1 .-A-X-Y-Z) * P * * 2-Q 1 *$

$1(A-3 . * X+Y-Z) * * 3 * P * * 2+X *(1 .-2 . * X-Z) * * 2$

$\mathrm{DPIZ}(\mathrm{Q} 1, \mathrm{P}, \mathrm{A}, \mathrm{X}, \mathrm{Y}, \mathrm{Z})=-3 . * \mathrm{Q} 1 *(\mathrm{~A}-3, * \mathrm{X}+\mathrm{Y}-\mathrm{Z}) * 2 *(1,-\mathrm{A}-\mathrm{X}-\mathrm{Y}-\mathrm{Z}) * \mathrm{P} * * 2-\mathrm{Q} 1 *$

$1(A-3 . * X+Y-Z) * * 3 * P * * 2-X *(1 .-2 . * X-Z) * * 2+2 . * X *(X-Y+Z) *(1 .-2 . * X-Z)$

$\operatorname{DFJX}(Q 2, A, X, Y, Z)=-Q 2 *(X-Y+Z)+Q 2 *(1 .-A-X-Y-Z)+3 . * Y$

$D P J Y(Q 2, A, X, Y, Z)=-Q 2 *(X-Y+Z)-Q 2 *(1,-A-X-Y-Z)-(A-3 . * X+Y-Z)-Y$

DFJZ $(Q 2, A, X, Y, Z)=-Q 2 *(X-Y+Z)+Q 2 *(1,-A-X-Y-Z)+Y$

$\mathrm{DPKX}(\mathrm{Q} 3, \mathrm{P}, \mathrm{A}, \mathrm{X}, \mathrm{Y}, \mathrm{Z})=-2 . * \mathrm{Q} 3 *(1,-\mathrm{A}-\mathrm{X}-\mathrm{Y}-\mathrm{Z}) * \mathrm{P}+2 . * \mathrm{Y}$

$\operatorname{DPKY}(Q 3, P, A, X, Y, Z)=-2 . * Q 3 *(1,-A-X-Y-Z) * P-(1,-2, * X-Z)$

$D P K Z(Q 3, P, A, X, Y, Z)=-2, * Q 3 *(1,-A-X-Y-Z) * P+Y$

PUNCTIONS AND DERIVATI VES OF METHANE STNTHESIS NITHOUT C-PPT

$P 11(Q 1, P, A, X, Y)=Q 1 *(A-3 . * X+Y) * 3 *(1 .-A-X-Y) * P * * 2-X *(X-Y) *(1 .-2 . * X)$ $1 * * 2$

$F 22(Q 2, A, X, Y)=Q 2 *(1,-A-X-Y) *(X-Y)-Y *(A-3, * X+Y)$

$\mathrm{DF} 11 \mathrm{X}(\mathrm{Q} 1, \mathrm{P}, \mathrm{A}, \mathrm{X}, \mathrm{Y})=-9 . * Q 1 *(\mathrm{~A}-3 . * \mathrm{X}+\mathrm{Y}) * * 2 *(1 .-\mathrm{A}-\mathrm{X}-\mathrm{Y}) * \mathrm{P} * * 2-Q 1 *(\mathrm{~A}-3 . * \mathrm{X}+$

1Y $* * 3 * \mathrm{P} * * 2-(X-Y) *(1,-2 . * X) * * 2-X *(1,-2 . * X) * * 2+4 . * X *(X-Y) *(1 .-2 . * X)$

$D P 11 Y(Q 1, P, A, X, Y)=3, * Q 1 *(A-3 . * X+Y) * * 2 *(1 .-A-X-Y) * P * * 2-Q 1 *(A-3 . * X+Y$ $1) * * 3 * P * * 2+X *(1,-2 . * x) * * 2$

$D P 22 X(Q 2, A, X, Y i=-Q 2 *(X-Y)+Q 2 *(1,-A-X-Y)+3 . * Y$

$D F 22 Y(Q 2, A, X, Y)=-Q 2 *(X-Y)-Q 2 *(1 .-A-X-Y)-(A-3 . * X+Y)-Y$

50 READ 2, P, P, XI, YI, ZI, EP S, NI T, NSC, NMETH, NDC, NTC

2 PORMAT (6E 10.0, 3I $5, I 1, I 4)$

IF (NIT $T$ EQ. O) CALI EX IT

$A=R /(1,+R)$

IF (MTC . EQ. 1) GO TO 20 
c

IF (NTC .EO. 2) GO TO 22

C

READ 1, T1,T2,T3,T4,T5

1 FORMAT ( 8E 10.0)

$\mathrm{T} 1 \mathrm{C}=(\mathrm{T} 1-32) * .5 . / 9$.

$\mathrm{T} 2 \mathrm{C}=(\mathrm{T} 2-32) *$.5.19 .

$T 3 C=(T 3-32) * .5 . / 9$.

$T 4 C=(T 4-32) * .5 . / 9$.

$\mathrm{T} 5 \mathrm{C}=(\mathrm{T} 5-32) * .5 . / 9$.

$\mathrm{T} 1 \mathrm{~K}=\mathrm{T} 1 \mathrm{C}+273.15$

$\mathrm{T} 2 \mathrm{~K}=\mathrm{T} 2 \mathrm{C}+273.15$

$\mathrm{T} 3 \mathrm{~K}=\mathrm{T} 3 \mathrm{C}+273.15$

$\mathrm{T} 4 \mathrm{~K}=\mathrm{T} 4 \mathrm{C}+273.15$

$\mathrm{T} 5 \mathrm{~K}=\mathrm{T} 5 \mathrm{C}+273.15$

GO TO 21

C

20 READ 1, T1C, T2C, T3C, T4C, T5C

C

$\mathrm{T} 1=\mathrm{T} 1 \mathrm{C} * 9 \cdot / 5 \cdot+32$.

$\mathrm{T} 2=\mathrm{T} 2 \mathrm{C} * 9 \cdot / 5++32$.

T $3=\mathrm{T} 3 \mathrm{C} * 9 \cdot / 5 \cdot+32$.

$\mathrm{T} 4=\mathrm{T} 4 \mathrm{C} * 9 \cdot / 5 \cdot+32$.

T $5=T 5 C * 9 \cdot / 5 \cdot+32$.

$\mathrm{T} 1 \mathrm{~K}=\mathrm{T} 1 \mathrm{C}+273.15$

$\mathrm{T} 2 \mathrm{~K}=\mathrm{T} 2 \mathrm{C}+273.15$

$\mathrm{T} 3 \mathrm{~K}=\mathrm{T} 3 \mathrm{C}+273 \cdot 15$

$\mathrm{T} 4 \mathrm{~K}=\mathrm{T} 4 \mathrm{C}+273.15$

$\mathrm{T} 5 \mathrm{~K}=\mathrm{T} 5 \mathrm{C}+273.15$

C

GO TO 21

$\mathrm{C}$

22 READ 1,T1K,T2K,T3K,T4K,T5K

$\mathrm{T} 1 \mathrm{C}=\mathrm{T} 1 \mathrm{~K}-273.15$

$\mathrm{T} 2 \mathrm{C}=\mathrm{T} 2 \mathrm{~K}-273 \cdot 15$

$\mathrm{T} 3 \mathrm{C}=\mathrm{T} 3 \mathrm{~K}-273.15$

$\mathrm{T} 4 \mathrm{C}=\mathrm{T} 4 \mathrm{~K}-273 \cdot 15$

$\mathrm{T} 5 \mathrm{C}=\mathrm{T} 5 \mathrm{~K}-273.15$

$\mathrm{T} 1=\mathrm{T} 1 \mathrm{C} * 9 \cdot 15 \cdot+32$.

$\mathrm{T} 2=\mathrm{T} 2 \mathrm{C} * 9 . / 5 .+32$.

$\mathrm{T} 3=\mathrm{T} 3 \mathrm{C} * 9 . / 5+32$.

$\mathrm{T} 4=\mathrm{T} 4 \mathrm{C} * 9 \cdot / 5 \cdot+32$.

$\mathrm{T} 5=\mathrm{T} 5 \mathrm{C} * 9 . / 5 .+32$.

21 IF (NMETH EQ - 1) GO TO 1000

C

C

C

STEAM-METHANE REFORMING

$\mathrm{C}$

$\mathrm{X}=\mathrm{XI}$

$Y=Y I$

$\mathrm{Z}=\mathrm{ZT}$

$\mathrm{V}(1)=\mathrm{X}$

$V(2)=Y$

$\nabla(3)=2$

$\mathrm{SH} 1 \mathrm{CH} 4=\mathrm{SHCH} 4(\mathrm{~T} 2, \mathrm{~T} 1) *(1,-\mathrm{A})$

$\mathrm{SHCCH} 4=\mathrm{SH} 1 \mathrm{CH} 4 * 0.251996 \mathrm{DO}$

$\mathrm{SH} 1 \mathrm{H} 2 \mathrm{O}=\mathrm{SHH} 2 \mathrm{O}(\mathrm{T} 2, \mathrm{~T} 1) * \mathrm{~A}$ 


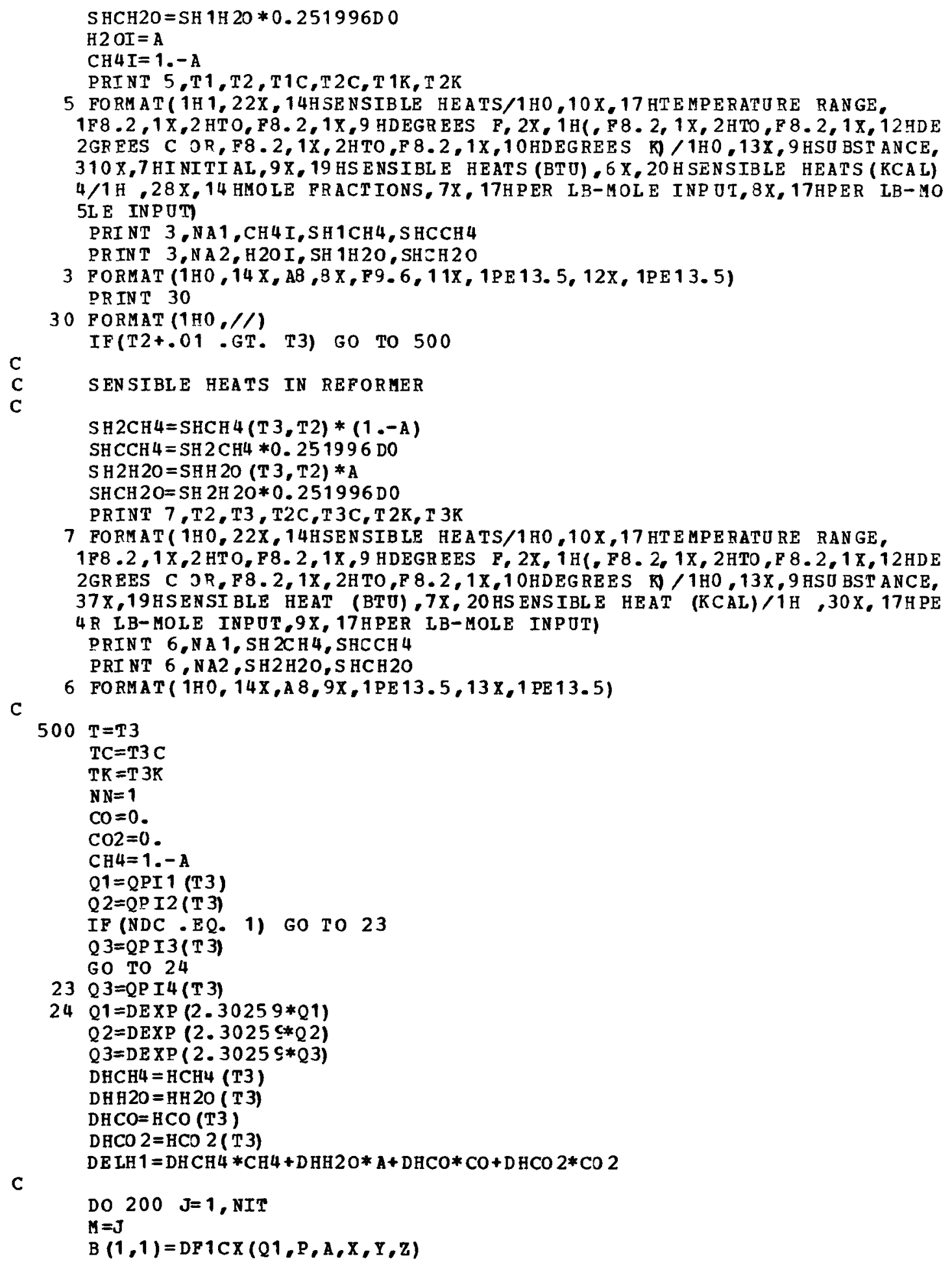




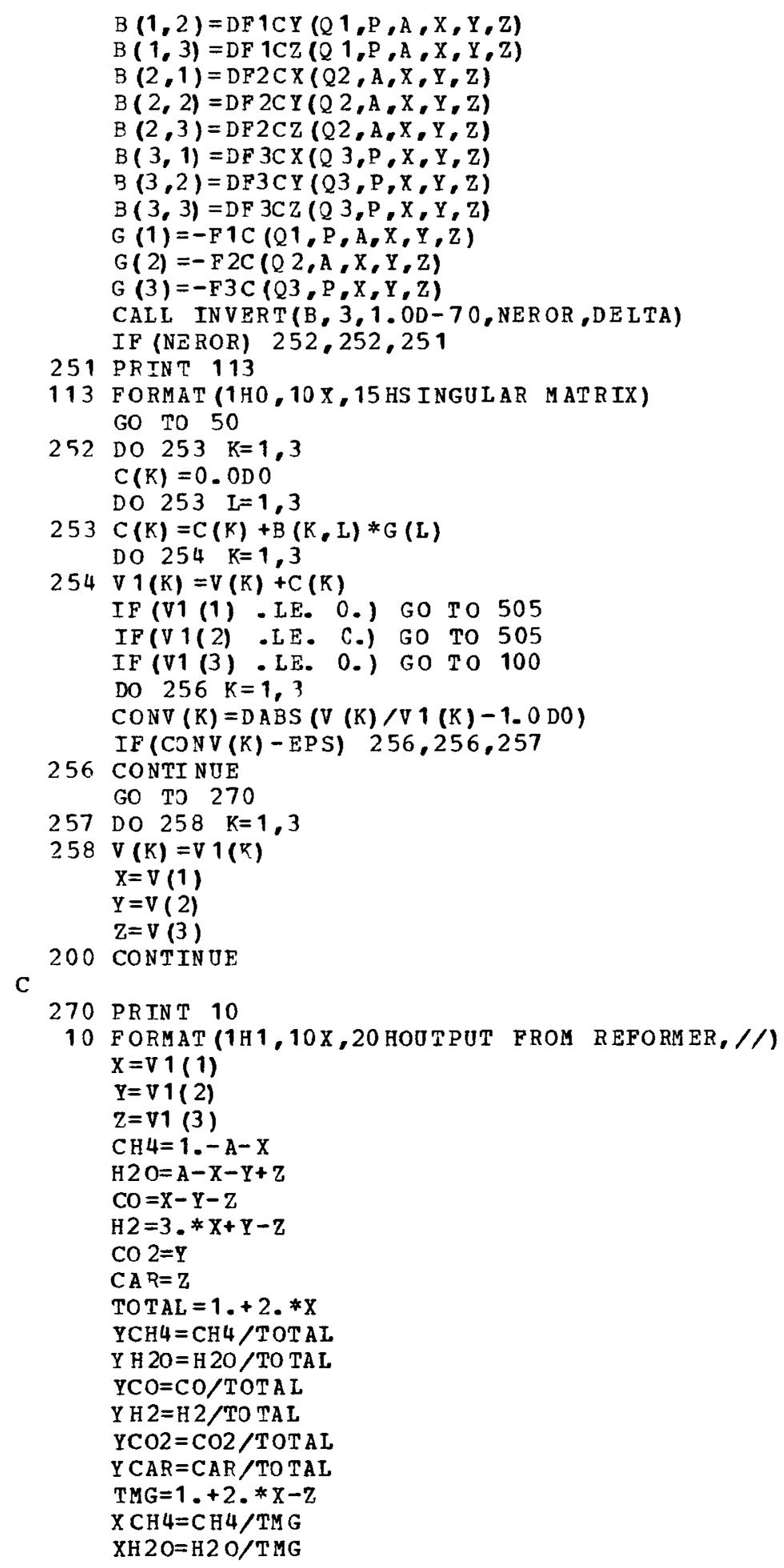


$\mathrm{XCO}=\mathrm{CO} / \mathrm{TMG}$

$\mathrm{XH} 2=\mathrm{H} 2 / \mathrm{TMG}$

$\mathrm{X} \mathrm{CO} 2=\mathrm{CO} 2 / \mathrm{TM} \mathrm{G}$

$\mathrm{XCAR}=0$.

$\mathrm{ZCAR}=\mathrm{CAR} / \mathrm{CH} 4 \mathrm{I}$

$\mathrm{EK} 1=(\mathrm{X}-\mathrm{Y}-\mathrm{Z}) *(3 . * \mathrm{X}+\mathrm{Y}-\mathrm{Z}) * 3 * \mathrm{P} * 2 /((1 .-\mathrm{A}-\mathrm{X}) *(\mathrm{~A}-\mathrm{X}-\mathrm{Y}+\mathrm{Z}) *(1 .+2 . \mathrm{X}-\mathrm{Z}) * 2)$

EK $2=\mathrm{Y} *(3 * \mathrm{X}+\mathrm{Y}-\mathrm{Z}) /((\mathrm{X}-\mathrm{Y}-\mathrm{Z}) *(\mathrm{~A}-\mathrm{X}-\mathrm{Y}+\mathrm{Z}))$

$\mathrm{EK} Z=\mathrm{Y} *(1 .+2 . * X-\mathrm{Z}) /((X-\mathrm{Y}-\mathrm{Z}) * 2 * \mathrm{P})$

PRINT 11

11 FORMAT(1H0, 13X,6HP (A TM), 5X, 8H T(DEG F), $5 \mathrm{X}, 8 \mathrm{HT}(\mathrm{DEG}$ C), $5 \mathrm{X}, 8 \mathrm{HT}(\mathrm{DEG} \mathrm{K})$, $15 X, 21 \mathrm{HINITIAL}$ H2O/CH4 RATIO)

PPIN T $12, \mathrm{P}, \mathrm{T}, \mathrm{TC}, \mathrm{TK}, \mathrm{R}$

12 FORMAT (1H0, F18.0,3F13.2, F20.3)

PR IN T 9000

9000 FORMAT $U / 11 \mathrm{HO}, 11 \mathrm{X}, 9$ HCOM PONENT, 5X, 20HMOLES PER MOLE INPUT, $11 \mathrm{X}, 14 \mathrm{H}$ MOL 1 E FRACTIONS, 5X,21HMOLE PRACTIONS IN GAS)

IF (NDC - EQ. 1) GO TO 218

PRIN T $215, \mathrm{CH} 4, \mathrm{YCH} 4, \mathrm{XCH} 4, \mathrm{H} 2 \mathrm{O}, \mathrm{YH} 2 \mathrm{O}, \mathrm{XH} 2 \mathrm{O}, \mathrm{CO}, \mathrm{YCO}, \mathrm{XCO}, \mathrm{H} 2, \mathrm{YH} 2, \mathrm{XH} 2, \mathrm{CO} 2$, $1 \mathrm{YCO} 2, \mathrm{XCO} 2, \mathrm{CAR}, \mathrm{YCAR}, \mathrm{XCAR}, \mathrm{ZCAR}$

215 FORMAT ( 1H0, 13X, 3HCH 4,3F 25.6/1H 0, 13X,3HH 20,3 F $25.6 / 1$ HO, 14X, 2 HCO, 3 F 25 $1.6 / 1 \mathrm{HO}, 14 \mathrm{X}, 2 \mathrm{HH} 2,3 \mathrm{~F} 25.6 / 1 \mathrm{HO}, 13 \mathrm{X}, 3 \mathrm{HCO} 2,3 \mathrm{~F} 25.6 / 1 \mathrm{HO}, 15 \mathrm{X}, 1 \mathrm{HC}, 3 \mathrm{~F} 25.6 / 1 \mathrm{H} 0$ $2 / 1 \mathrm{HO}, 11 \mathrm{X}, 41 \mathrm{HMOLE}$ FRACTION I NGOI NG CARBON DE FOSTTED = F8.6) GO TO 219

218 PRINT $217, \mathrm{CH} 4, \mathrm{YCH} 4, \mathrm{XCH} 4, \mathrm{H} 2 \mathrm{O}, \mathrm{YH} 2 \mathrm{O}, \mathrm{XH} 2 \mathrm{O}, \mathrm{CO}, \mathrm{YCO}, \mathrm{XCO}, \mathrm{H} 2, \mathrm{YH} 2, \mathrm{XH} 2, \mathrm{CO} 2$, $1 \mathrm{YCO} 2, \mathrm{XCO} 2, \mathrm{CAR}, \mathrm{YCAR}, \mathrm{XCAR}, \mathrm{ZCAR}$

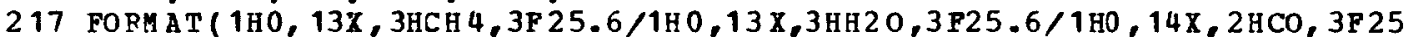
$1.6 / 1 \mathrm{H} 0,14 \mathrm{X}, 2 \mathrm{HH} 2,3 \mathrm{~F} 25.6 / 1 \mathrm{HU}, 13 \mathrm{X}, 3 \mathrm{HCO} 2,3 \mathrm{~F} 25.6 / 1 \mathrm{H} 0,10 \mathrm{X}, 6 \mathrm{HDENT}$ C. $3 \mathrm{~F} 25$. $26 / 1$ HO, 11X, 41HMOLE FRAC TION I NGOING CARBON DEPOSITED =,F8.6)

219 PRINT 15

15 FORMAT (1H0, 10X, 34HRECALC ULA TED EQUILI BRIUM CONSTANTS) PRI NT $16, \mathrm{EK} 1, \mathrm{EK2}, \mathrm{EK} 3$

16 FORMAT (1H $0,17 \mathrm{X}, 2 \mathrm{HK} 1,1 \mathrm{PE} 16.4 / 1 \mathrm{H} 0,17 \mathrm{X}, 2 \mathrm{HK} 2, \mathrm{E} 16.4 / 1 \mathrm{HO}, 17 \mathrm{X}, 2 \mathrm{HK} 3, \mathrm{E} 16.4)$ PRINT $17, M$

17 FORMAT ( $1 \mathrm{HO}, 10 \mathrm{X}, 12 \mathrm{H}$ こONVERGED IN,I5,11H ITERATIONS/ $/$

$A=A-X-Y+Z$

DELTA H $=\mathrm{DHCH} 4 * \mathrm{CH} 4+\mathrm{DHH} 20 * \mathrm{H} 20+\mathrm{DHCO} * \mathrm{CO}+\mathrm{DHCO} 2 * \mathrm{CO} 2-\mathrm{DELH} 1$ DELHC $=$ DELT A H*0.251996 DO

PR IN T 510

510 FORMAT (1H0,10X,21 HENTHALPY CHANGE (BTU), 5X, 22H EN THALPY CHANGE (KCa 11) $/ 1 \mathrm{H}, 12 \mathrm{X}, 17 \mathrm{HPER}$ LB-MOLE INP OT,9X,17HPER LB-MOLE INPUT) PRINT 511 , DELT AH, DELHC

511 FORMAT (1H0, 2(10X, 1PE 16.4)) GO TO 300

C

C

C

\section{STEAM-METHANE REFORMING NITHOOT C-PPT}

100 CONTI NOE

DO $60 \mathrm{~J}=1$, NIT

$M=J$

$B(1,1)=D F 1 X(Q 1, P, A, X, Y)$

$B(1,2)=D F 1 Y(Q 1, P, A, X, Y)$

$B(2,1)=D F 2 X(Q 2, A, X, Y)$

$B(2,2)=D F 2 Y(Q 2, A, X, Y)$

$G(1)=-F 1(Q 1, P, A, X, Y)$

$G(2)=-F 2(Q 2, A, X, Y)$

CALI I NVERT (B, 2,1.0 D-70, NEROR, DELTA)

IF (N EROR) $52,52,51$ 
51 PRINT 113

GO TO 50

52 DO $53 \quad K=1,2$

$C(K)=0.0 D 0$

DO $53 \mathrm{~L}=1,2$

$53 C(K)=C(K)+B(K, L) * G(L)$

DO $54 \quad K=1,2$

$54 \mathrm{~V} 1(K)=\mathrm{V}(\mathrm{K})+\mathrm{C}(\mathrm{K})$

DO $55 K=1,2$

IF (V1 (K) - GT. 0.) GO TO 55

PRINT 4, V1(1), V1 (2)

4 FORMAT $(1 \mathrm{HO}, 10 \mathrm{X}, 6 \mathrm{HCO} 2=, 0 \mathrm{PF} 7.4,10 \mathrm{X}, 6 \mathrm{HCH} 4=, \mathrm{F7} .4)$

GO TO 50

55 CONTINUE

DO $56 \mathrm{~K}=1,2$

$\operatorname{CONV}(K)=\mathrm{DABS}(\mathrm{V}(\mathrm{K}) / \mathrm{V} 1(\mathrm{~K})-1.0 \mathrm{D} 0)$

56 CONTINUE

GO TO 70

57 D O $58 \mathrm{~K}=1,2$

$58 \mathrm{~V}(\mathrm{~K})=\mathrm{V} 1(\mathrm{~K})$

$X=V(1)$

$\mathrm{Y}=\mathrm{V}(2)$

C

60 CONTINUE

70 PRINT 10

$X=V 1$ (1)

$\mathrm{Y}=\mathrm{V} 1$ (2)

CH $4=1 .-A-X$

$\mathrm{H} 2 \mathrm{O}=\mathrm{A}-\mathrm{X}-\mathrm{Y}$

$\mathrm{CO}=\mathrm{X}-\mathrm{Y}$

$\mathrm{H} 2=3$. $* X+Y$

$\mathrm{CO} 2=Y$

CA R $=0$.

TOTAL $=1 .+2 . * \mathrm{X}$

$\mathrm{YCH} 4=\mathrm{CH} 4 / \mathrm{TOT} A \mathrm{~L}$

Y H $20=\mathrm{H} 20 / \mathrm{TO}$ TAL

YCO $=\mathrm{CO} / \mathrm{TOT}$ A L

$Y \mathrm{H} 2=\mathrm{H} 2 / \mathrm{TO} \mathrm{TAL}$

$Y C 02=C 02 / T O T A L$

$\mathrm{YCAR}=\mathrm{CAR} / \mathrm{TO} \mathrm{TAL}$

$T M G=1 .+2 . * X$

$X \mathrm{CH} 4=\mathrm{CH} 4 / \mathrm{TMG}$

$\mathrm{XH} 2 \mathrm{O}=\mathrm{H} 2 \mathrm{O} / \mathrm{TMG}$

$\mathrm{XCO}=\mathrm{CO} / \mathrm{TM} \mathrm{G}$

$X \mathrm{H} 2=\mathrm{H} 2 / \mathrm{TMG}$

$X \mathrm{CO} 2=\mathrm{CO} 2 / \mathrm{TM} \mathrm{G}$

$X C A R=0$.

$E K 1=(X-Y) *(3 . * X+Y) * 3 * P * * 2 /((1 .-A-X) *(A-X-Y) *(1 .+2 . * X) * 2)$

$E K 2=Y *(3 . * X+Y) /((X-Y) *(A-X-Y))$

PRIN T 11

PRINT 12,P,T,TC,TK,R

PRINT 9000

IF (N DC . EQ . 1) GO TO 220

PRINT $214, \mathrm{CH}_{4}, \mathrm{YCH} 4, \mathrm{XCH} 4, \mathrm{H} 2 \mathrm{O}, \mathrm{YH} 2 \mathrm{O}, \mathrm{XH} 2 \mathrm{O}, \mathrm{CO}, \mathrm{YCO}, \mathrm{XCO}, \mathrm{H} 2, \mathrm{YH} 2, \mathrm{XH} 2, \approx \mathrm{O} 2$, $1 \mathrm{YCO} 2, \mathrm{XCO} 2, \mathrm{CAR}, \mathrm{YCAR}, \mathrm{XCAR}$

214 FORMAT (1H0, 13X, 3 HCH4, 3 F 25.6/1 HO, 13X, 3НH 2J, 3F $25.6 / 1 \mathrm{HO}, 14 \mathrm{X}, 2 \mathrm{HCO}, 3 \mathrm{~F} 25$

$1.6 / 1 \mathrm{H} 0,14 \mathrm{X}, 2 \mathrm{HH} 2,3 \mathrm{~F} 25.6 / 1 \mathrm{H} 0,13 \mathrm{X}, 3 \mathrm{HCO}, 3 \mathrm{~F} 25.6 / 1 \mathrm{HO}, 15 \mathrm{X}, 1 \mathrm{HC}, 3 \mathrm{~F} 25.6$ ) 
GO TO 221

220 PRINT $216, \mathrm{CH} 4, Y \mathrm{CH} 4, X \mathrm{CH} 4, \mathrm{H} 20, \mathrm{YH} 2 \mathrm{O}, \mathrm{XH} 20, \mathrm{CJ}, \mathrm{YCO}, \mathrm{XCO}, \mathrm{H} 2, \mathrm{YH} 2, \mathrm{XH} 2, \mathrm{CO} 2$, $1 Y \mathrm{CO} 2, \mathrm{XCO} 2, \mathrm{CAR}, \mathrm{YCAR}, \mathrm{XCAR}$

216 FORMAT (1H0, 13X, 3 HCH4, 3 F $25.6 / 1 \mathrm{HO}, 13 \mathrm{X}, 3 \mathrm{HH} 2 \mathrm{~J}, 3 \mathrm{~F} 25.6 / 1 \mathrm{H} 0,14 \mathrm{X}, 2 \mathrm{HCO}, 3 \mathrm{~F} 25$ $1.6 / 1 \mathrm{HO}, 14 \mathrm{X}, 2 \mathrm{HH} 2,3 \mathrm{~F} 25.6 / 1 \mathrm{HO}, 13 \mathrm{X}, 3 \mathrm{HCO}, 3 \mathrm{~F} 25.6 / 1 \mathrm{HO}, 10 \mathrm{X}, 6 \mathrm{HDENT}$ C, $3 \mathrm{~F} 25$. 26)

221 PRINT 15

PRINT $16, \mathrm{EK1}, \mathrm{BR2}$

PRINT $17, \mathrm{M}$

$V(1)=X$

$V(2)=Y$

$A=A-X-Y$

DELT TH H $=\mathrm{DHCH} 4 * \mathrm{CH} 4+\mathrm{DHH} 20 * \mathrm{H} 20+\mathrm{DHCO} * \mathrm{C} \mathrm{O}+\mathrm{DHCO} * \mathrm{CO} 2-\mathrm{DEIH} 1$

$\mathrm{DELHC}=\mathrm{DELTAH} * 0.251996 \mathrm{DO}$

PR TN T 510

C

PRINT 511, DELTAH, DELHC

C SHIPT CONVERTER

300 CONTI NUE

$\mathrm{SH} 3 \mathrm{CH} 4=\mathrm{SHCH} 4(\mathrm{~T} 4, \mathrm{~T}) * \mathrm{CH} 4$

$\mathrm{SHCCH} 4=\mathrm{SH} 3 \mathrm{CH} 4 * 0.251996 \mathrm{DO}$

$\mathrm{SH} 3 \mathrm{H} 2 \mathrm{O}=\mathrm{SHH} 2 \mathrm{O}(\mathrm{T} 4, \mathrm{~T}) * \mathrm{H} 2 \mathrm{O}$

$\mathrm{SHCH} 2 \mathrm{O}=\mathrm{SH} 3 \mathrm{H} 2 \mathrm{O} * 0.251996 \mathrm{DO}$

$\mathrm{SH} 3 \mathrm{CO} 2=\mathrm{SHCO} 2(\mathrm{~T} 4, \mathrm{~T}) * \mathrm{CO} 2$

$\mathrm{SHCCO} 2=\mathrm{SH} 3 \mathrm{CO} 2 * 0.251996 \mathrm{D} 0$

$\mathrm{SH} 3 \mathrm{CO}=\mathrm{SHCO}(\mathrm{T} 4, \mathrm{~T}) * \mathrm{CO}$

$\mathrm{SHCCO}=\mathrm{SH} 3 \mathrm{CO} * 0.251996 \mathrm{D} 0$

$\mathrm{SH} 3 \mathrm{H} 2=\mathrm{SHH} 2(\mathrm{~T} 4, \mathrm{~T}) * \mathrm{H} 2$

$\mathrm{SHCH} 2=\mathrm{SH} 3 \mathrm{H} 2 * 0.251996 \mathrm{DO}$

PRINT 8,T,T $4, T C, T 4 C, T K, T 4 K$

8 FORMAT ( $1 \mathrm{H} 1,22 \mathrm{X}, 14 \mathrm{HS}$ ENS IBLE HEATS/ 1 HO, 10X, 17 HTEMPERATURE RANGE,

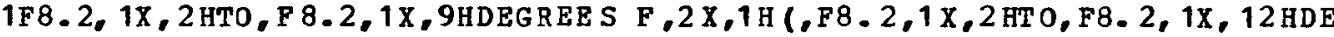

2GREES C OR, F8, 2, 1X, 2 HT 0, F8. 2, 1X, 10 HDEGREES K) 1 1H0,13X, 9H SUB STA NCE,

37X, 19HS EN SIBLE HEAT (B T 0),7X,20HSENSIBLE HEAT (KCAL)/1H, 30X, 17 HPE

4R LB-MOLE INPUT, 9X, 17HPER IB-HOLE INPUT)

PRINT $6, \mathrm{NA} 1, \mathrm{SH} 3 \mathrm{CH} 4, \mathrm{SHCCH} 4$

PRINT 6, NA 2, SH 3H2O, SHCH 20

PRI NT $6, \mathrm{NA} 3, \mathrm{SH} 3 \mathrm{H} 2, \mathrm{SHCH} 2$

PRIN T $6, \mathrm{NA}_{4}, \mathrm{SH} 3 \mathrm{CO}, \mathrm{SHCCO}$

PRINT $6, \mathrm{NA} 5, \mathrm{SH} 3 \mathrm{CO} 2, \mathrm{SHCCO} 2$

IF (NSC) $800,800,613$

800 DHH $2 \mathrm{O}=\mathrm{HH} 2 \mathrm{O}(\mathrm{T} 4)$

$\mathrm{DHCO}=\mathrm{HCO}(\mathrm{T} 4)$

$\mathrm{DHCO} 2=\mathrm{HCO} 2(\mathrm{~T} 4)$

DEL $\mathrm{H} 1=\mathrm{DHH} 2 \mathrm{O} * \mathrm{~A}+\mathrm{DHCO} * \mathrm{CO}+\mathrm{DHCO} 2 * \mathrm{CO} 2$

$\mathrm{Q} 2=\mathrm{QPI} 2(\mathrm{~T} 4)$

IF (N DC .EQ. 1) GO TO 25

Q $3=Q P I 3(T 4)$

GO TO 26

$25 \mathrm{Q} 3=\mathrm{QP}$ I $4(\mathrm{~T} 4)$

$26 Q 2=D E X P(2.30259 * Q 2)$

$Q 3=D E X P(2.3025 \mathrm{C} * Q 3)$

$Y=\mathrm{CO} 2$

$\mathbf{Z}=\mathbf{Z I}$

$V(1)=Y$

C

$\nabla(2)=0.0 \mathrm{DO}$ 


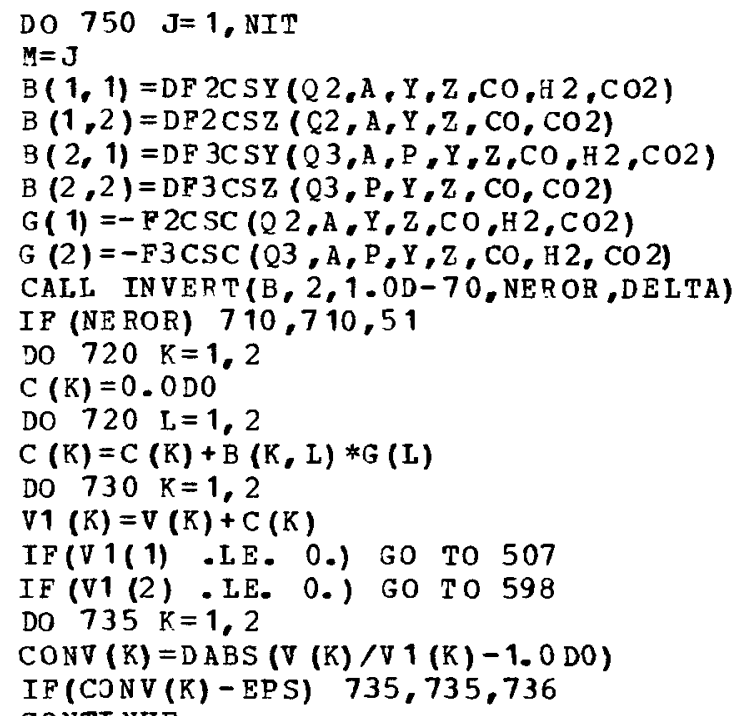

735 CONTI NUE

GO TO 760

736 DO $737 \mathrm{~K}=1,2$

$737 \mathrm{~V}(\mathrm{~K})=\mathrm{V} 1(\mathrm{~K})$

$\mathrm{Y}=\mathrm{V}(1)$

$z=V(2)$

C

750 CONTINUE

760 PRINT 610

$\mathrm{Y}=\mathrm{V} 1(1)$

$\mathrm{T}=\mathrm{V} 1(2)$

TOTAL $=\mathrm{A}+\mathrm{CO} 2+\mathrm{CO}+\mathrm{H} 2+\mathrm{CH} 4$

$\mathrm{TMG}=\mathrm{A}+\mathrm{CO} 2+\mathrm{CO}+\mathrm{H} 2-\mathrm{Z}+\mathrm{CH} 4$

$\mathrm{H} 2 \mathrm{O}=\mathrm{A}-\mathrm{Y}+\mathrm{CO} 2+\mathrm{Z}$

$\mathrm{CO}=\mathrm{CO}-\mathrm{Y}-\mathrm{Z}+\mathrm{CO}$ ?

$\mathrm{H} 2=\mathrm{H} 2+\mathrm{Y}-\mathrm{CO} 2-\mathrm{Z}$

$\mathrm{CO} 2=\mathrm{Y}$

$\mathrm{CAR}=\mathrm{Z}$

$\mathrm{YCH} 4=\mathrm{CH} 4 / \mathrm{TOTAL}$

$\mathrm{YH} 2 \mathrm{O}=\mathrm{H} 20 / \mathrm{TO}$ TAL

$\mathrm{YCO}=\mathrm{CO} / \mathrm{TOTAL}$

Y H $2=\mathrm{H} 2 / \mathrm{TO}$ TA L

$Y \mathrm{CO} 2=\mathrm{CO} 2 / \mathrm{TOT}$ AL

$\mathrm{YCAR}=\mathrm{CAR} / \mathrm{TO} \mathrm{TAL}$

$\mathrm{XCH}_{4}=\mathrm{CH} 4 / \mathrm{T} \mathrm{MG}$

$\mathrm{XH} 2 \mathrm{O}=\mathrm{H} 20 / \mathrm{TMG}$

$\mathrm{XCO}=\mathrm{CO} / \mathrm{TMG}$

$\mathrm{X}$ H $2=\mathrm{H} 2 / \mathrm{TMG}$

$\mathrm{XCO} 2=\mathrm{CO} 2 / \mathrm{T} M \mathrm{G}$

$\mathrm{XCAR}=0$.

$\mathrm{E} \mathrm{K} 2=\mathrm{CO} 2 * \mathrm{H} 2 /(\mathrm{CO} * \mathrm{H} 2 \mathrm{O})$

EK $3=\mathrm{Y} * \mathrm{TMG} /(\mathrm{CO} * 2 * \mathrm{P})$

DELTAH $=\mathrm{DH} H 2 O * \mathrm{H} 2 \mathrm{O}+\mathrm{DHCO} * \mathrm{CO}+\mathrm{DHCO} 2 * \mathrm{CO} 2-\mathrm{DEL} H 1$

$D E L$ HC $=D$ EL TA H*0.25 1996D 0

PRINT 11

PRINT 12, P, T4, T4C,T4K, R

PRINT 9000 


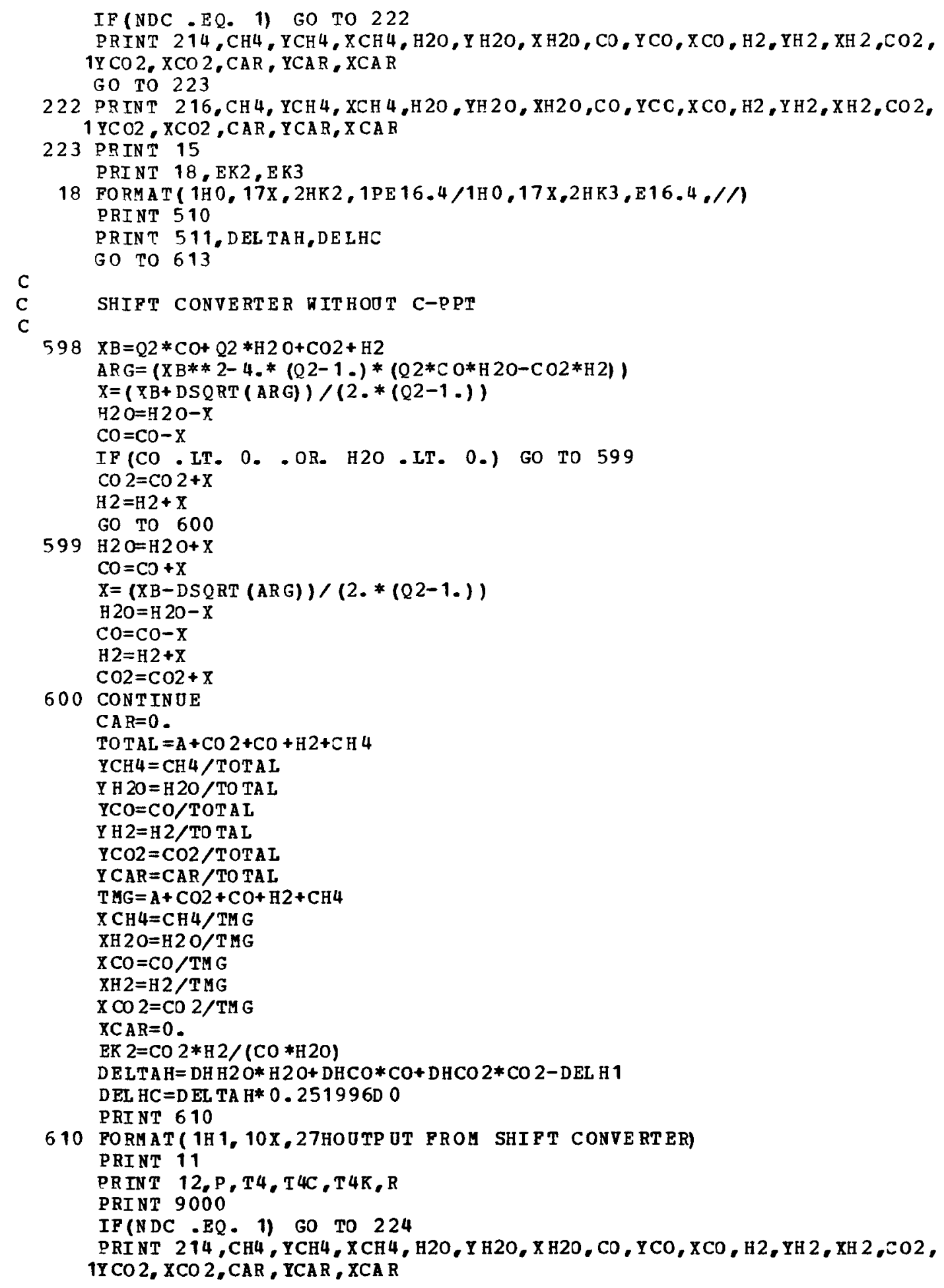




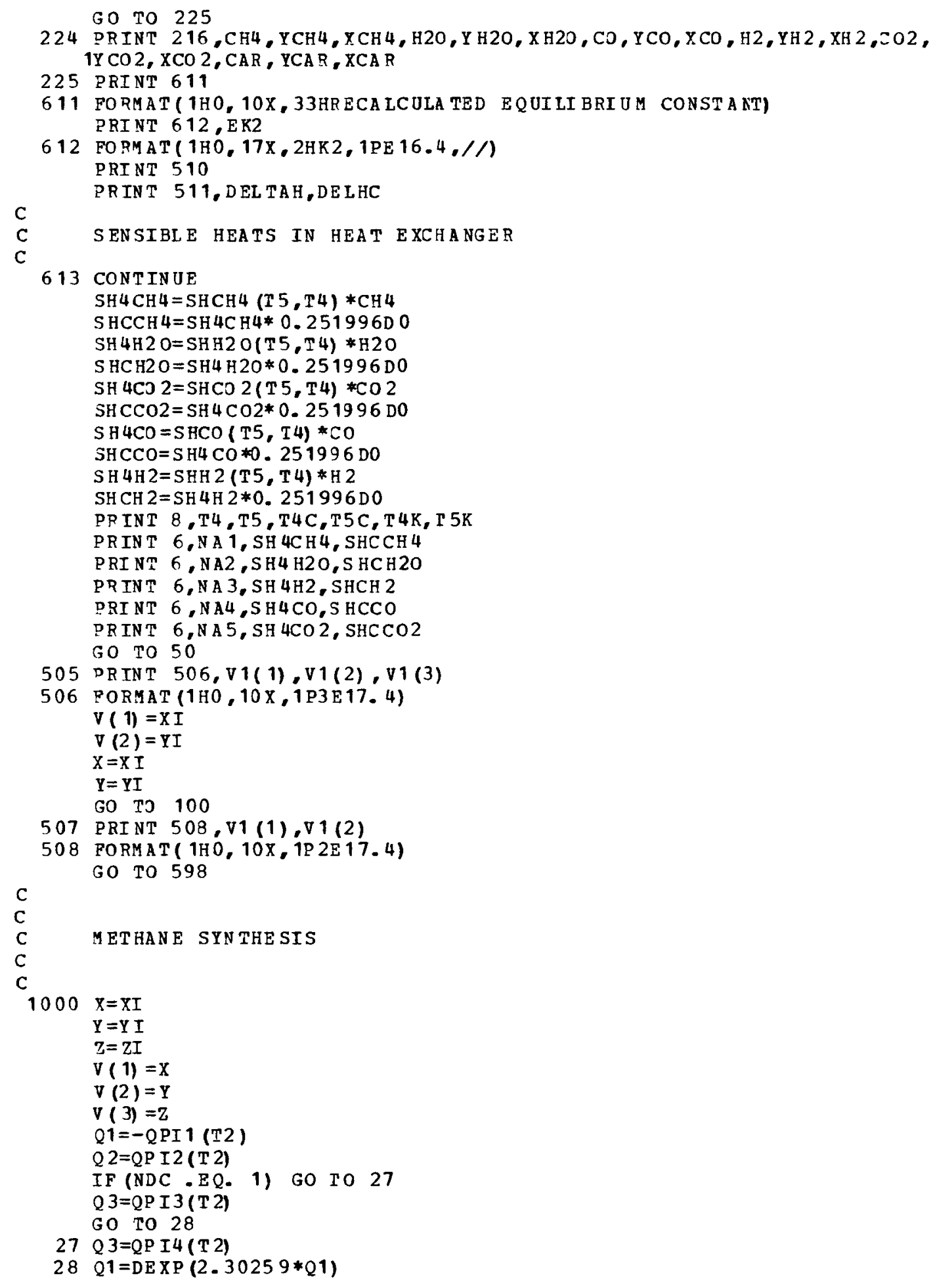




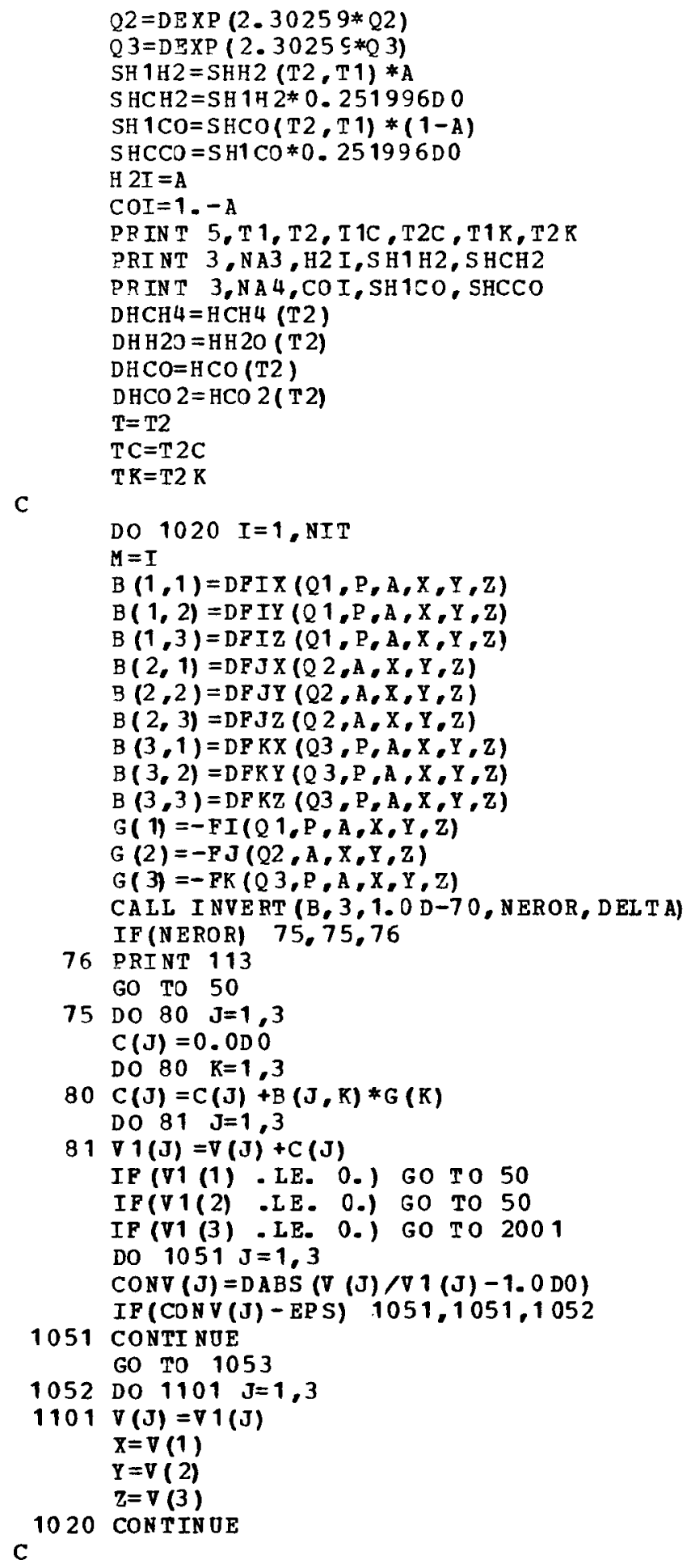




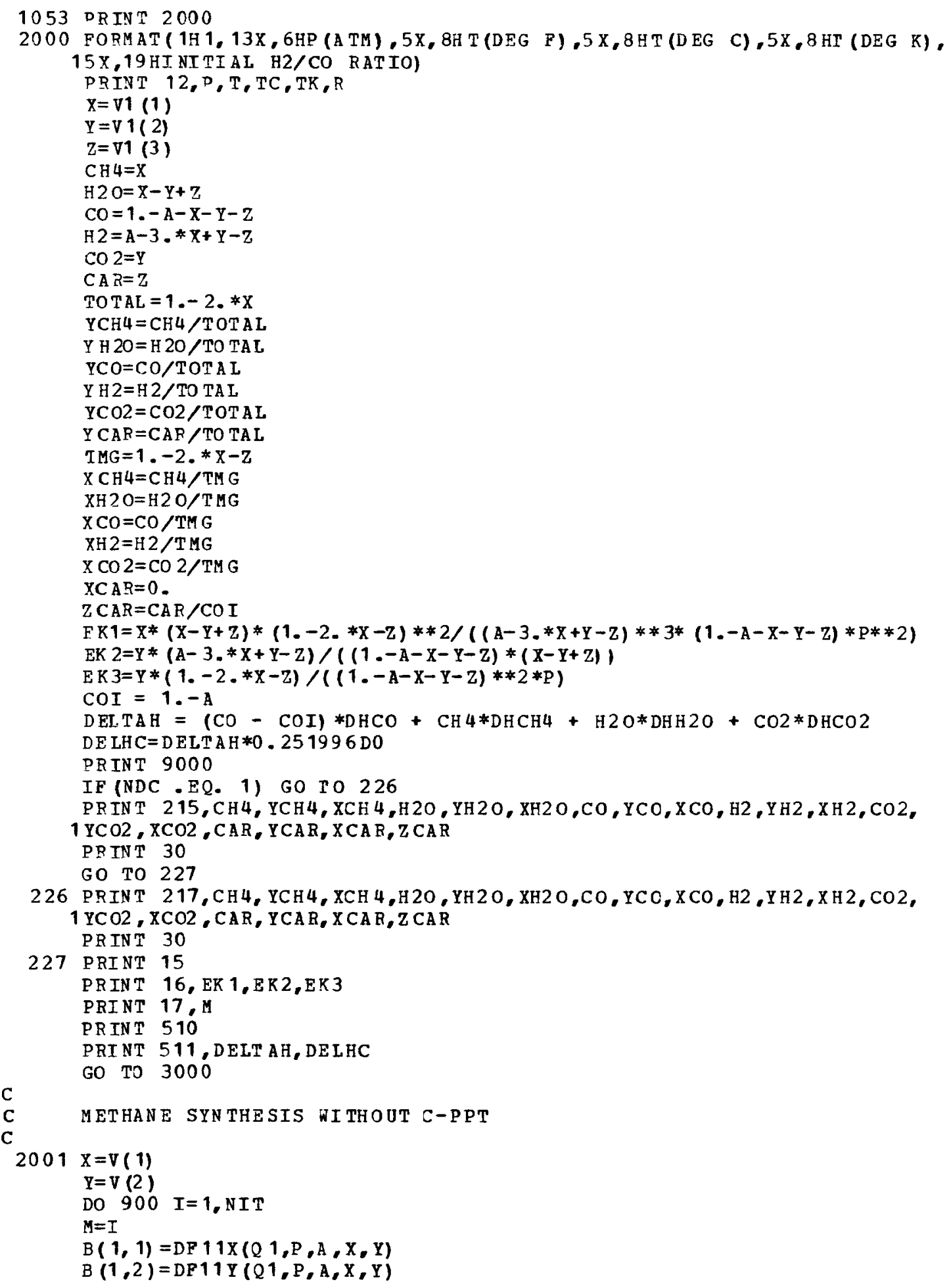




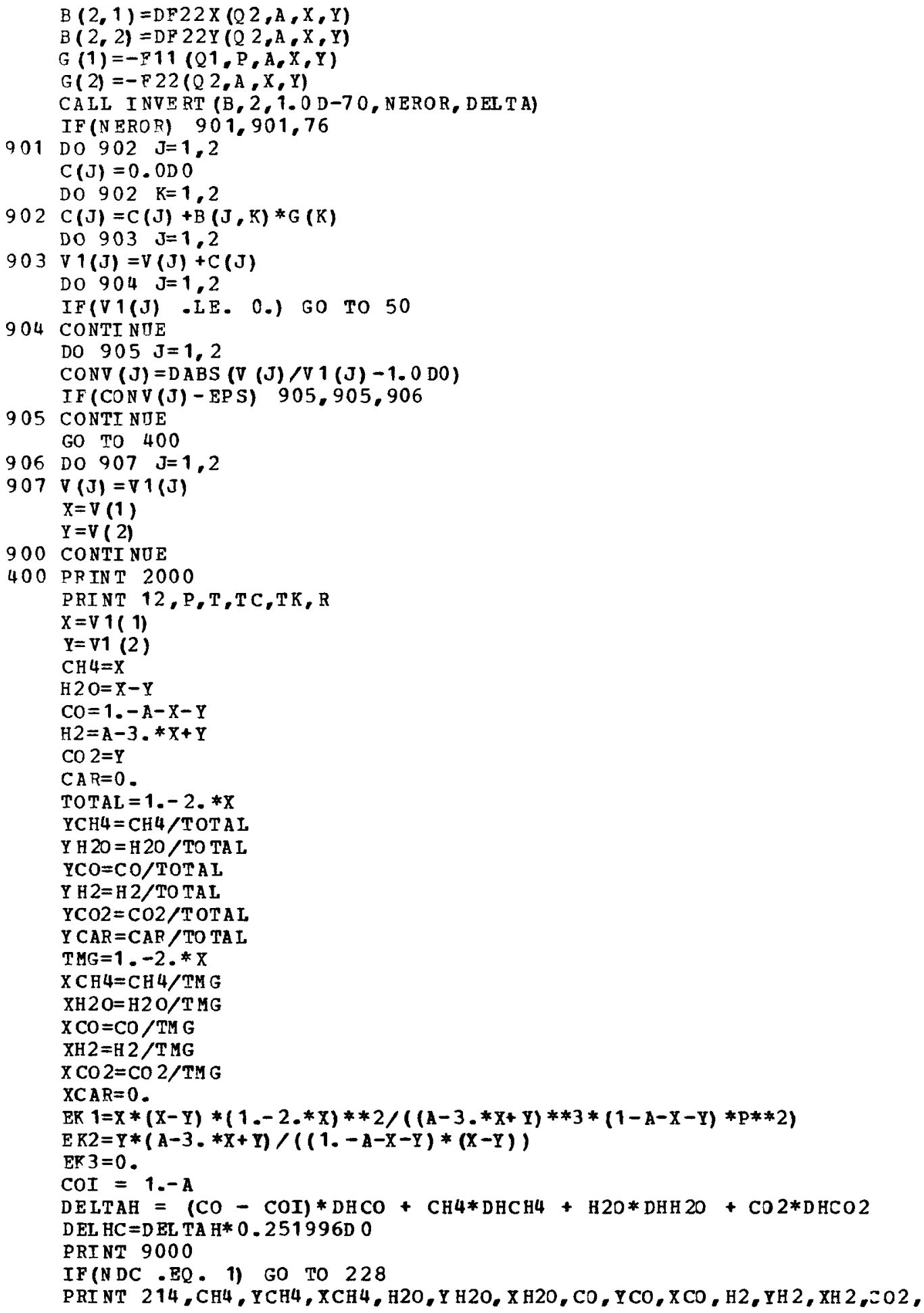




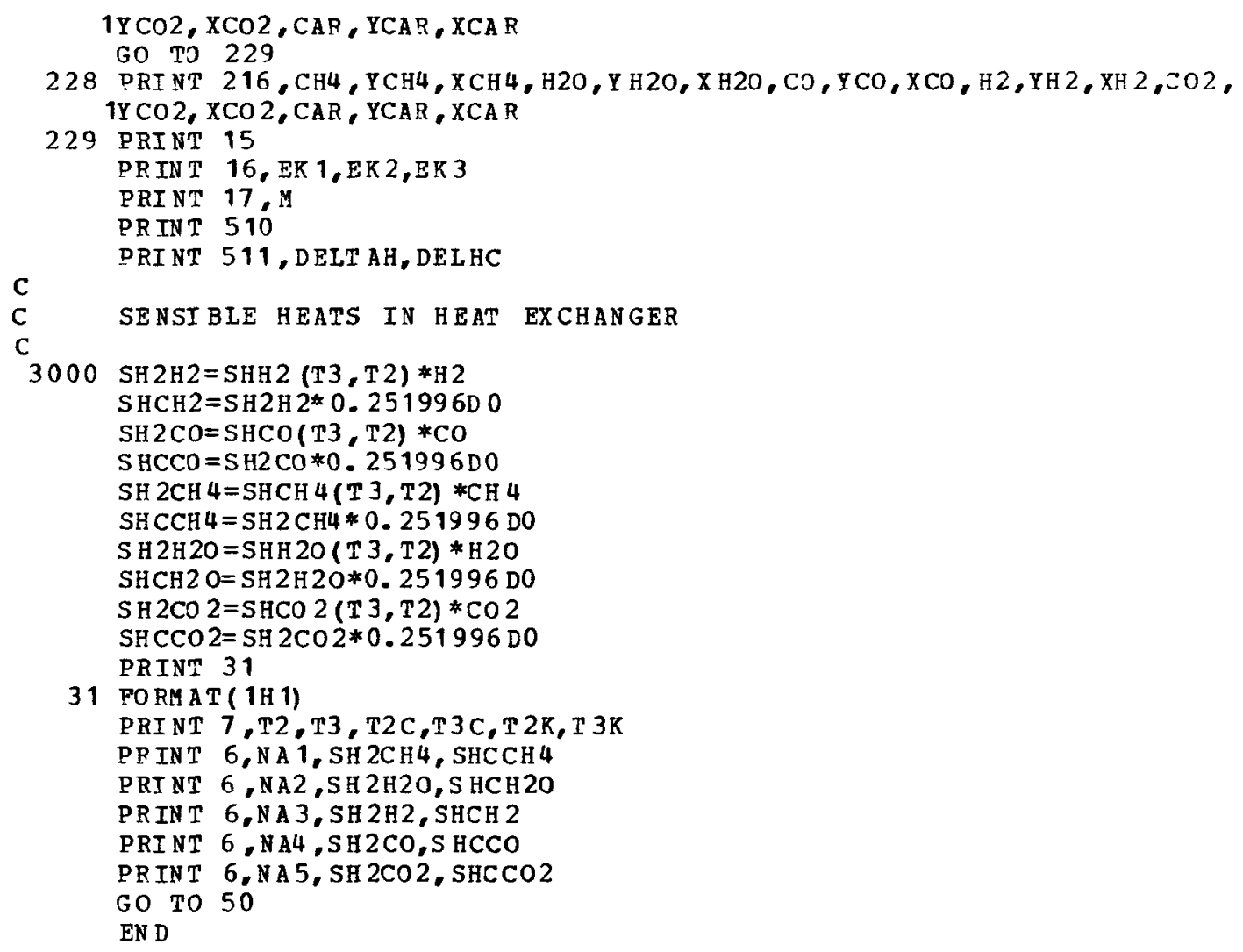


SUBRO UTINE INVERT (A, N, EPS, NEROR,DEITA)

DOUBLE PRECISION A, $\Psi$, W, DELT A, C, B, EPS

DIM EN SION A $(3,3), B(3), C(3), L Z(3)$

$D E L T A=1.0 \mathrm{DO}$

$N E R O R=0$

DO $10 \mathrm{~J}=1, \mathrm{~N}$

0050

$10 \mathrm{LZ}(\mathrm{J})=\mathrm{J}$

DO $20 \quad I=1, N$

$\mathrm{K}=\mathrm{I}$

$P=A(I, I)$

$\mathrm{L}=\mathrm{I}-1$

$\mathrm{I} P=\mathrm{I}+1$

IF (N-IP) $14,11,11$

0060

0070

0080

0100

0110

0120

11 DO $13 \mathrm{~J}=\mathrm{LP}, \mathrm{N}$

$\mathrm{H}=\mathrm{A}(\mathrm{I}, \mathrm{J})$

IF (DABS (W) - DAB S (Y) ) $13,13,12$

0130

0140

$12 K=J$

$\mathrm{Y}=\mathrm{W}$

0160

0170

13 CONTI NOE

14 DELTA = DEL TA*Y

DO $15 \mathrm{~J}=1, \mathrm{~N}$

$C(J)=A(J, K)$

0180

$A(J, K)=A(J, I)$

$A(J, I)=-C(J) / Y$

$A(I, J)=A(I, J) / Y$

$15 B(J)=A(I, J)$

$A(I, I)=1.0 \mathrm{DO} / \mathrm{Y}$

$\mathrm{J}=\mathrm{LZ}$ ( I)

$\mathrm{IZ}(\mathrm{I})=\mathrm{LZ}(\mathrm{K})$

$\mathrm{LZ}(\mathrm{K})=\mathrm{J}$

Do $19 \mathrm{~K}=1, \mathrm{~N}$

$\operatorname{IF}(\mathrm{I}-\mathrm{K}) 16,19,1 \mathrm{E}$

16 DO $18 \mathrm{~J}=1, \mathrm{~N}$

IF (I-J) $17,18,17$

$17 A(K, J)=A(K, J)-B(J) * C(K)$

18 CONTINUE

19 CONTIN UE

20 CONTI NUE

IF (DABS (DEL TA) - EP S) $80,80,81$

80 NE ROR=1

GO TO 82

81 DO $200 \quad I=1, N$

$I F(I-L Z$ (I) $100,200,100$

$100 \mathrm{~K}=\mathrm{I}+1$

IF (I-N) $800,200,200$

800 DO $500 \mathrm{~J}=\mathrm{K}, \mathrm{N}$

IF (I-LZ (J)) $500,600,500$

0200

0210

0220

0230

0240

0260

0270

0280

0290

0300

0310

0320

0330

0340

0350

0360

$600 \mathrm{M}=\mathrm{LZ}(\mathrm{I})$

IZ (I) $=\operatorname{IZ~(J)~}$

$\mathrm{LZ}(\mathrm{J})=\mathrm{M}$

DE LTA $=-D E L T A$

DO $700 \mathrm{~L}=1, \mathrm{~N}$

$C(I)=A(I, I)$

$A(I, L)=A(J, L)$

$700 \mathrm{~A}(\mathrm{~J}, \mathrm{~L})=\mathrm{C}(\mathrm{L})$

500 CONTIN UE

200 CONTI NUE

82 RETURN

0370

0380

0390

0400

0410

0420

0430

0440

0450

0460

0470

0480

0490

0500

0510 
ORNL -5225

Dist. Category UC-4

INTERNAL DISTRIBUTION

1-3. Central Research Library

4. ORNL - Y-12 Technical Library Document Reference Section

5-6. Laboratory Records Department

7. Laboratory Records, ORNL R.C.

8. C. F. Baes

9. C. E. Bamberger

10. C. J. Collins

11. F. L. Culler

12. A. S. Dworkin

13. L. M. Ferris

14. W. R. Gambill

15. R. F. Hibbs

16. 0. L. Keller

17-36. M. H. Lietzke

37. W. L. Marshal1

38. R. E. Mesmer
39. H. Postma

40. D. M. Richardson

41. M. W. Rosenthal

42. M. J. Skinner

43-47. G. P. Smith

48. R. A. Strehlow

49. R. W. Stoughton

50. I. L. Thomas

51. A. Zucker

52. Mary L. Good (Advisory Committee)

53. Glen E. Gordon (Advisory Committee)

54. Edward A. Mason (Advisory Committee)

55. Ernest Wenkert (Advisory Committee)

EXTERNAL DISTRIBUTION

56. Research and Technical Support Division, ERDA, P. O. Box 62, Oak Ridge, TN 37830

57-242. Given distribution as shown in TID-4500 under Chemistry category (25 copies - NTIS) 